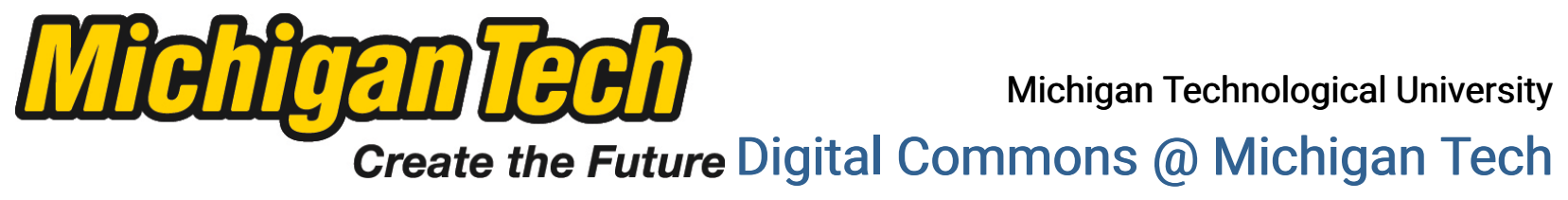

\title{
LOW IMPACT DEVELOPMENT (LID) OPPORTUNITIES IN THE DISTRICT OF LAMÚD, PERÚ: A STUDY OF HYDROLOGY, COSTS AND MAINTENANCE OF APPROPRIATE STORMWATER BEST MANAGEMENT PRACTICES (BMPS)
}

Olga M. Cano

Michigan Technological University

Follow this and additional works at: https://digitalcommons.mtu.edu/etds

Part of the Environmental Engineering Commons

Copyright 2015 Olga M. Cano

\section{Recommended Citation}

Cano, Olga M., "LOW IMPACT DEVELOPMENT (LID) OPPORTUNITIES IN THE DISTRICT OF LAMÚD, PERÚ: A STUDY OF HYDROLOGY, COSTS AND MAINTENANCE OF APPROPRIATE STORMWATER BEST MANAGEMENT PRACTICES (BMPs)", Master's Thesis, Michigan Technological University, 2015. https://doi.org/10.37099/mtu.dc.etds/953

Follow this and additional works at: https://digitalcommons.mtu.edu/etds

Part of the Environmental Engineering Commons 
LOW IMPACT DEVELOPMENT (LID) OPPORTUNITIES IN THE DISTRICT OF LAMÚD, PERÚ: A STUDY OF HYDROLOGY, COSTS AND MAINTENANCE OF APPROPRIATE STORMWATER BEST MANAGEMENT PRACTICES (BMPS).

By

Olga M. Cano

\begin{abstract}
A THESIS
Submitted in partial fulfillment of the requirements for the degree of MASTER OF SCIENCE

In Environmental Engineering
\end{abstract}

MICHIGAN TECHNOLOGICAL UNIVERSITY 2015

(C) 2015 Olga M. Cano 
This thesis has been approved in partial fulfillment of the requirements for the Degree of MASTER OF SCIENCE in Environmental Engineering.

Department of Civil and Environmental Engineering

Thesis Co-Advisor: Dr. Brian Barkdoll

Thesis Co-Advisor: Dr. Blair Orr

Committee Member: Dr. Kari Henquinet

Department Chair: Dr. David Hand 
"You must be the change

you wish to see in the world." - Mahatma Ghandi 


\section{Table of Contents}

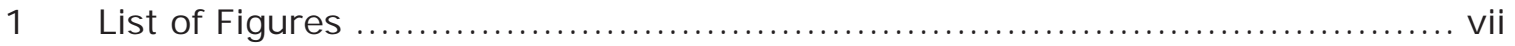

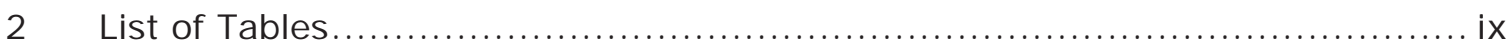

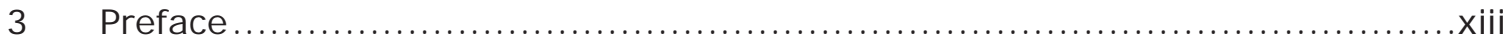

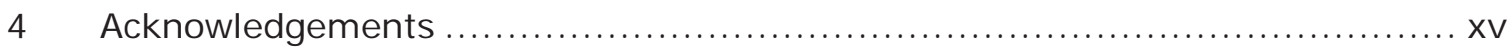

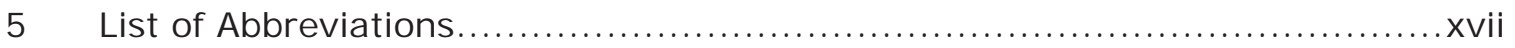

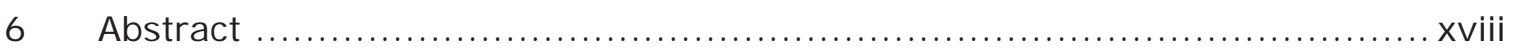

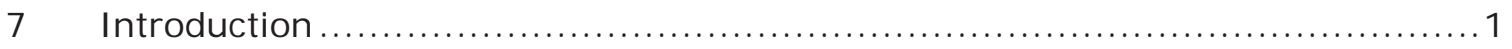

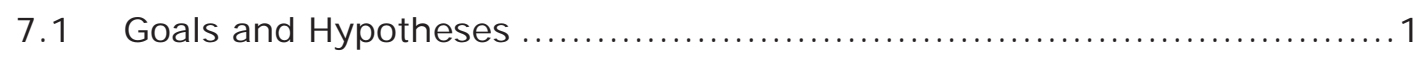

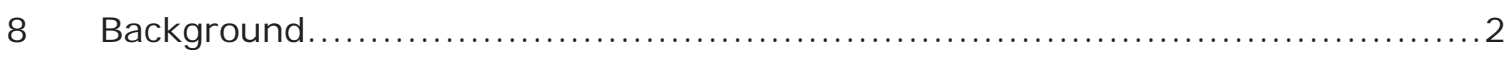

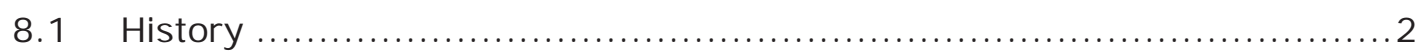

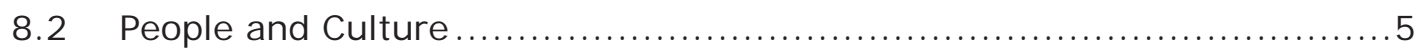

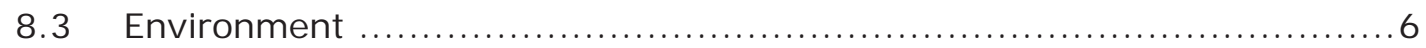

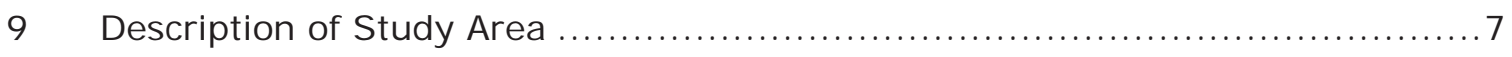

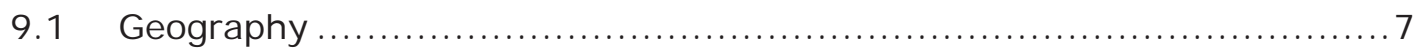

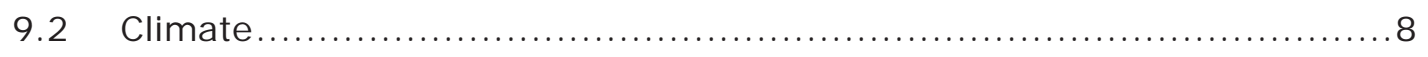

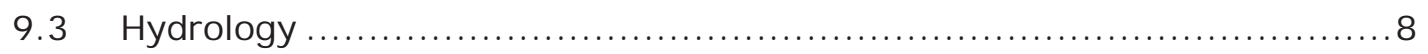

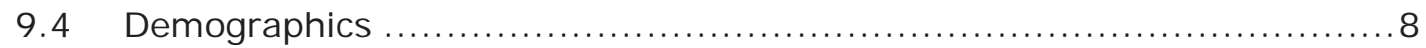

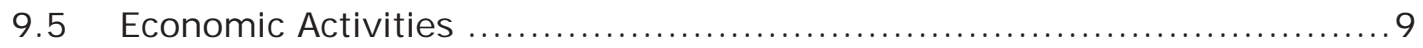

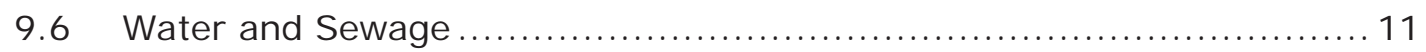

9.7 Urban Stormwater Management in Developing Countries ............... 16 
9.8 Low Impact Development

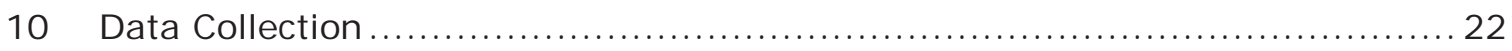

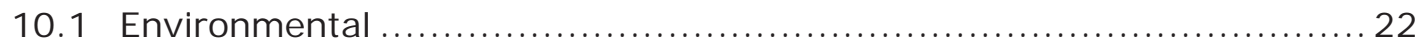

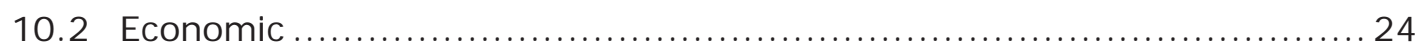

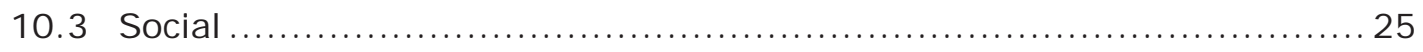

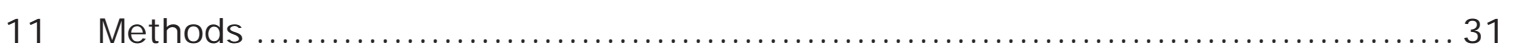

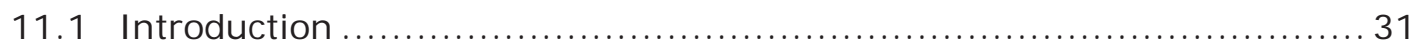

11.2 SWMM 5.1 EPA Hydraulic Model ..................................... 32

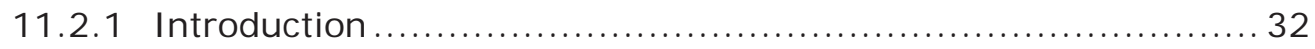

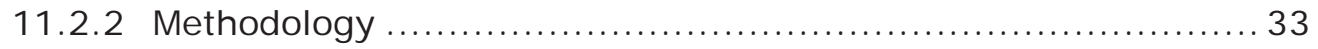

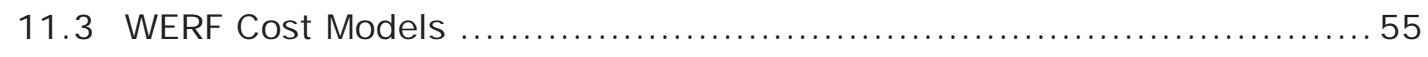

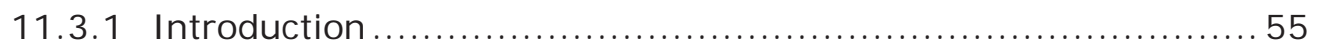

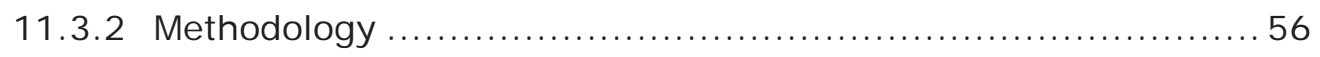

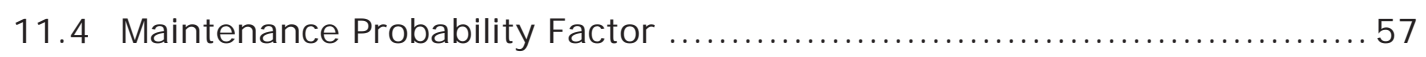

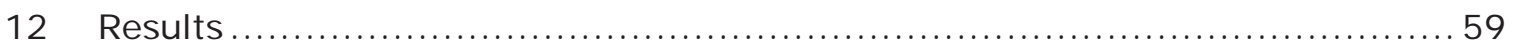

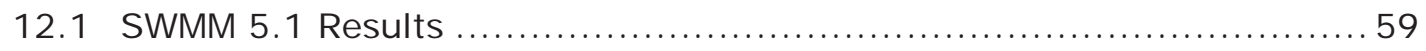

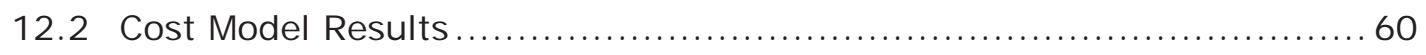

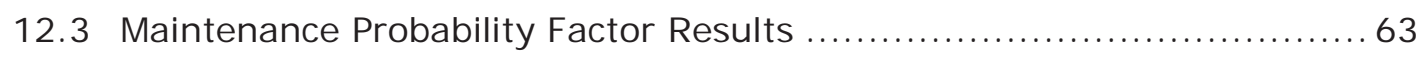

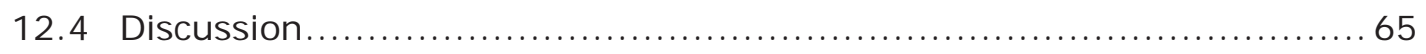

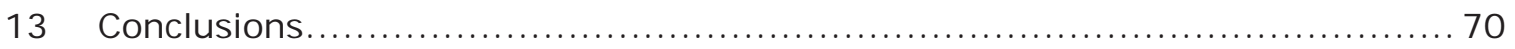

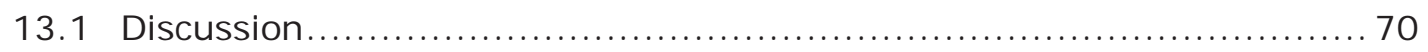

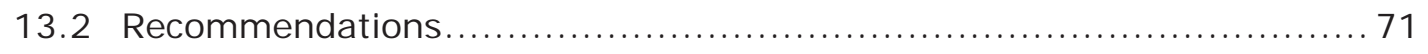

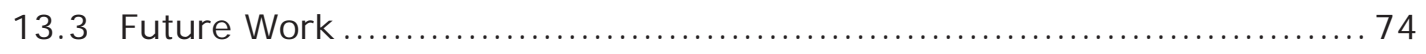

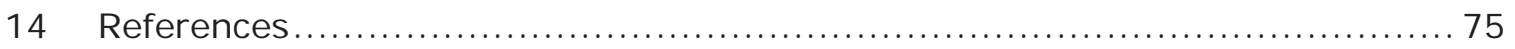




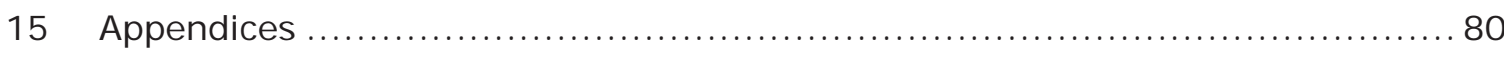

15.1 Appendix A: Chachapoyas Rainfall Data ............................ 80

15.2 Appendix B: LID BMPs Identification Diagram per case $\ldots \ldots \ldots \ldots \ldots \ldots \ldots 2$

15.3 Appendix C: LID BMPs Areas per Case ................................ 92

15.4 Appendix D: Maintenance Probability Factor (MPF) Tables ............. 104

15.5 Appendix E: SWMM 5.1 Runoff Results for all Cases .................. 111

15.6 Appendix F: SWMM 5.1 Detailed Results by Case $\ldots \ldots \ldots \ldots \ldots \ldots \ldots \ldots \ldots \ldots \ldots \ldots \ldots$

15.7 Appendix G: Tables of Capital and Maintenance Cost .................. 125

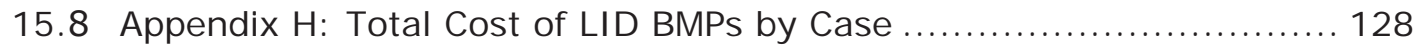

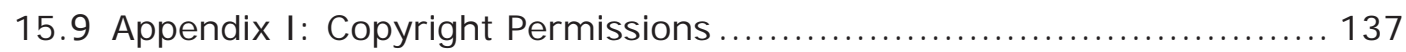




\section{List of Figures}

Figure 3.1 Author during a water system inspection........................... xiv

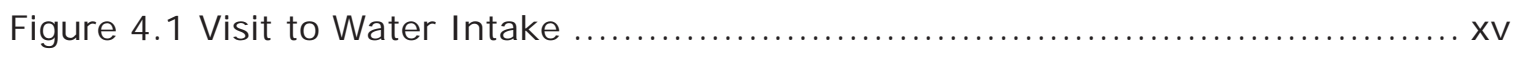

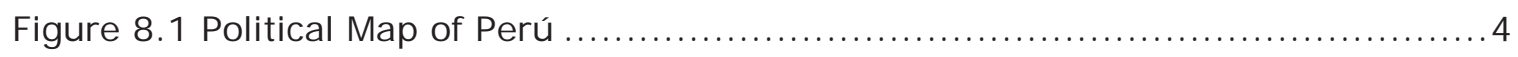

Figure 9.1 Map of Province of Luya with boundaries and location of districts ......... 7

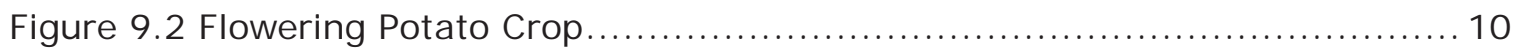

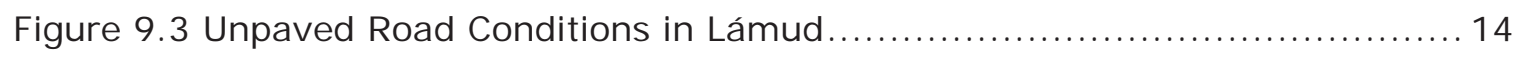

Figure 9.4 Paved Road in Lámud with Stormwater Management System ............. 14

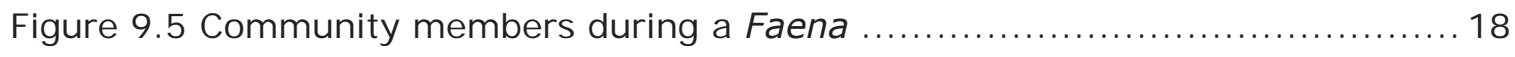

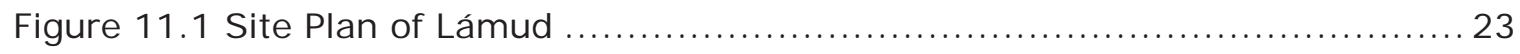

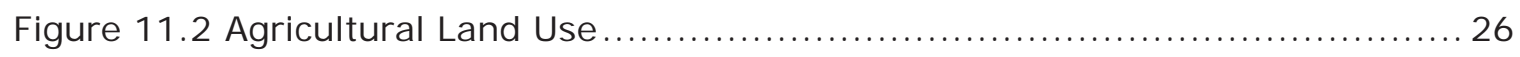

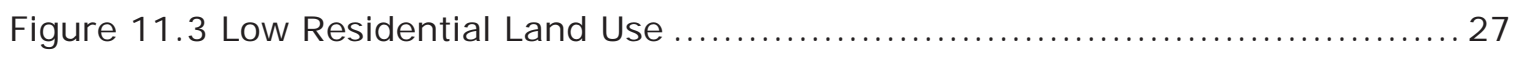

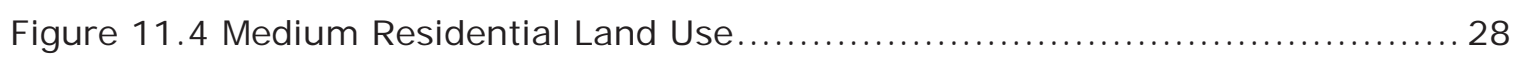

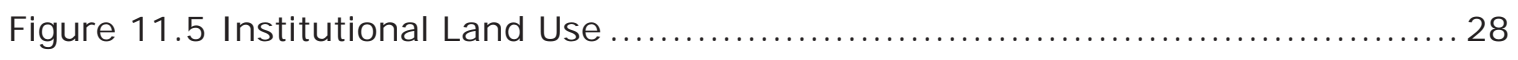

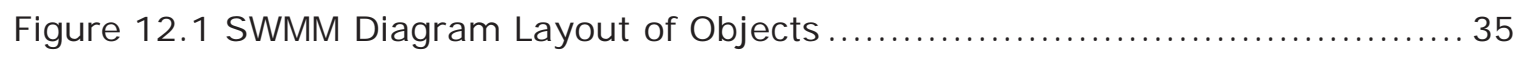

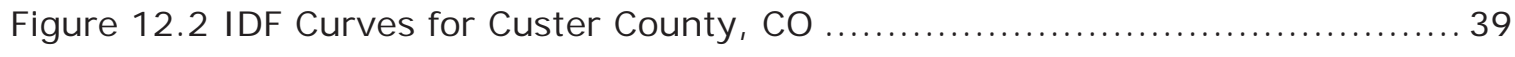

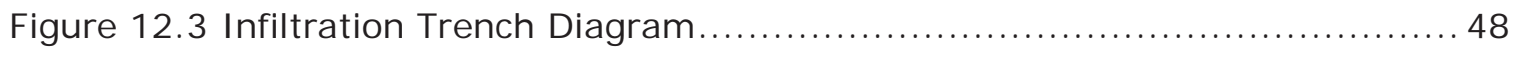


Figure 12.4 Vegetated Swale Diagram

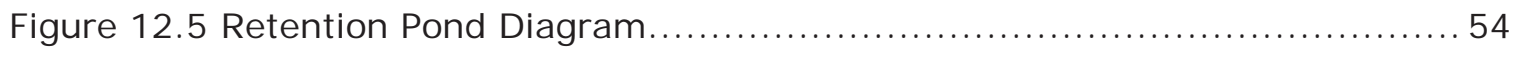

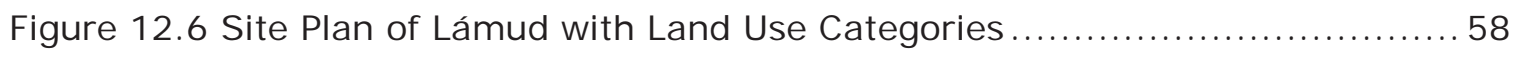

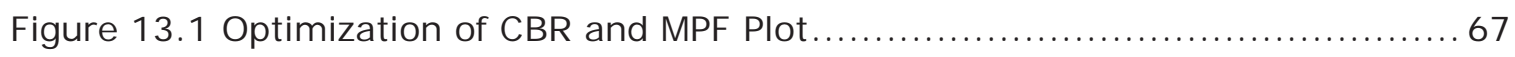

Figure 13.2 Optimization of MPF and CBR for Cases $7,8,9$ and $10 \ldots \ldots \ldots \ldots \ldots \ldots 67$

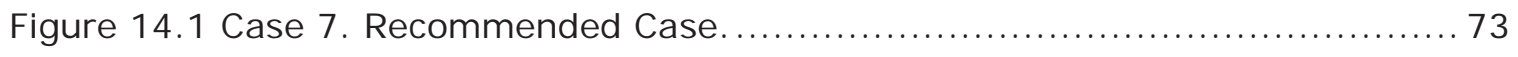

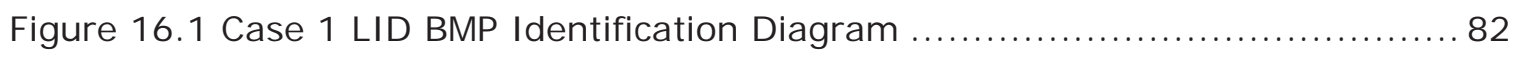

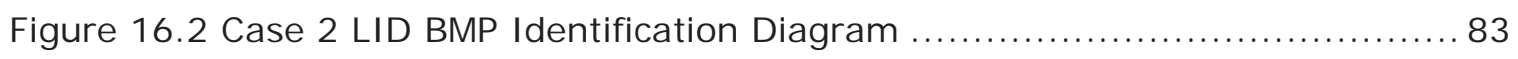

Figure 16.3 Case 3 LID BMP Identification Diagram ........................... 84

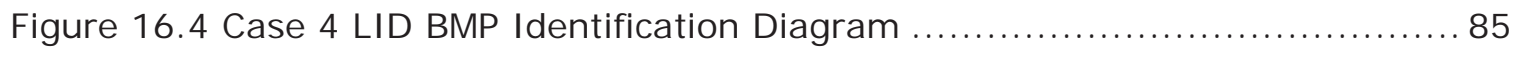

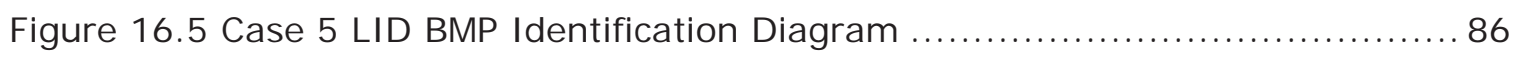

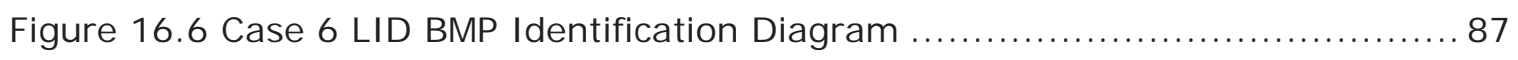

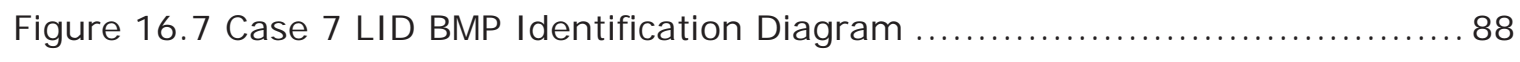

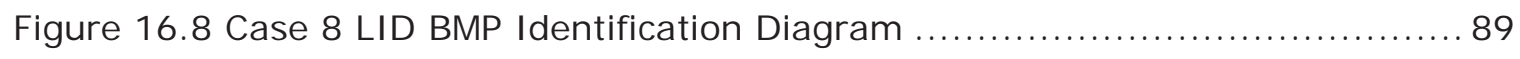

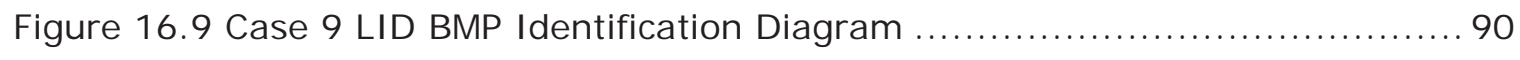

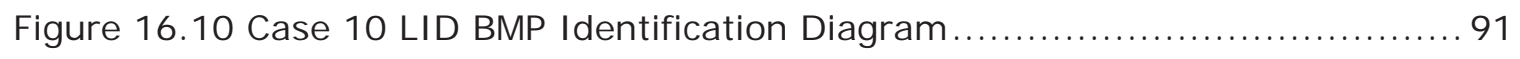




\section{List of Tables}

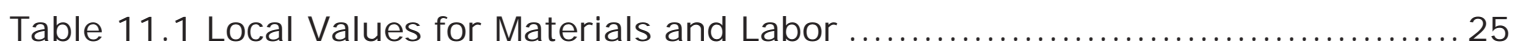

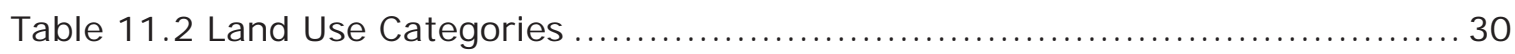

Table 12.1 Subcathment Characteristics and Sizing of LID BMPS $\ldots \ldots \ldots \ldots \ldots \ldots \ldots \ldots \ldots$

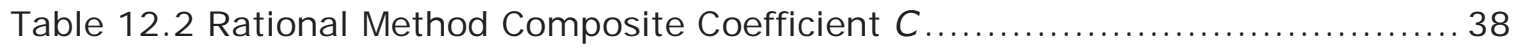

Table 12.3 Common Values for Subcatchment Properties $\ldots \ldots \ldots \ldots \ldots \ldots \ldots \ldots \ldots \ldots . \ldots 1$

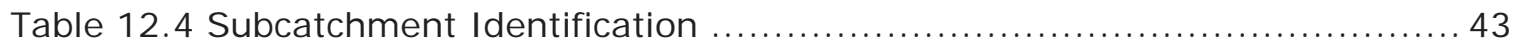

Table 12.5 Common Values for J unctions and Conduits $\ldots \ldots \ldots \ldots \ldots \ldots \ldots \ldots \ldots \ldots . \ldots 4$

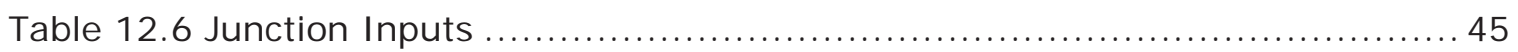

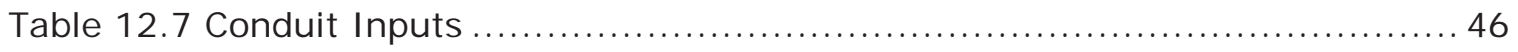

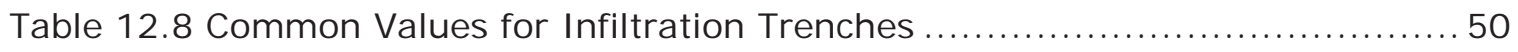

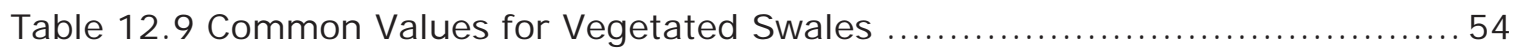

Table 13.1 Ranking of Cases Based on Proximity to Natural Case $\ldots \ldots \ldots \ldots \ldots \ldots \ldots . \ldots 6$

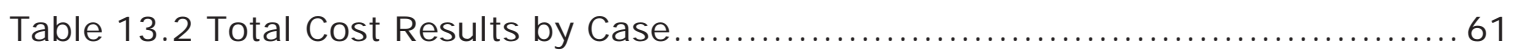

Table 13.3 LID BMP Maintenance Probability Factor Ranking $\ldots \ldots \ldots \ldots \ldots \ldots \ldots \ldots \ldots . \ldots \ldots$

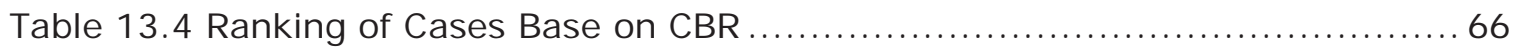

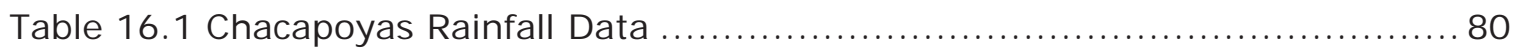


Table 16.2 Chachapoyas Rainfall Data (continued from Table 16.1)

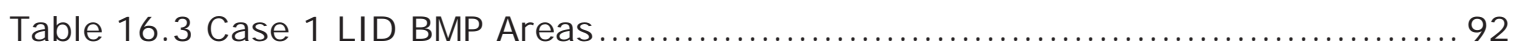

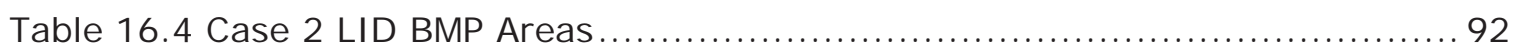

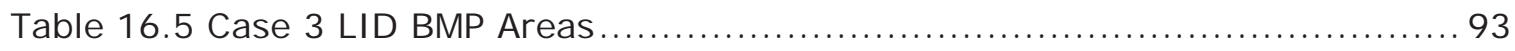

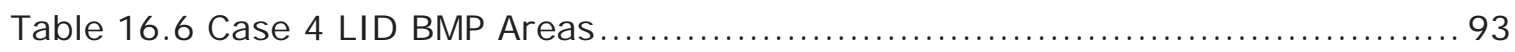

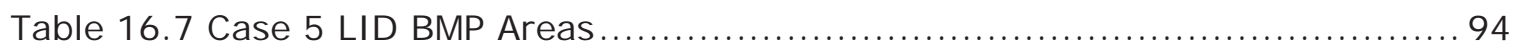

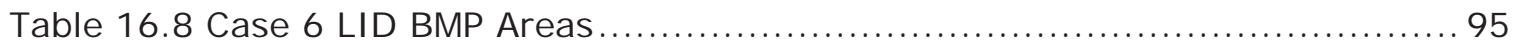

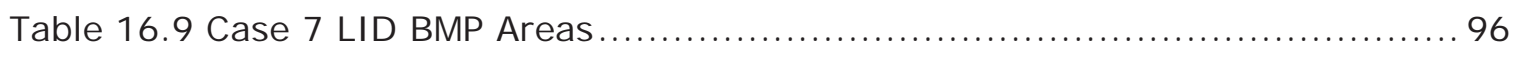

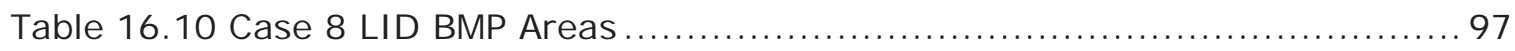

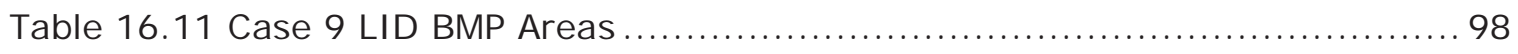

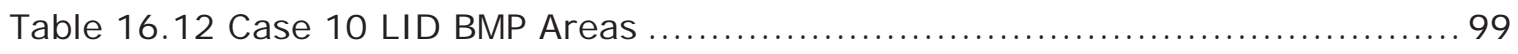

Table 16.13 Case 1 MPF Values per Subcatchment and Average per Case .......... 104

Table 16.14 Case 2 MPF Values per Subcatchment and Average per Case .......... 104

Table 16.15 Case 3 MPF Values per Subcatchment and Average per Case .......... 105

Table 16.16 Case 4 MPF Values per Subcatchment and Average per Case .......... 105

Table 16.17 Case 5 MPF Values per Subcatchment and Average per Case .......... 106

Table 16.18 Case 6 MPF Values per Subcatchment and Average per Case ......... 107

Table 16.19 Case 7 MPF Values per Subcatchment and Average per Case .......... 108 
Table 16.20 Case 9 MPF Values per Subcatchment and Average per Case 109

Table 16.21 Case 10 MPF Values per Subcatchment and Average per Case......... 110

Table 16.22 SWMM Runoff Results per Subcatchment

Table 16.23 SWMM Runoff Results per Subcatchment (Continued from Table $16.22)$

Table 16.24 Natural Case SWMM Results 113

Table 16.25 Road Case SWMM Results 114

Table 16.26 Case 1 SWMM Results 115

Table 16.27 Case 2 SWMM Results 116

Table 16.28 Case 3 SWMM Results 117

Table 16.29 Case 4 SWMM Results 118

Table 16.30 Case 5 SWMM Results 119

Table 16.31 Case 6 SWMM Results 120

Table 16.32 Case 7 SWMM Results 121

Table 16.33 Case 8 SWMM Results 122

Table 16.34 Case 9 SWMM Results 123

Table 16.35 Case 10 SWMM Results 124

Table 16.36 Detailed Costs for Infiltration Trenches 125

$x i$ 
Table 16.37 Detailed Costs for Vegetated Swales

Table 16.38 Detailed Costs for Retention Ponds

Table 16.39 Case 1 Total Cost by Subcatchment 128

Table 16.40 Case c Total Cost by Subcatchment 128

Table 16.41 Case 3 Total Cost by Subcatchment 129

Table 16.42 Case 4 Total Cost by Subcatchment 130

Table 16.43 Case 5 Total Cost by Subcatchment 131

Table 16.44 Case 6 Total Cost by Subcatchment 132

Table 16.45 Case 7 Total Cost by Subcatchment 133

Table 16.46 Case 8 Total Cost by Subcatchment 134

Table 16.47 Case 9 Total Cost by Subcatchment 135

Table 16.48 Case 10 Total Cost by Subcatchment 136 


\section{Preface}

The author served as a Peace Corps Volunteer in Perú under the program of Water, Sanitation and Hygiene for two years as part of the Peace Corps Masters International (PCMI) Program at Michigan Technological University. During this time she was highly involved with the Provincial Municipality of Luya located in the capital of Lámud. Her efforts focused on the development of a Technical Municipal Area whose main purpose was to provide technical, educational and economic support for water and sanitation efforts throughout the province of Luya. The greatest challenges were the quick turnaround of staff and other political interests which influenced the allocation of funds. Within the municipality she had the opportunity to work close with Mr. Juan Santillan - water operator - who was highly knowledgeable of the water and sanitation issues and opportunities in the community. In coordination with the municipality, the local health post and community groups she trained water operators in the proper use and operation of water systems as well as activities focused on healthy hygiene practices such as hand washing, household water treatment and the proper use of latrines.

Of great success was the implementation of improved cookstoves constructed in households to improve indoor air quality. 


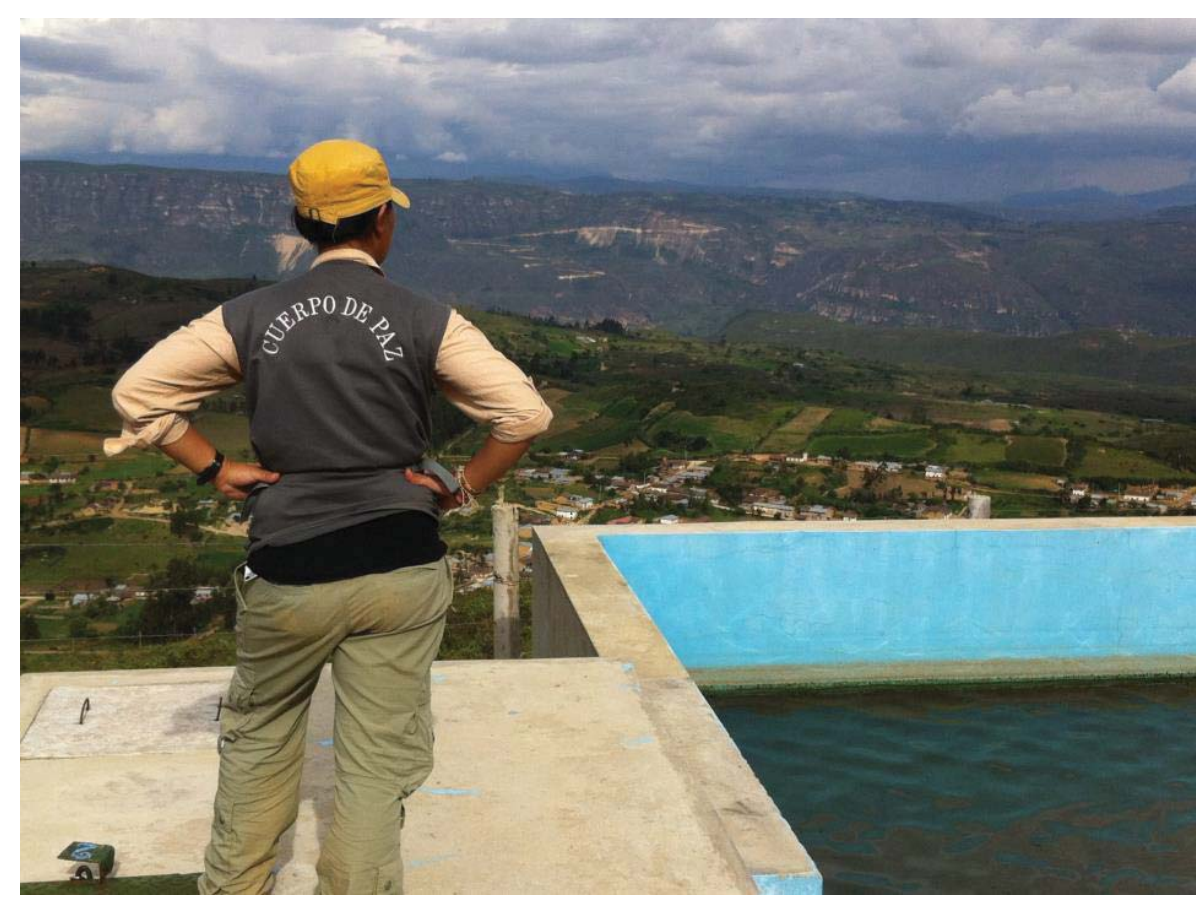

Figure 3.1 Author during a water system inspection

Location: Luya, Perú | Photo By: Ian P. Toohey (Toohey 2012)

Given her background in architecture and interest in sustainable urban development and human centered design, she identified the challenges the community of Lámud was having with their stormwater management practices. After experiencing the first rainy season, it became obvious that the poor stormwater management was effecting landowners as their crops and homes flooded. However, it became apparent that the population sector which was most vulnerable to these impacts were those who depended on their crops to support themselves and their families and thus placing their livelihoods at risk. These circumstances triggered the effort to identify opportunities to implement Low Impact Development (LID) Best Management Practices (BMPs) for stormwater management. With support from the Municipalidad Provincial de Luya-Lamud (Provincial Municipaity of Luya-Lamud) and their team under the Instituto Vial Provincial (Provicial Institute of Roads) she was able to collect data and carry out this study. 


\section{Acknowledgements}

The most sincere gratitude goes out to my thesis co-advisors Dr. Brian Barkdoll, Dr. Kari Henquinet and Dr. Blair Orr, who have offered ongoing support throughout my time at Michigan Technological University and during my time as a Peace Corps Volunteer in Perú. Their technical knowledge and understanding of the challenges encountered while carrying out research abroad have proved to be invaluable. Thank You.

To Jorge Izaguirre, Water Sanitation and Hygiene Peace Corps Perú APCD, whose knowledge of Perúvian customs and politics aided me in navigating the very complex system I was forced to work in.

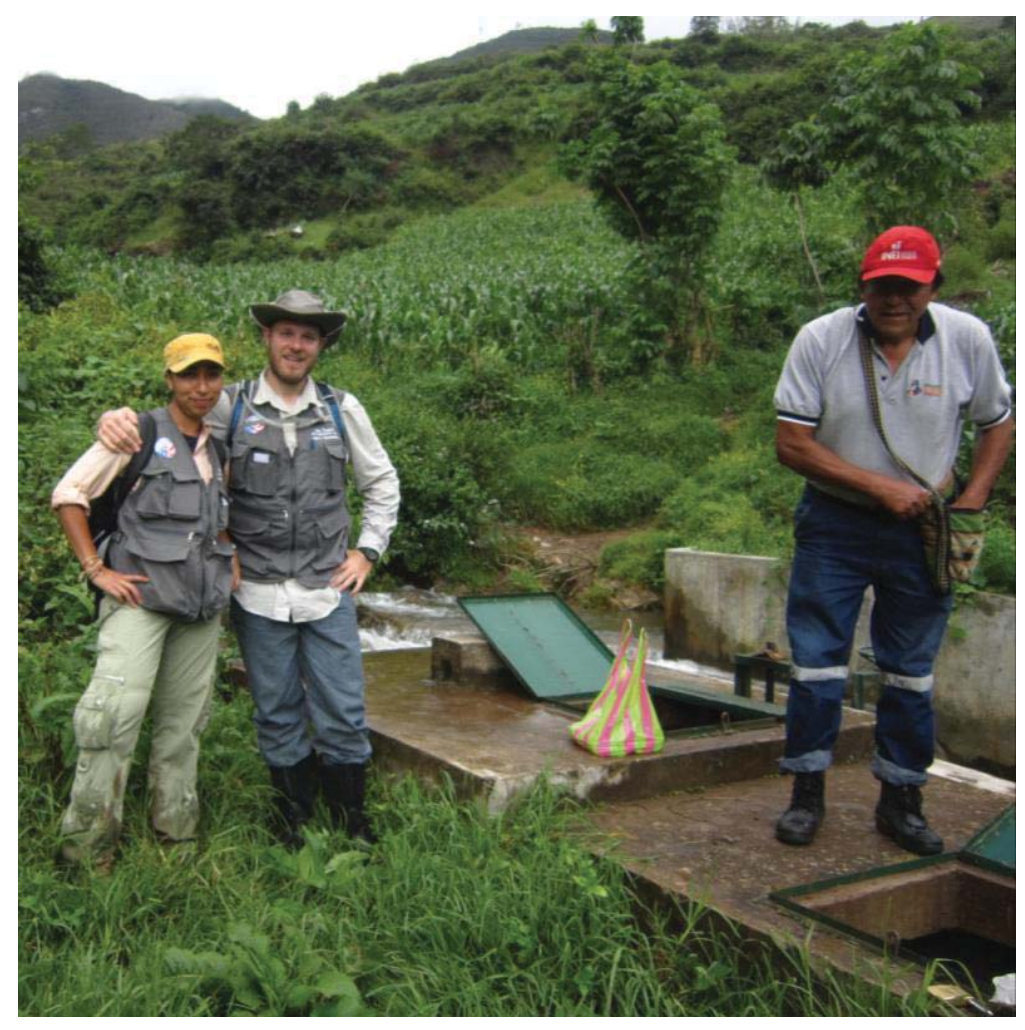

Figure 4.1 Visit to Water Intake

From left to right: Author, Ian P. Toohey and Don Juan Santillan (Cano 2012) 
Don Juan Santillan, Don Jose Cuipal Olivares and Don Teodocio Apolinares Grandes whom became key counterparts and supporters in all of my activities and projects during my time in Perú.

The Mori Urquia Family, who adopted me as a daughter during my two year stay at their home. All of the friends and acquaintances I made during my time in Lámud, as they were key in making me feel home while I was away from home.

A special thank you to my fellow RPCV colleagues and friends Ian P. Toohey, P.E. and Dee Dee DeVuyst, for their generosity in sharing knowledge, resources and providing constructive criticism throughout this study.

To my family. A mis padres, Nestor e Irene, a mi hermana Marce, gracias por el apoyo incondicional que me ofrecen en cada uno de mis proyectos, decisiones y aventuras. Gracias por el sacrificio que han hecho para brindarnos un futuro mejor. Pero ante todo, gracias por enseñarme la importancia de ver el mundo tal como es con humildad y la audacia de imaginarlo como puede ser. Cada logro es de todos.

Finally, an immense amount of gratitude to Evan Anderson. Your experience and knowledge of working in a developing country helped me avoid many challenges. Your patience and empathy helped me get through the ones I encountered. We've beat the odds. Let's Do It! 


\section{List of Abbreviations}

BMP: Best Management Practice

CIRIA: Construction Industry Research and Information Association

CMS: Cubic Meters per Second

CRC: Cooperative Research Center

EPA: Environmental Protection Agency

EPS: Empresa Publica de Servicios (Plublic Service Provider)

SWMM: Stormwater Management Model

LID: Low Impact Development

NOAA: National Oceanic and Atmospheric Administration

NRCS: National Resources Conservation Service

SENAMHI: Servicio Nacional de Meteorologia Hidrolica del Perú

SUDS: Sustainable Urban Drainage System

WAAP: Water Access Awareness Program

WSUD: Water Sensitive Urban Design

WERF: Water Environment Research Foundation 


\section{Abstract}

The study aims at identifying opportunities to implement Low Impact Development (LID) Best Management Practices (BMPs) for stormwater management, in the District of Lámud, Perú. Other studies have noted the importance of appropriate stormwater management as part of urban development in developing countries.

Environmental, economic and social aspects were analyzed to identify the most appropriate case. Stormwater Management Model (SWMM) 5.1, was used to obtain runoff results. Ten case scenarios were set up with LID BMP combinations of infiltration trenches, vegetated swales, and retention ponds. Water Environment Research Foundation (WERF) life cost models were used as a reference to calculate initial and maintenance costs. A Cost Benefit Ratio (CBR) was developed to identify the most cost effective case. Data on land use was collected and a Maintenance Probability Factor (MPF) developed to identify the likelihood of maintenance.

Case 7 was recommend as it optimizes both CBR and MPF. 


\section{Introduction}

\subsection{Goals and Hypotheses}

Climate change is a global issue being experienced at various scales throughout the world. Flooding, as a result of climate change, has social and economic impacts that destabilizes communities and becomes an obstacle to development. Through the continuous use of conventional storm water management systems, developing communities are losing out on the opportunity to implement storm water management practices that would decrease flooding events. As urbanization occurs in rural communities, land uses are altered resulting in larger impermeable areas within watersheds. This results in an increase of storm flow rates which in turn may result in flooding of receiving streams and rivers.

Low Impact Development (LID) techniques have started to become widely accepted as efficient stormwater management methods. These techniques facilitate the retention of runoff and aim to mimic pre-development hydrologic properties. Through strategic placement, LID systems are able to collect runoff from adjacent impervious surfaces (i.e., streets and buildings) and promote infiltration through pervious surfaces (i.e., swales, trenches and ponds). Furthermore, in some cases these systems may also treat runoff pollutants and recharge ground water aquifers (Holman-Dodds J.K. 2003).

Rural communities are some of the most vulnerable to climate change impacts, given that these extreme and rapid changes, as are flood events, threaten their shelter and agricultural systems, both of which rural communities depend on (Dasgupta 2014). 
In developing communities the cost of construction, operation and maintenance is key to the long-term durability of any technology. With this as a priority, infiltration trenches, vegetative swales and retention ponds have been chosen given the availability of materials in the area and their low level of required maintenance. Additionally, LID BMP systems are an appropriate technology for this type of setting, as their routine maintenance and operation does not require advanced technical skills. In the district of Lámud, a conventional stormwater management system has already been installed. The system routes excess runoff into nearby rivers making them more susceptible to flash floods. This study simulates various combinations of LID BMP systems, referred as cases, in a defined study area using the Environmental Protection Agency (EPA) Stormwater Management Model (SWMM) as a decision making tool. The hydrological impact of each of the cases is then compared in order to identify the most efficient combination of LID BMP systems.

Reducing the risk of flooding is of high priority in communities whose livelihoods depend the sustainability and protection of lands and environmental eco-systems. A study carried out in Bangladesh explains that those who are most vulnerable - the poor - are the same sector of the population who experience higher impacts by flooding incidents (Brouwer, et al. 2007). Equally as important is the need to maintain good public health standards through proper management of stormwater.

\section{Background}

\subsection{History}

Perú is best known for its Inca Empire established before the arrival of the Spaniards in 1531. The Inca Empire extended from northern Ecuador to central Chile and was 
centered in the city of Cuzco, Perú. Upon the arrival of the Spaniards, the wellestablished empire was diminished by disease, with the smallpox epidemic being the most prominent. Ultimately, the Incas were conquered by Spaniards, with Francisco Pizarro becoming Perú's conquistador. Pizarro is now idolized throughout the country and celebrated yearly. In 1533 Spaniards claimed Cuzco, the capital of the Inca Empire, and through the wealth of gold and silver found in the Andes sustained their power throughout this era (Crosby 1967).

Lima, today's capital of Perú, was founded by Pizarro in 1535 and through the colonial period (1820-1824) Lima was the most distinguished city in South America as it became the city the Spanish royals resided until the wars of independence. In today's Lima, street names and landmarks have become vivid remnants of this era (Crosby 1967).

Perú's independence was recognized by Spain in 1879. However, prior to this there had been various attempts at the nation's independence through the efforts of J osé de San Martín and Simón Bolivar. The battle of Ayacucho, led by the General Antonio J osé de Sucre, marks the defeat of the Spaniards and ending an era of Spanish rule in South America in 1824 (Crosby 1967).

After the nation's independence from Spain, Perú faced territorial conflicts with neighboring nations of Ecuador, Chile and Bolivia. The first was the invasion of Chile ending in a territorial settlement in 1883 known as the War of the Pacific. Then in 1941, Perú and Ecuador fought to establish territorial boundaries which historically has come to be referred to as the Rio Protocol. After various armed conflicts in 1981, 1995 and 1998 Perú and Ecuador finally came to an agreement and signed peace treaty defining their boundaries. Likewise, after a long period of conflicts with Chile the two 
countries came to a consensus in 1999 by implementing the last article of their 1929 border agreement (Crosby 1967).

Perú started to undergo an era of political turmoil in 1968 when General Juan Velasco Alvarado overthrew the then democratically elected President Fernando Belaunde Terry. General Velasco implemented country wide reforms within various industries including agriculture, fish meal, petroleum, banking and mining with the purpose to find socio-economic equality. The second phase of this reform came under the leadership of Francisco Morales Bérmudez as he continued the revolution and carried out efforts to restore the country's economy (Crosby 1967).

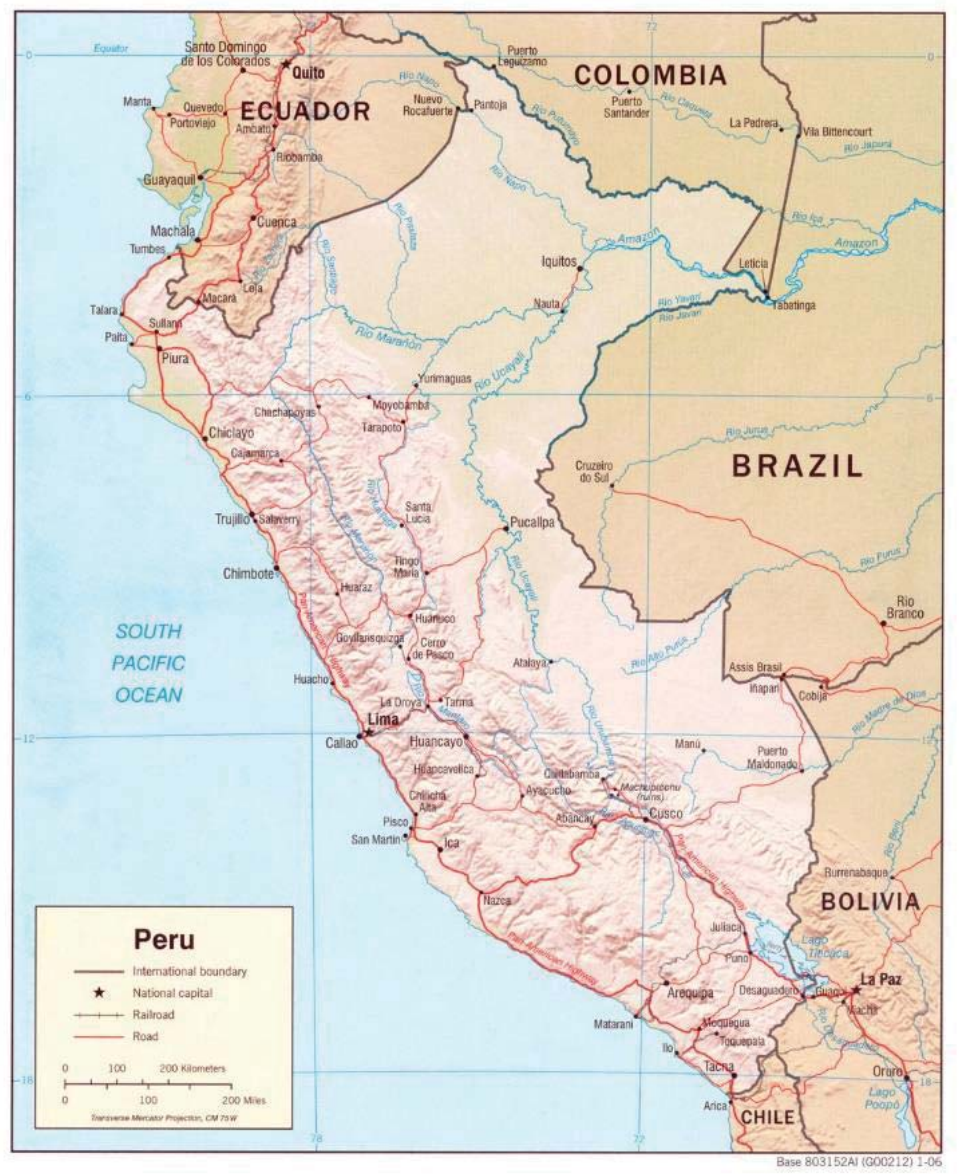

Figure 8.1 Political Map of Perú

Source: University of Texas (UT 2015) 
During the 80s the country went through a civil war, of which well-known revolutionary group The Shining Path obtained a dominance over many rural communities in the country. After much turmoil democratic election were held and in 1985 Alan Garcia Peréz became Perú's first elected president in 40 years (BBC News 2006).

During Garcia's government the local economy suffered an economic crisis reaching a $7,650 \%$ inflation rate. The country's crisis presented an ideal opportunity for the voters to take a chance on an unknown candidate. In 1990 Alberto Fujimori came into office and though he was not well known in the political arena, he was a promising candidate. Fujimori was able to bring inflation rates down to $139 \%$. He is also commended for the imprisonment of the Shining Path's leader (BBC News 2011). Despite all these achievements Fujimori was caught in a bribery scandal after his second election and was forced to step down and flee the country in 2000.

President Alejandro Toledo came into office in 2001. This administration was successful in taking the country through a steady economic growth making Perú the leading South American country in GDP growth rates from 2002 to 2005. Unfortunately, for this administration, the gain of economic growth was not reaching the neediest, making the president's popularity ratings decline (Peru politics: Toledo faces test of authority 2003). Due to this decline Toledo was not re-elected and was replaced by Perú's current president, President Ollanta Humala, who was sworn into office on July 28, 2011.

\subsection{People and Culture}

Perú is an ethnically diverse country with black, Japanese and Chinese in addition to indigenous and Europeans and a population of 29 million. About $70 \%$ of its population lives in urban and semi-urban areas. Lima, the capital, has a population of 8.9 million. 
Due to its diversity, the country has experienced ongoing social and political segregation of minorities. The mestizo culture, partially defined as Amerindians who have adopted the Hispanic culture, and the Andean cultures of the highlands and eastern side of the Andes have developed significant socioeconomic divides. Of all the minorities, Perúvians of Asian and European descent have made the most progress during the past decade (Peace Corps 2007).

Spanish is recognized as the official language as it is used in government, culture and commerce. However, Quechua is also recognized as an official language but through time has been replaced by Spanish. Presently Quechua is spoken in the Andean highlands along with other derived languages. Some communities near the Amazon basin and on the eastern side of the Andes have also adopted other languages (Peace Corps 2007).

\subsection{Environment}

Perú is an environmentally diverse country with various climates ranging from arid deserts along the pacific coast to the Andean mountains and the Amazonian rainforest. As a result, the country is host to a wide plethora of flora and fauna diversity (Peace Corps 2007).

Due to its geographical diversity its climates vary widely throughout different regions. The valleys experience moderate climates, while the highlands are cool and dry with some areas experiencing intense rainy seasons. The Amazon rainforests are hot and humid. The country has experienced extended period of droughts and floods as global climate change occurs. It is also prone to earthquakes, mostly in the northern coast (Peace Corps 2007). 


\section{Description of Study Area}

\subsection{Geography}

The district of Lámud, capital of the Province of Luya, is located in the region of Amazonas in the northern part of the country. Ranging from altitudes between 1,950 meters and 2,300 meters the site is surrounded by mountain ranges. With an area of $69.49 \mathrm{~km}^{2}$, Lámud makes up $2.15 \%$ of the province. The province is divided between 23 districts, 459 populated communities both urban and rural. It is bordered by the Jucusbamba River which runs north to south setting a boundary with the Province of Chachapoyas, as shown in Figure 9.1 below.

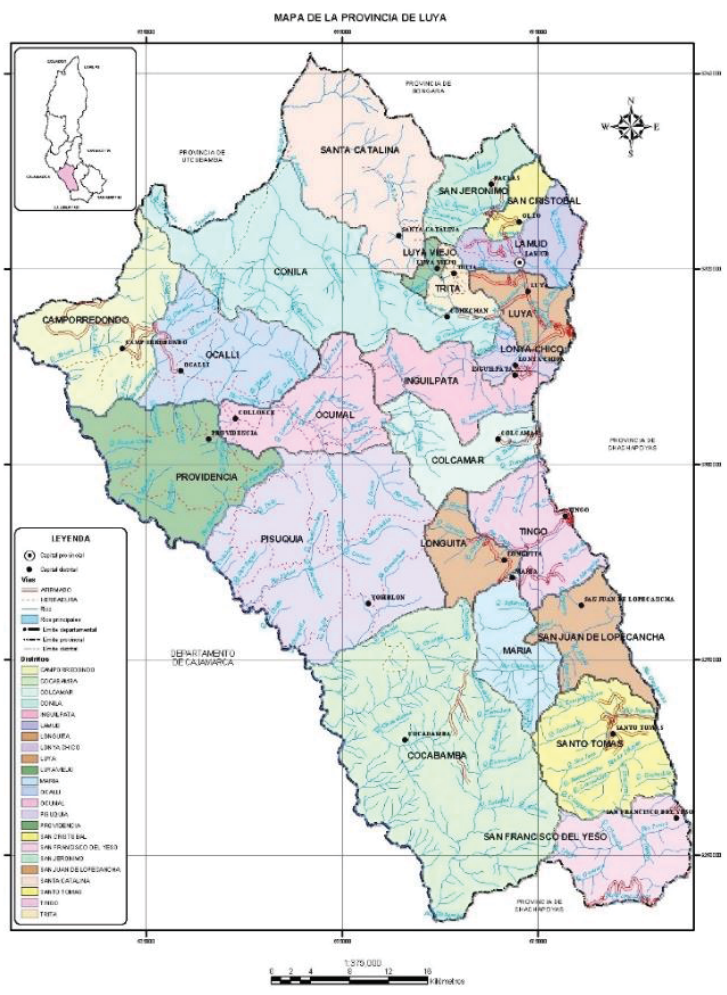

Figure 9.1 Map of Province of Luya with boundaries and location of districts

Source: Regional Government of Amazonas digital archives (Regional Government of Amazonas 2012). 


\subsection{Climate}

The Province of Luya, as in the rest of the Region, experiences two well defined seasons which are the dry season, between the months of June to November and the rainy season, which takes place between December to May. Annual rainfall volumes range from 1,200 to 1,800 $\mathrm{mm}$ (Huarino Ch. 2009).

Temperatures also vary throughout the region, thus creating a rich variety of microclimates and wildlife, with lows in the $7^{\circ} \mathrm{C}$ and the highs at $24^{\circ} \mathrm{C}$ on average.

\subsection{Hydrology}

The province has three main watersheds defined by the Marañon River running from south to northeast and whose main tributaries are the Vilaya, Delo, Huangosá, Galeras and J umite Rivers originating from the Vilaya, Shucauala and Condorpuna mountain ranges. The Utcubamba watershed is defined by the Urcubamba River and runs from south to the northeast defining the boundary between the provinces of Chachapoyas and Bongará. (Bustamante Oblitas 2012).

\subsection{Demographics}

With a population of about 2800 people in Lámud the majority of the population is between the ages of 15-64 years old with females making up about $40 \%$ of the population. With the majority of the population being farmers and a small portion with higher education degrees in education, agricultural techniques and nursing. Most of the individuals who are coming into Lámud for work related purposes hold higher education degree in politics, engineering and accounting. However, they are relatively transient and only stay in the city during the weekdays, traveling back to Chachapoyas, 
the Regional Capital on the weekends. They are also a transient part of the population as their contracts or post are dependent on political parties or other seasonal projects.

\subsection{Economic Activities}

In the city of Lámud, subsistence agriculture is the most prominent practice, with potatoes being the main crop as see in Figure 9.2. However, throughout the province of Luya potato, coffee and cocoa are all crops aimed at commercialization becoming the main source of income for farmers. With coffee being the largest crop taking over 13,358 hectares and a production of 13,117 tons. Followed by potato with an area of 2.223 hectares and a production of 31,446 tons. Amilaceo maize extending an area of 2,208 hectares and a production of 1.923 tons; Yellow maize covering an area of 1,065 hectares and a production of 2,484 tons; Cacao covering an area of 284 hectares and a production of 235 tons (Bustamante Oblitas 2012). 


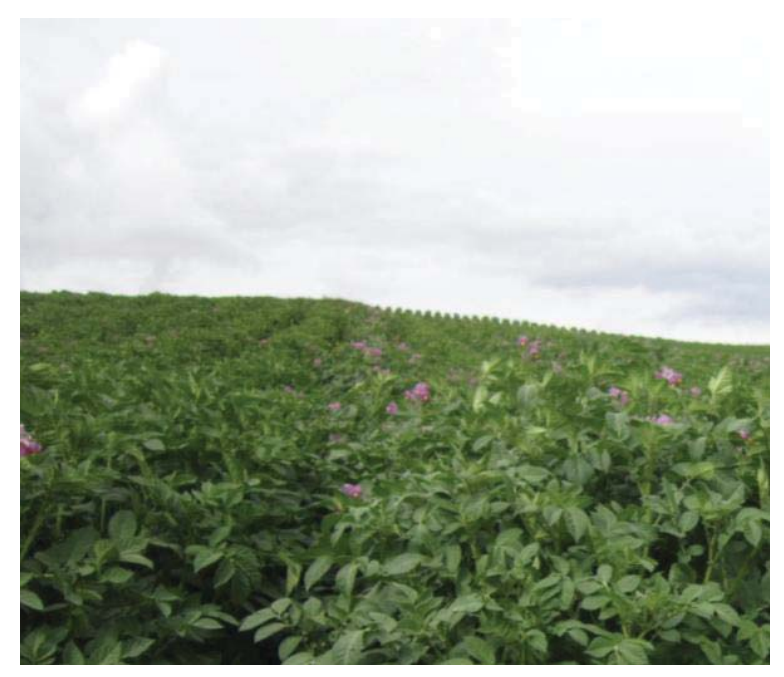

Figure 9.2 Flowering Potato Crop

Note: Most common crop within Lámud.

The raising of livestock is the second largest economic activity. There are approximately 45,370 ha of land suitable for the implementation of cultivated grasses to support this activity.

The development of extensive livestock, includes sheep, which highly influences the production of milk and meat resulting beneficial to the communities. The raising of a variety of livestock such as cattle, pigs, sheep and small animals is of preference. The husbandry of small animals, such as guinea pigs and chickens, is carried out as a subsistence practice.

The implementation of forestry production is mostly for personal and local use with the majority of it being used for the construction of dwellings and cooking. According to the watershed's hydrography, the following tree species are being extracted from the Marañon Watershed: Acerillo, Guayo, Siogue, Morocho, etc. Within the Utcubamba 
watershed it is species such as Height Cedar, Alder, Siogue, Lanche, Eucalyptus, etc. which are being used (Bustamante Oblitas 2012).

The province of Luya counts with various natural and cultural touristic sites. The most distinct amongst them is Kuelap, which is the region's icon. Amongst other well-known sites are the Cavern of Quiocta, the Sacorfigi of Karajía, Town of the Dead, the archeological complex of Gran Vilaya, and the Valley of Huaylla Belén all of which can be accessed by car from Lámud. Due to the growth of tourism, the city has experienced economic growth through the establishment of hotels, restaurants and a tourism cooperative all aimed at catering to tourists.

\subsection{Water and Sewage}

\section{Potable Water}

The Empresa Publica de Servicios (EPS) Jucusbamba is the sole service provider of potable water and sewage to the city of Lámud. For a monthly fee of s/.6.00 Soles local currency - the equivalent of $\$ 2.00$ US Dollars, single family homes are able to obtain a connection to the system. This fee is meant to cover all maintenance and operational costs. The level of delinquency of past due accounts is currently at a $10 \%$ (Municipalidad Provincial de Luya 2011).

The main water sources are from La Manzana intake which presents a flow rate of $2.50 \mathrm{lps}$ during the dry season and peaking at $6 \mathrm{lps}$ during the rainy seasons. The secondary source if from a nearby spring located along the road Luya-Lámud. This source is pumped through a 4" PVC system into the reservoir at a rate of 1.10 Ips (Municipalidad Provincial de Luya 2011). 


\section{Treatment Plant}

The existing treatment plant, built in 1962, has 1 flocculator, 1 sedimentation unit, and a series of rapid sand filters (Municipalidad Provincial de Luya 2011).

\section{Reservoirs}

Three reservoirs are currently used in order to provide uninterrupted service. A $10 \mathrm{~m}^{3}$ concrete reservoir built in 1990 is located above city elevation. The water is goes through a sedimentation process before being stored in the reservoir. As it leaves the reservoir it is chlorinated and then distributed. The second reservoir, built in 1978 , is located $100 \mathrm{~m}$ from the treatment plant. With a capacity of $80 \mathrm{~m}^{3}$ this reservoir is fed through 8" lines. The third reservoir, is a cylindrical concrete structure built in 2011, it is located southeast of the city and fed by a pump (Municipalidad Provincial de Luya 2011).

\section{Sewage}

$79.8 \%$ of the population in Lámud is connected to the sewage system. The current administration has made it a priority to provide appropriate sewage connections to $100 \%$ of its citizens before the end of their term in 2019 (Municipalidad Provincial de Luya 2011).

The system is lacking an appropriate connection to the sewage treatment plant, and despite the health and environmental laws established by the regional government, the raw sewage discharges immediately into the Jucusbamba River which borders the city. This results in a public health risk for both the city of Lámud and the communities downstream of the river which use the river for household, personal and irrigation purposes. 


\section{Stormwater Management}

Prior to 2013 the city of Lamud did not have any type of storm water management plan nor infrastructure in place. Roads were unpaved and some had been compacted as seen in Figure 9.3. At this point, as part of a project to renovate the water and sewage system, about 1300 linear meters of the main artery of the city were paved and conventional stormwater management techniques incorporated as seen in Figure 9.4. There is an elevation change of $800+$ meters allowing runoff to reach high velocity rates. Due to the steepness of the site, there is minimal retention and infiltration of stormwater and a high rate of solids and contaminants are being carried by runoff into the river. There are no detention basins, thus preventing post-development peak discharge rates to be controlled. Grate inlets intercept sheet flow runoff into concrete street gutters which channel the water off the street and discharge out to receiving rivers. However, due to design flaws, gutters flood during heavy storms and inlets and outlets become cluttered with debris. There is no strategic maintenance plan in place, therefore maintenance occurs during the rainy season as needed, usually after the occurrence of flooding. There are no individual connections to the stormwater system, resulting in grey waters from households activities e.g. washing, cleaning and bathing to discharge onto the roads or backyards. 


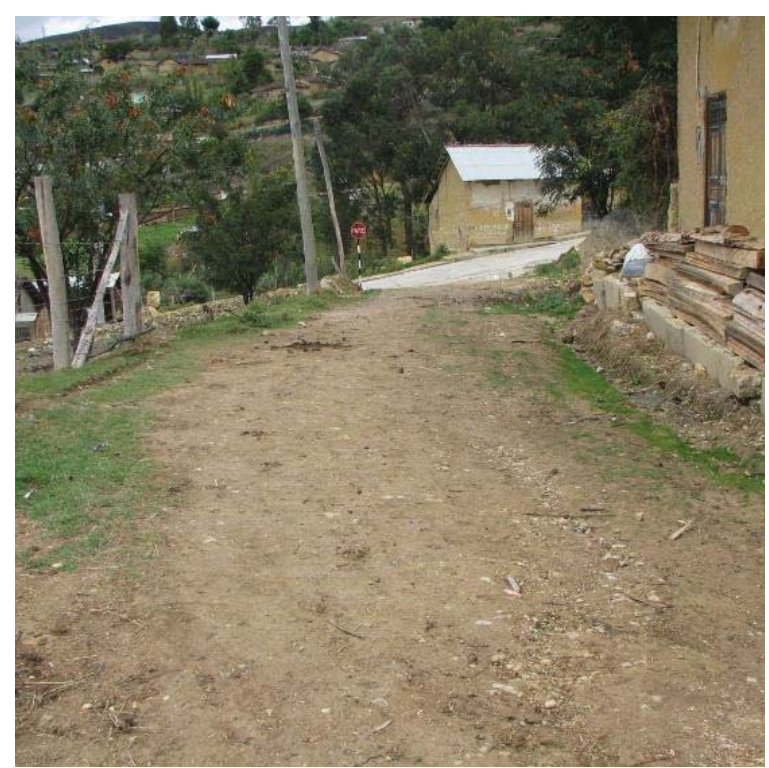

Figure 9.3 Unpaved Road Conditions in Lámud Photo by Author

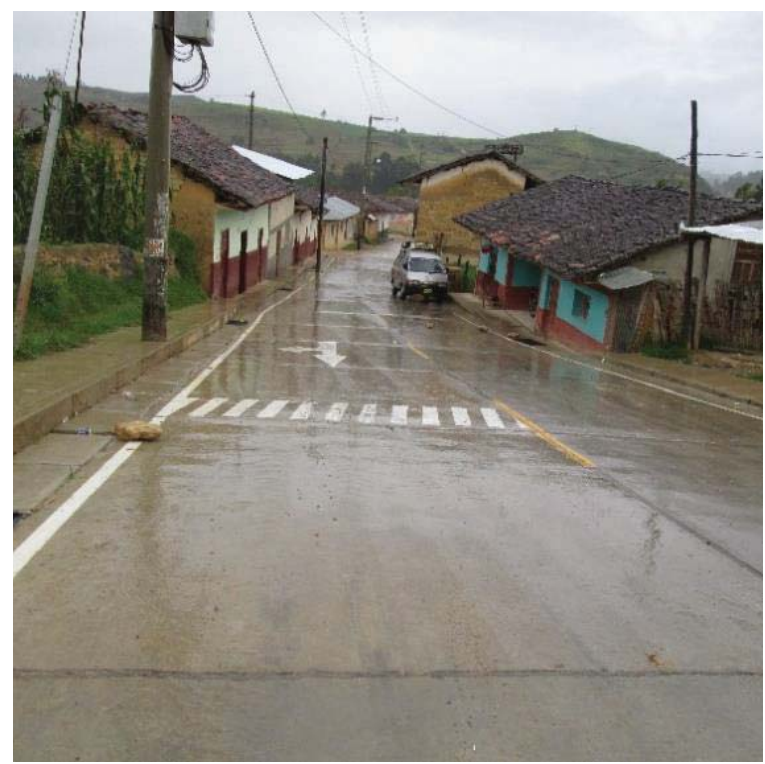

Figure 9.4 Paved Road in Lámud with Stormwater Management System Photo by Author 


\section{Hygiene and the stormwater system}

Prior to paving the main artery of the city, stormwater flowed through channels formed naturally from runoff patterns. These natural channels caused ponding and flooding resulting in structural damage to buildings - residences, commercial, institutional and infrastructure. Additionally, only $79.8 \%$ of the population is connected to appropriate underground sanitation systems. In the cases where families use a latrine or practice open defecation, sewage becomes mixed with runoff or flooding which results in public health hazards. 


\section{Hydrologic and hydraulic design methods}

The design of stormwater systems is relatively simple - using gravity, pipes and minimal maintenance. The systems in Lámud were designed using the Rational Method - a synthetic model method - and a synthetic hydrograph, for which observed data is not required. Given that the system is efficient enough, there is not a large effort placed on collecting site specific data. Systems are designed based on peak flows, however there are other variables such as varying flow conditions that are not considered. The lack of accurate data is prominent reason for infrastructure failure. Once the system was in place it was then adopted by the municipality as a model for other locations. The adoption of these technologies through ordinances and design manuals is of high value for large scale implementation. However, when the design methods are not verified and designed to be site specific they may present themselves as obstacles to development and stormwater management.

\subsection{Urban Stormwater Management in Developing Countries}

As watersheds become developed through urbanization or land use changes, their hydrology changes resulting in increased peak discharge rates. Through urbanization, stormwater management systems aim to reduce or prevent flooding caused by precipitation. Conventional techniques such as street gutters, storm sewers and detention basins may all be components of a traditional stormwater management system. Due to the imperviousness of these systems, runoff is carried off sites at faster rates and contribute to higher and faster peak discharges (Wurbs and James 2001). Though these techniques are effective in that they minimize and in some cases do not

allow flooding to occur, they are ineffective in maintaining the watershed's natural hydrology. This alteration may result in changes of local ecosystems which in turn may 
have a direct impact to the local economies of rural communities who depend on agriculture as their main source of income. Additionally, the rapid re-direction of rainfall from sites does not allow for slow infiltration of rainfall and thus missing the opportunity to recharge groundwater aquifers as well as becoming a contaminant source for receiving waters.

Though the implementation of conventional stormwater management systems have allowed cities the opportunity to advance socially and economically they have also been a reason for the alteration of natural systems. Rural communities are particularly vulnerable to urbanization because it usually occurs in unplanned and unorganized patterns under risky poverty conditions. In addition, local governments lack both the human and financial resources to design and implement appropriate urban planning projects. However, rural communities pose a high level of solidarity and community involvement (Wondimu and Alfakhi 2001). In Lámud for instance, the community is responsible for the operation and maintenance of public common spaces such as the cemetery, recreational green spaces and religious spaces. Under these circumstance the community coordinates workdays known as faenas as seen in Figure 9.5 where routine cleaning and maintenance is carried out. This practice can be an asset when analyzing the adoption and maintenance of LID BMPs. 


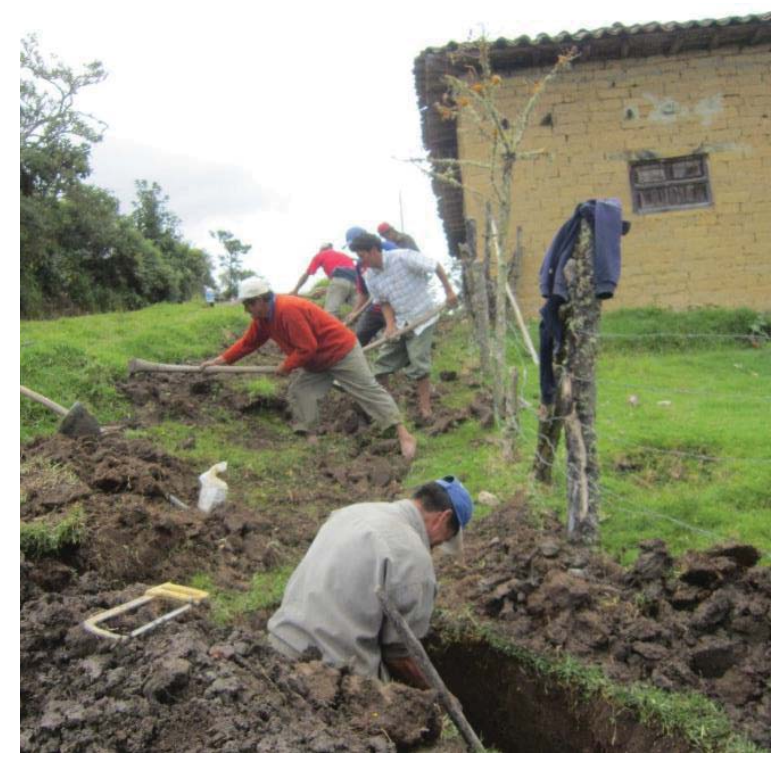

Figure 9.5 Community members during a Faena

Note: Men digging trenches for the improvement of water distributions lines.

Stormwater can pose severe problems in developing countries due to weak structural and financial systems. Flooding in these communities usually has catastrophic results by destroying shelters, crops, infrastructure and claiming lives. When stormwater management systems are in place, they are often inefficient due to rapid population growth and inappropriate use as is their mixed use with sewage (Goldenfum, et al. 2007).

Stormwater management solutions implemented in developing countries have been adopted from developed countries without adaptations to accommodate for cultural or economic differences in developing and rural settings. As a result, in some cases, new technologies result in a waste of time and money due to their lack of adaptability. The lack of studies based on appropriate technologies for rural communities and the lack of opportunity given to stakeholders to participate in the planning process have been attributed as reason for system failure (Wondimu and Alfakhi 2001). As presented in a study carried out in Proto Alegre, Brazil, implementation and adoption of new 
technologies in developing countries encounter challenges at various levels educational, technical and institutional (Goldenfum, et al. 2007). The success of urbanization in these communities will be dependent on their flexibility to adapt to local social, geographic and economic conditions. As well as having access to hydraulic and hydrologic data. Technical education and training is key for operators, landowners and local authorities to support the implementation of new and innovative systems. (Goldenfum, et al. 2007).

\subsection{Low Impact Development}

Low I mpact Development (LID) aims to maintain and restore the natural hydrology of watersheds prior to development through Best Management Practices (BMPs) techniques of infiltration and ponding. Similar techniques known as Sustainable Urban Drainage System (SUDS) can be seen in Europe. In Europe these techniques are used to maintain good public health, protect water sources and preserve biodiversity (Zhou 2014). In Australia they have implemented what is referred to as Water Sensitive Urban Design (WSUD) which is an all-encompassing plan to incorporate urban drainage system into urban planning and thus making these an integral part of cities in which they harmonize with the urban landscape while minimizing negative environmental impact (Roy, et al. 2008).

There are numerous research projects and actions underway to better understand how LID BMPs can be effectively incorporated into urban design. Denmark's “Water in Urban Areas" projects seeks to turn conventional urban water systems into "climatically robust systems" (Vand I Byer 2015). As well at their 2BG "Black, Blue and Green" project which looks to promote all-inclusive sustainable urban water systems (Fryd, et al. 2009). The Construction Industry Research and Information Association 
(CIRIA) in the UK is committed to providing educational material through the publishing of documents based on effective design practices and projects (Ashley, et al. 2007). Ireland's capital, Dublin, involved different stakeholders to develop an assessment of the drainage of constructed wetlands (Hennelly 2005). Input from various stakeholders provide a deeper understanding of a wide range of impacts and benefits. In Sweden the Swedish Foundation for Strategic Research Programme initiated a 6-year plan to protect water sources in urban areas (Hellström, J eppsson and Kärrman 2000). One of the largest initiatives in this topic has been led in Australia by the Cooperative Research Center (CRC) for Water Sensitive Cities which brings together multidisciplinary teams to develop sustainable strategies for the development and transformation of cities (Wong and Brown 2009).

Despite the amount of research that has been carried out focusing on LID and other urban green initiatives, very little has been carried out in the context of rural settings. However, there is a considerable amount of research available focusing on water and sanitation in developing countries and rural communities. The research looks into infrastructure, access to water sources and a compound of key elements for necessary for sustainability - social, economic and environmental. Due to the similarity between water and sanitation systems and stormwater management systems, much of this research can be applied and used to support further studies on stormwater management in rural settings. For instance, research carried out in Nigeria suggested the implementation of Water Access Awareness Program (WAAP) to minimize public health issues caused by the contamination of water sources. The study also points out various human activities: agricultural, garbage disposal, human waste disposal, as prime contributors of contaminants (Nnadi 2008). The impact of all of these could be lessened by the implementation of LID BMPs and thus further research would be valuable. Other research has expressed the importance of taking into consideration 20 
key aspects - social, economic and environmental - as means of efficiency and sustainability in the implementation of stormwater management in developing countries (Wilderer 2004). The study carried out in Porto, Brazil showed that the adoption of new technologies presented challenges in the implementation of LID BMPs. As it explains the challenges encountered today after the adoption of detention basins in the 90 s and how currently there still exist opposition in the implementation of any other BMPs (Goldenfum, et al. 2007). This is attributed to the lack of technical information provided to landowners, community leaders and other participants on the understanding of benefits of said systems, as well as cultural barriers which keeping communities from adopting new technologies. 


\section{Data Collection}

This study aims at identifying the most appropriate LID BMPs combination based on cost, runoff and probability of maintenance in the city of Lámud. Based on geography, availability of materials, low operation and maintenance and land use, the LID BMPS chosen for this study were infiltration trenches, vegetative swales and retention ponds.

In order to achieve this, environmental, economic and social data were collected using various methods described in detail in the following sections below.

\subsection{Environmental}

Data was collected based on the inputs required by the Stormwater Management Model (SWMM). Site plans in digital and printed form were obtained from the Ministry of Housing, Construction and Sanitation - Provincial Municipality of Luya (Ministerio de Vivienda, Construcción y Saneamiento - Municipalidad de la Provincial de Luya 2011). These documents provided information on location and size of lots, roads and streams, elevation and contour lines of site, land typology and use. The accuracy of the site plan was verified by performing on-site measurements and comparing them to the site plan. This site plan was used as a background image to dictate the shape, size and location of lots, referred to as subcatchments, in the study area. Rainfall data was obtained from the Natural Meteorological Service of Perú (SENAMHI - Servicio Nacional de Meteorologia Hidrolica del Perú) and can be referenced in Appendix A: Chachapoyas Rainfall Data. The rainfall data was for a 12 month period from September 2013 to August 2014 with a rainy season between December to May and a total rainfall volume of $925 \mathrm{~mm}$. In comparison to annual rainfall volumes from other years, which range from 1,200 to $1,800 \mathrm{~mm}$, this was not a particularly rainy year (Huarino Ch. 2009). 
For the purpose of this study, the study site selected only represent a small percentage of a larger watershed and thus the data collected is unique to the particular study site. A site plan is shown in Figure 10.1 with the study area denoted by the shaded region.

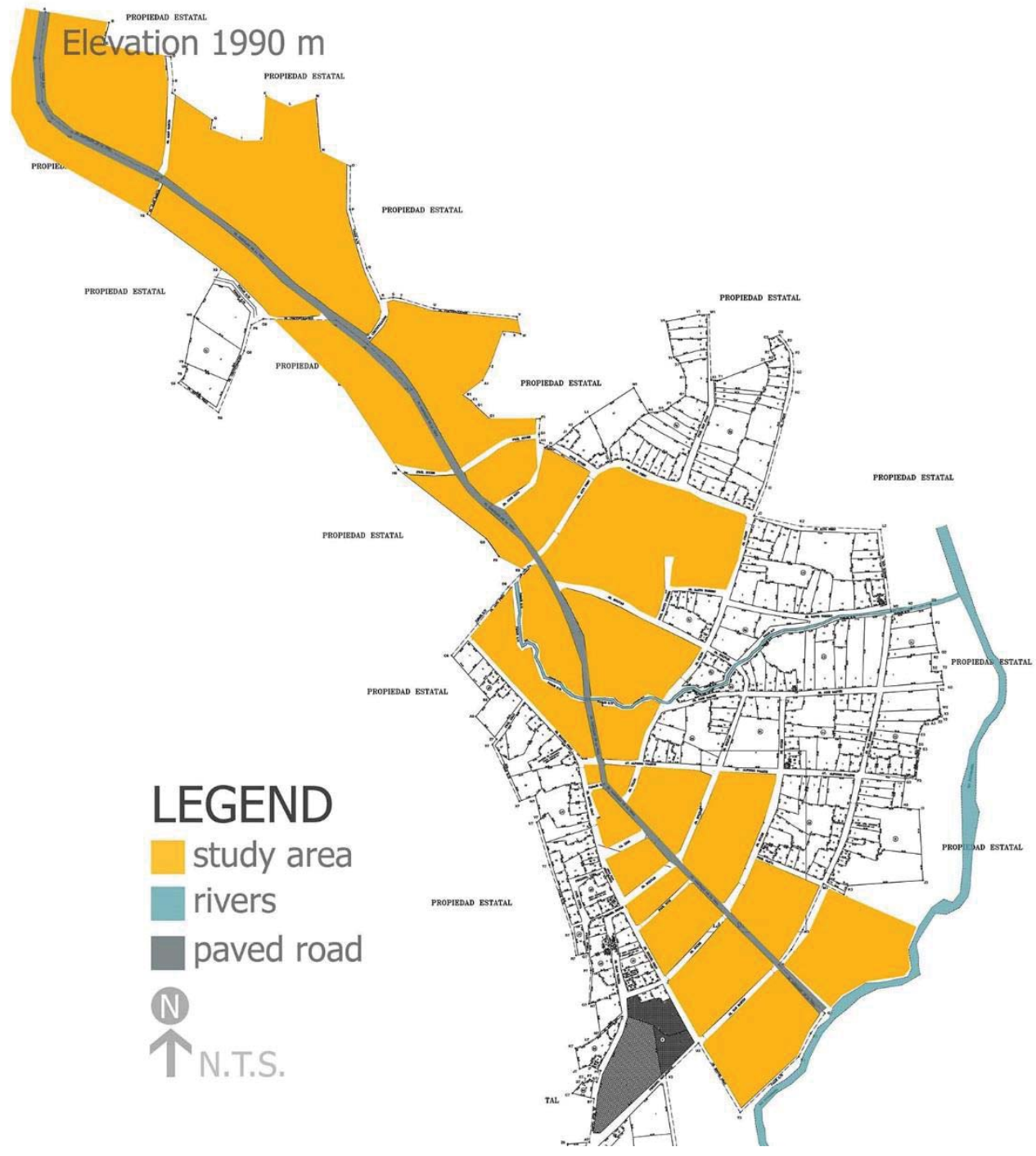

Figure 10.1 Site Plan of Lámud

Note: Site Plan with study are denoted in shaded area. 


\subsection{Economic}

Water Environment Research Foundation (WERF) Models, which will be discussed in further detail in section 11.3. have been used as a guide of the categories and types of materials and labor needed for each LID BMP and thus dictated the data required to be collected. Values used for cost calculations were collected on site in the year 2014 . Cost for materials were obtained from local hardware stores. Wages for labor of skilled workers was obtained through word of mouth and by referencing construction budgets of municipal projects. Values for both materials and labor can be reference in Table 10.1 below. Maintenance is not included in this table as it depends on the level of maintenance - low, medium, high - opted for each LID BMP and calculated on an hourly basis. It is assumed that costs for design, construction and maintenance for LID BMPs is to be covered by local government with the participation of landowners during the maintenance phase through un-skilled labor activities such as digging, moving of materials in-site and planting or placement of materials. Cost calculations are discussed in detailed in section 11.3.2. 
Table 10.1 Local Values for Materials and Labor

\begin{tabular}{|c|c|c|c|}
\hline Conversion Rate & 2.8 & & \\
\hline \multirow{2}{*}{ DESCRIPTION } & \multirow{2}{*}{ UNIT } & \multicolumn{2}{|c|}{ COST } \\
\hline & & SOLES (S/.) & DOLLARS (\$) \\
\hline Impermeable Liner & $\mathrm{m}^{2}$ & 1.00 & $\$ 0.36$ \\
\hline Soil Amendment & $\mathrm{m}^{3}$ & 7.15 & $\$ 2.55$ \\
\hline Overflow Structure (rock riprap) & $\mathrm{m}^{3}$ & 8.07 & $\$ 2.88$ \\
\hline \multicolumn{4}{|l|}{ Curbing around facility } \\
\hline Cement & bag & 25.00 & $\$ 8.93$ \\
\hline Rebar (9 meters) & bar & 25.00 & $\$ 8.93$ \\
\hline Bark Mulch & $\mathrm{m}^{3}$ & 0.10 & $\$ 0.04$ \\
\hline Topsoil & $\mathrm{m}^{3}$ & $\mathrm{CC}^{*}$ & \\
\hline Vegetation & $\mathrm{m}^{3}$ & $\mathrm{CC}^{*}$ & \\
\hline Labor & $\mathrm{hr}$ & 1.00 & $\$ 0.36$ \\
\hline Engineering (\%25 of capital cost) & flat fee & & \\
\hline *Community Contribution & & & \\
\hline
\end{tabular}

\subsection{Social}

Information on land use was collected through site observation over the course of the author's Peace Corps service while living in the study site and are based on the author's perception and experience in working with community members. Land use was determined on the types of activities taking place in each subcatchment categorized as agricultural, low density residential, medium level residential or institutional depending on the percentage of impervious area on each subcatchment. 


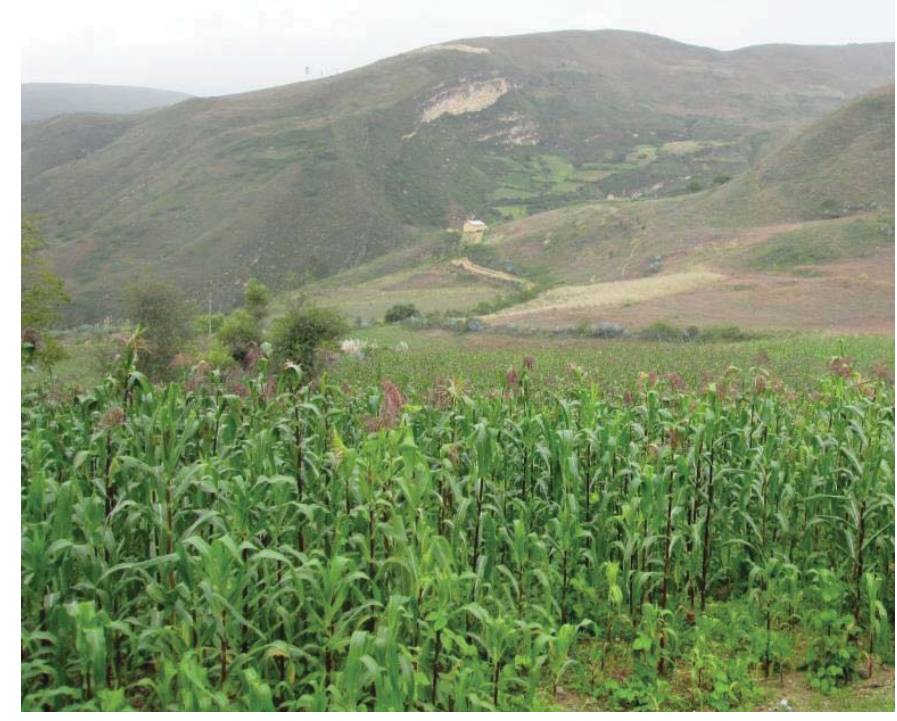

Figure 10.2 Agricultural Land Use

Note: Subcatchment of Agricultural Land Use. MPF value of 1 .

Agricultural, shown above in Figure 10.2, is being defined as a subcatchment used to grow crops and serve agricultural purposes and less than $10 \%$ of impermeable surfaces. 


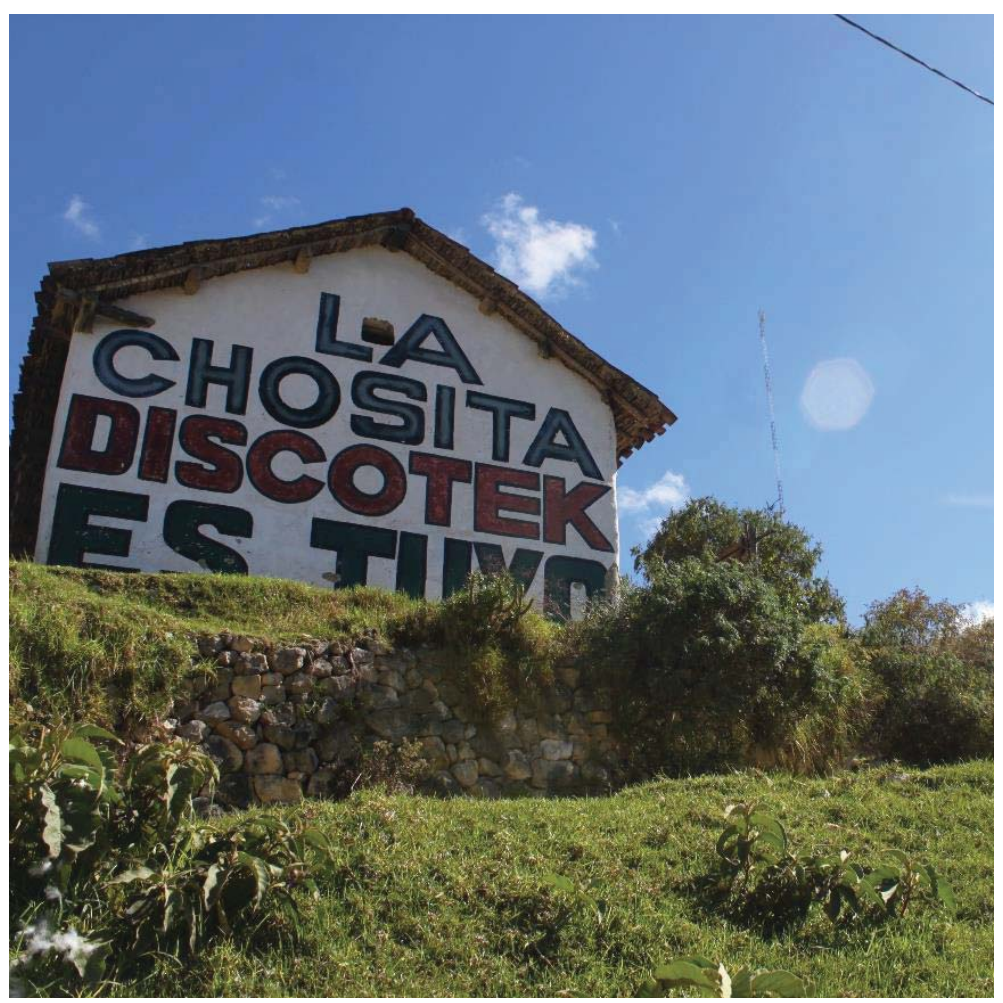

Figure 10.3 Low Residential Land Use

Note: Subcatchment of Low Residential Land Use. MPF value of 2.

Low residential, shown in Figure 10.3 above, is defined as subcatchments where there is construction - either temporary or permanent - and whose impermeable surfaces range between $25 \%$ to $50 \%$. Medium residential, shown in Figure 10.4 below, is defined as subcatchments where there is permanent construction and whose impermeable surface area ranges between $50 \%$ to $70 \%$. Institutional, shown in Figure 10.5 below, defined as subcatchments occupied by large constructions and whose impermeable surface takes up more than $90 \%$ of the subcatchment's area. 


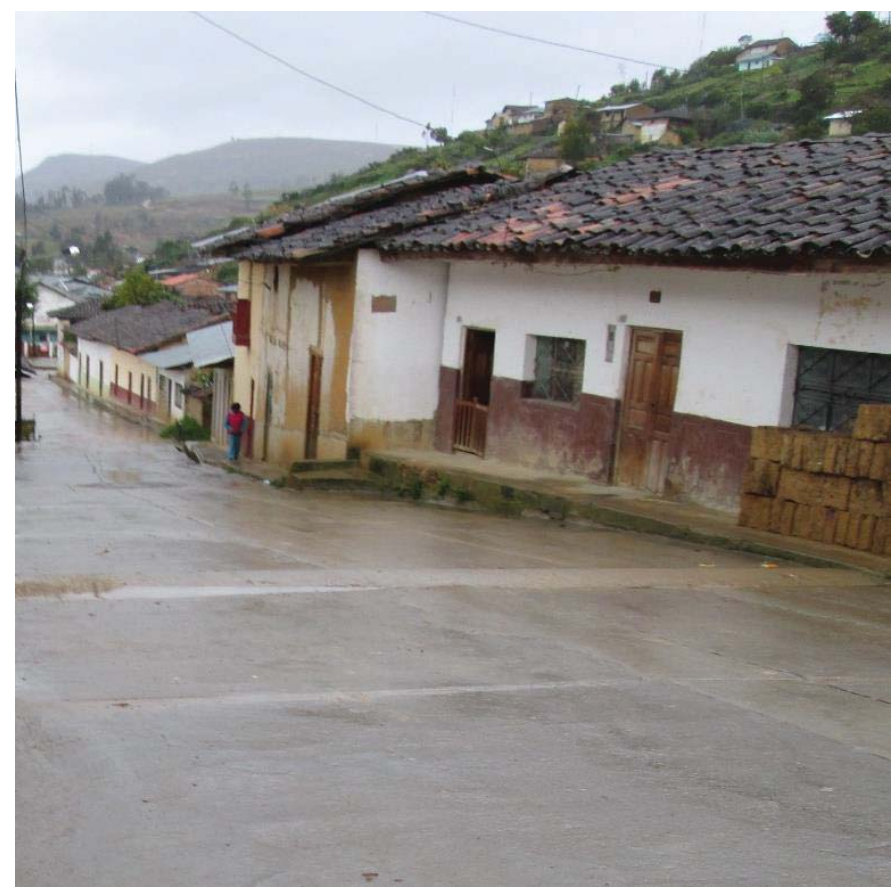

Figure 10.4 Medium Residential Land Use

Note: Subcatchment of Medium Residential Land Use. MPF value of 3.

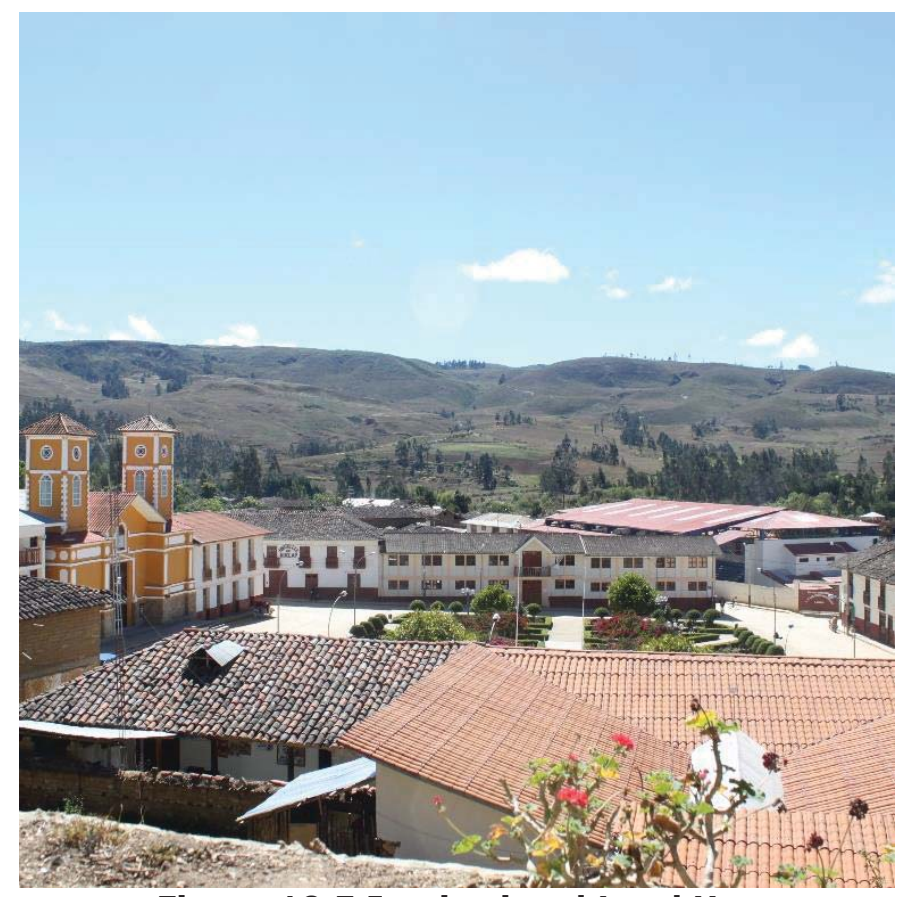

Figure 10.5 Institutional Land Use

Note: Subcatchment of Institutional Land Use. MPF value of 4.

Table 10.2 below shows how each subcatchment has been categorized. Based on land use an assumption is made that agricultural subcatchments will be more likely to be 
maintained since landowners of these plots work on their lands on a regular basis and thus would be more like to carry out the manual labor involved in the maintenance of these systems. It is also important to note, that owners of agricultural subcatchments would benefit directly from the use of LID BMPs, given that these systems would protect their crops from flooding and thus protect their investment. Based on that observation, it is assumed that agricultural workers would be more likely to maintain the systems because they would obtain a direct benefit from them. Whereas subcatchments categorized as institutional would be less likely to maintain LID BMP systems given that the occupants of institutions such as the municipality, church and schoolboard, do not carry out activities dealing with the land or soils of the subcatchment, but rather hold posts in offices or activities not requiring manual labor and thus less likely to perform the manual labor required to maintain LID BMPs. Additionally, the users of the institutional subcatchments would not find a direct benefit from the implementation of these systems. 
Table 10.2 Land Use Categories

\begin{tabular}{|c|c|c|}
\hline SUBCATCHMENT & $\%$ DEVELOPED & CATEGORY \\
\hline $\mathrm{S} 1$ & $10 \%$ & agricultural \\
\hline S2 & $10 \%$ & agricultural \\
\hline S3 & $25 \%$ & I-resid \\
\hline S4 & $25 \%$ & I-resid \\
\hline S5 & $25 \%$ & I-resid \\
\hline S6 & $25 \%$ & I-resid \\
\hline S7 & $30 \%$ & I-resid \\
\hline S8 & $30 \%$ & I-resid \\
\hline S9 & $30 \%$ & I-resid \\
\hline S10 & $30 \%$ & I-resid \\
\hline S11a & $35 \%$ & I-resid \\
\hline S11b & $35 \%$ & I-resid \\
\hline S12a & $35 \%$ & I-resid \\
\hline $\mathrm{S} 12 \mathrm{~b}$ & $40 \%$ & m-resid \\
\hline S13 & $40 \%$ & m-resid \\
\hline S14 & $95 \%$ & Institutional \\
\hline S15 & $90 \%$ & Institutional \\
\hline S16 & $70 \%$ & Institutional \\
\hline S17 & $90 \%$ & Institutional \\
\hline S18 & $70 \%$ & m-resid \\
\hline S19 & $70 \%$ & m-resid \\
\hline S20 & $70 \%$ & m-resid \\
\hline $\mathrm{S} 21$ & $70 \%$ & m-resid \\
\hline S22 & $70 \%$ & m-resid \\
\hline $\mathrm{S} 23$ & $10 \%$ & agricultural \\
\hline S24 & $70 \%$ & m-resid \\
\hline
\end{tabular}

Note: Percent developed refers to percent of impermeable surface area in subcatchment 


\section{Methods}

\subsection{Introduction}

In order to analyze the data collected, the following methods were implemented: A hydraulic model, SWMM 5.1, was used to analyze environmental data. The Water Environment Research Foundation (WERF) cost model were used as a guide to analyze cost and a Maintenance Probability Factor was developed to analyze the probability of maintenance. Below, is a general outline of the methodology applied in order to carry out the study:

1. Collection of data based on required inputs of models as follows.

a. SWMM 5.1: rainfall, soil types, site slopes and location of subcatchments.

b. WERF Life Cost Models: market value of materials and labor costs

c. Maintenance Probability: Land use and activity of each subcatchment

2. Analysis of data

a. Environmental: Using SWMM, 10 cases were set with a variations of LID BMP combinations. Results were analyzed for totals of runoff per case and compared to pre-developmental natural runoff levels.

b. Economic: WERF Life Cost Models were used as a guideline to calculate cost for design, construction and maintenance of LID BMPs over a 10 year span.

c. Social: Land use of each subcatchment was given a value ranging from 1 to 4 . A Maintenance probability Factor was developed by obtaining an average value of the subcatchments in each case. Cases were ranked based on MPF values. 
3. Results

a. SWMM 5.1: Cases were ranked based on proximity of runoff level to natural case.

b. Cost Models: Total costs for each case were calculated.

c. Maintenance Probability: Cases were ranked based on probability of Maintenance

4. Analysis

a. Cost Benefit Ratio (CBR): CBR was developed to quantify the ratio of cost to benefit. Cases were ranked based on CBR value.

b. Cases were plotted based on MPF and CBR variables to better understand this relationship.

c. Trends were identified and analyzed.

Each method is discussed in further detail in the sections below.

\subsection{SWMM 5.1 EPA Hydraulic Model}

\subsubsection{Introduction}

The EPA has developed SWMM as a tool for modeling rainfall-runoff quantity and quality. The model allows for the modeling of hydrologic behaviors of stormwater runoff in urban areas throughout single or continuous rainfall events. Runoff is simulated through the designation of subcatchments - areas collecting precipitation and producing runoff. The model provides various options to simulate routing through systems of pipes, channels, storage/ treatment, devices, pumps and regulators. Once these variables are put into place cases can be carried out where SWMM can provide results on parameters such as quantity and quality of runoff, flow rates, flow depths in pipes and water quality (Rossman 2010). 
SWMM 5.1, the latest version of the software, can now model hydrologic behavior of the following LID systems: permeable pavements, rain gardens, green roofs, street planters, rain barrels, infiltration trenches and vegetative swales. These options allow the modeling of various stormwater management techniques and in order to identify the most efficient techniques (EPA 2015).

The model is an inclusive tool with capabilities to simulate time-varying rainfall, evaporations of standing water, snow accumulation and melting, rainfall interception from depression storage, infiltration of rainfall into unsaturated soils, percolation of infiltrated water into groundwater layers, interflow between groundwater and the drainage system, nonlinear reservoir routing of overland flow and runoff reduction through LID controls.

Its application varies from research to practice as it has been implemented in studies both in the United States and internationally. It is commonly used to design and size flood control elements and systems as well as a tool to evaluate Hydrolic behaviors such as infiltration and contamination loads (Rossman 2010).

SWMM 5.1 software is available to the public at no cost and may be downloaded from the EPA website (EPA 2015).

\subsubsection{Methodology}

SWMM requires user provided inputs to set up subcatchments, nodes, junctions and LID BMPs - each referred to as an object. While some values are set as common values, also known as defaults, others are specific to the specifications of each object. For instance subcatchment properties will vary in percentage of permeability, slope and area, but runoff will be calculated using the same infiltration method for all subcatchments. The layout of all objects in SWMM can be viewed below in Figure 11.1 
and site plans denoting the type of LID BMP implemented per subcatchment for each case can be referenced in Appendix B: LID BMPs Identification Diagram per case. 


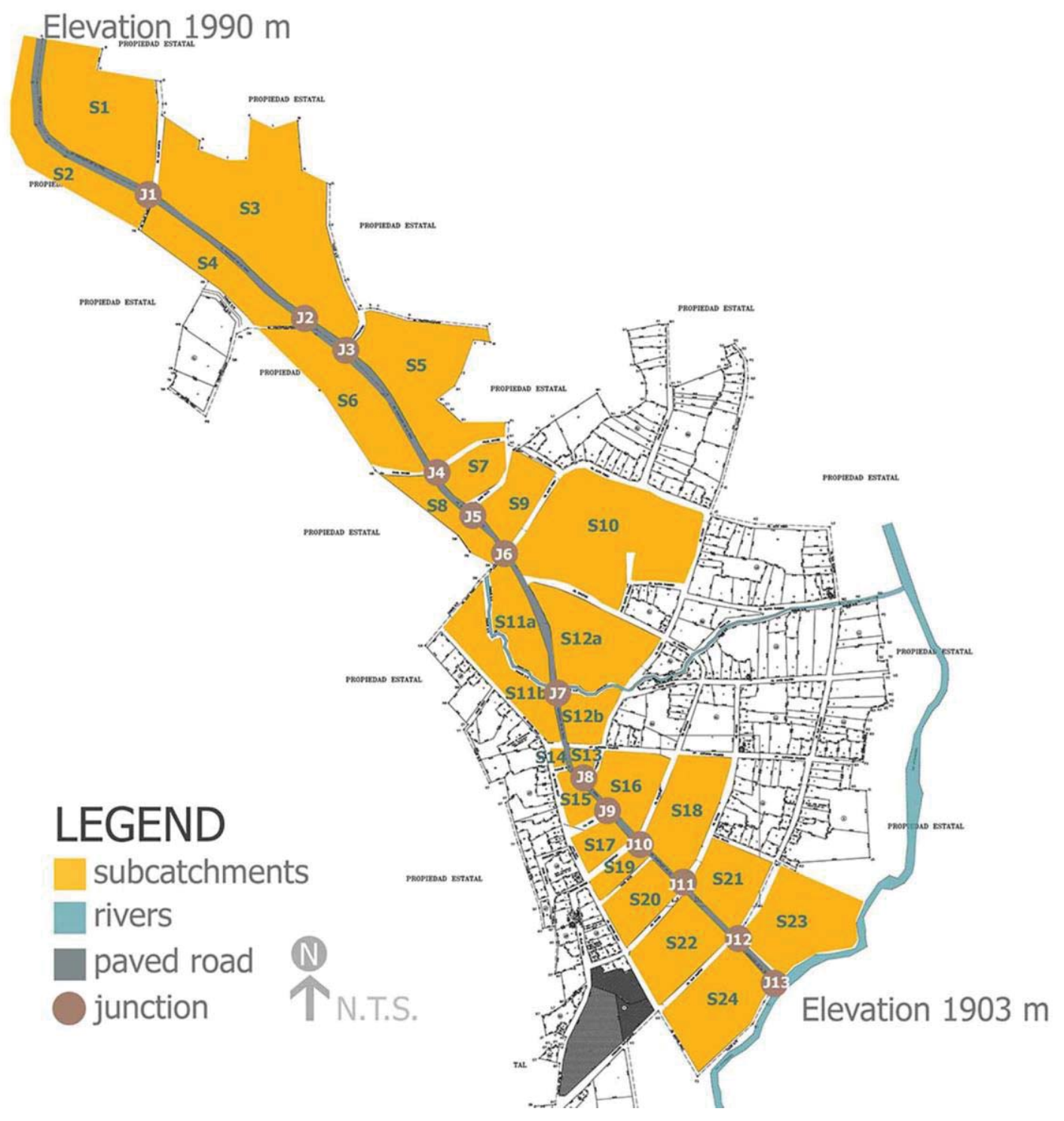

Figure 11.1 SWMM Diagram Layout of Objects

Source: Diagram produced by author. 
Placement of LID BMPs was determined by site conditions, availability of area and steepness of each subcatchment. For retention ponds, subcatchments with little to no construction were ideal due to the area required for their implementation. For vegetated swales, subcatchments with slopes greater than $10 \%$ were not considered, as this characteristic would present a risk for system failure. As for infiltration trenches, they tend to take up about $10 \%$ of the total subcatchment area and in practice are usually installed along the boundaries of the subcatchment making them a flexible solution under various circumstances and thus used throughout all subcatchment. Table 11.1 lists the site characteristics of each subcatchment including slope, area and the area of the LID BMPs used throughout the 10 cases. Shaded cells are for LID BMP which were omitted based on subcatchments site characteristics.

Design equations for each LID BMP - infiltration trenches, vegetated swales and retention ponds - were used to determine sizes required, as discussed in the following sections. 
Table 11.1 Subcathment Characteristics and Sizing of LID BMPs

\begin{tabular}{|c|c|c|c|c|c|}
\hline \multirow[b]{2}{*}{ SUBCATCHMENT } & \multirow[b]{2}{*}{ SLOPE } & \multirow{2}{*}{$\begin{array}{c}\text { AREA OF } \\
\text { SUBCATCHMENT }\end{array}$} & \multicolumn{3}{|c|}{ AREA OF LID BMP } \\
\hline & & & $\begin{array}{l}\text { INFILTRATION } \\
\text { TRENCH }\end{array}$ & $\begin{array}{l}\text { VEGETATED } \\
\text { SWALE }\end{array}$ & $\begin{array}{l}\text { RETENTION } \\
\text { POND }\end{array}$ \\
\hline S1 & $15.5 \%$ & 17253 & 1725.3 & & \\
\hline S2 & $15.5 \%$ & 5200 & 520 & & \\
\hline S3 & $15.5 \%$ & 32112.7 & 3211.27 & & 2408.45 \\
\hline S4 & $15.5 \%$ & 7900.7 & 790.07 & & 592.55 \\
\hline S5 & $15.5 \%$ & 16513.5 & 1651.35 & & 1238.51 \\
\hline S6 & $15.5 \%$ & 10838 & 1083.8 & & 812.85 \\
\hline S7 & $16.6 \%$ & 3751.8 & 375.18 & & \\
\hline S8 & $16.6 \%$ & 4266.7 & 426.67 & & 320.00 \\
\hline S9 & $9.2 \%$ & 5251 & 525.1 & 477.075 & 393.83 \\
\hline S10 & $9.2 \%$ & 24145.6 & 2414.56 & 1086.675 & \\
\hline S11a & $9.2 \%$ & 5607.9 & 560.79 & 493.2 & 420.59 \\
\hline S11b & $5.7 \%$ & 7151.5 & 715.15 & 754.275 & 536.36 \\
\hline S12a & $9.2 \%$ & 11375.6 & 1137.56 & 708.9 & 853.17 \\
\hline $\mathrm{S} 12 \mathrm{~b}$ & $5.7 \%$ & 3517.6 & 351.76 & 379.575 & \\
\hline S13 & $5.7 \%$ & 855.5 & 85.55 & 178.125 & \\
\hline S14 & $0.5 \%$ & 333 & 33.3 & & \\
\hline S15 & $0.5 \%$ & 2000 & 200 & & \\
\hline S16 & $5.7 \%$ & 5755.5 & 575.55 & 463.725 & \\
\hline S17 & $0.5 \%$ & 2479.2 & 247.92 & & \\
\hline S18 & $0.5 \%$ & 9235.9 & 923.59 & 606.3 & \\
\hline S19 & $0.5 \%$ & 1865.5 & 186.55 & 300.75 & \\
\hline S20 & $0.5 \%$ & 4910.8 & 491.08 & 434.85 & \\
\hline S21 & $0.5 \%$ & 6460.3 & 646.03 & 482.475 & \\
\hline S22 & $0.5 \%$ & 8078.5 & 807.85 & 549.45 & \\
\hline S23 & $0.5 \%$ & 7000 & 700 & 625.875 & 525.00 \\
\hline S24 & $0.5 \%$ & 10539.8 & 1053.98 & & 790.49 \\
\hline
\end{tabular}

Note: The Areas for each LID BMP were used throughout all cases depending on the variation of systems implemented. 


\section{Common Model Inputs}

Rainfall runoff was calculated using the Rational Method Equation as shown in Equation 11.1 below (Wurbs and James 2001).

$$
Q_{p}=C i A
$$

Where: Qp : peak discharge in $\mathrm{m}^{3} / \mathrm{s}$

$$
\begin{aligned}
& \text { C : runoff coefficient } \\
& \text { i : rainfall intensity } \mathrm{cm} / \mathrm{hr}
\end{aligned}
$$

$$
\text { A : drainage area } \mathrm{m}^{2}
$$

Values for runoff coefficient $C$ were obtained from the NRCS Hydrologic Soil Group table (Wurbs and James 2001). Due to the variation in land typology a composite $C$ value was calculated at 0.45 as shown in Table 11.2 below. According to the descriptions of each soil group provided by the US Department of Agriculture, the study site was determined to fall into Group C. These types of soil exhibit high runoff rates after full saturation and between 20 to $40 \%$ of clay (United States Department of Agriculture, 2007). The drainage area was obtained through site measurements and it was known to be 21.44 ha. $\left(214,400 \mathrm{~m}^{2}\right)$.

Table 11.2 Rational Method Composite Coefficient $C$

\begin{tabular}{|l|l|r|r|r|}
\hline \multicolumn{1}{|c|}{ LAND TYPE } & \multicolumn{1}{|c|}{ COMPOSTIE AREA CATEGORY } & AREA(m2) & \% OF AREA & \multicolumn{1}{c|}{ C } \\
\hline Agricultural Area & $\begin{array}{l}\text { Lawns, heavy soil } \\
\text { Steep, 7\% }\end{array}$ & 29453 & $13 \%$ & 0.34 \\
\hline Low Density Residential Area & Residential - Single Family & 128915 & $57 \%$ & 0.4 \\
\hline Medium Density Residential Area & Residential - Multi-units detached & 53552.4 & $24 \%$ & 0.5 \\
\hline Paved Area & Pavement - asphalt and brick & 13532.2 & $6 \%$ & 0.95 \\
\hline & & & COMPOSITE C & 0.45 \\
\hline
\end{tabular}


The Rational Method Equation calls for $i$, rainfall intensity, which may be calculated using the following Equation:

$$
i=\frac{a}{(t+b)^{c}}
$$

Where $a, b$ and $c$ are site specific coefficients and $t$ is the duration of rainfall expressed in minutes. Intensity can also be obtained by referencing site specific IDF curves. Given that this data is not available for the study site, Custer County, CO was chosen as a comparative site given its similar geographical and hydrological qualities to the study site. IDF curves were obtained through the NOAA database from weather station WESTCLIFFE located within Custer County, CO. as shown in Figure 11.2. Intensity, $i$, was determined to be $4 \mathrm{~mm} / \mathrm{hr}$ for a $24 \mathrm{hr}$ storm and a recurrence interval of $10 \mathrm{yrs}$. Soil group classification and descriptions were obtained from the NRCS database for the same location.

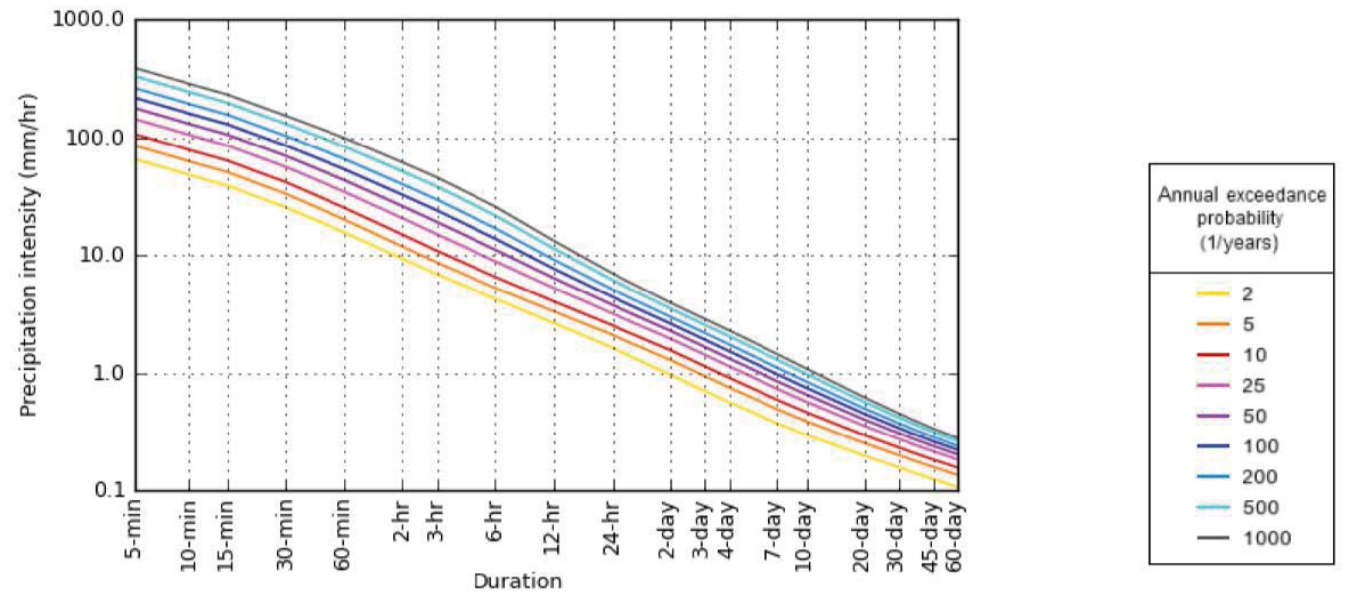

Figure 11.2 IDF Curves for Custer County, CO

Source: NOAA (NOAA 2015)

Using Equation 11.1 the pre-development peak discharge resulted in $0.08 \mathrm{cms}$ and post-development peak discharge resulted in $0.11 \mathrm{cms}$. Post-development value of 
$0.11 \mathrm{cms}$ was used in the design calculations of vegetated swales, infiltration trenches and retention ponds.

\section{Subcatchments}

All of the plots of land which are adjacent to the road were incorporated into the study and are referred to as subcatchments. Subcatchments behave as objects which receive precipitation and generate runoff. Each subcatchment requires user provided inputs for various variables including tag, area, outlet, average slope, percent of impervious surface and LID controls. The following are common values set for all subcatchments: rain gage, Manning's $n$ for pervious and impervious surfaces, depth of depression storage for impervious and pervious surfaces, percent of impervious area with no depression storage, subarea routing, percent routed and infiltration. As per Table 11.3 these were set as follow: Rainfall was input as volume in 24 hour intervals and obtained from the weather station the adjacent city of Chachapoyas. Rainfall data can be referenced in Appendix A: Chachapoyas Rainfall Data. For a Manning's $n$ value of impervious surfaces 0.014 was chosen representing brick with cement mortar and 0.17 to represent pervious surfaces as cultivated soils with $20 \%$ or more of residue cover. These were the best fit for the site characteristics as impervious surfaces are mostly a mix of mud bricks and cement and pervious surfaces are agricultural plots. Depth of depression storage for impervious surfaces was set to $1.778 \mathrm{~mm}$ as a mid-range value for impervious surfaces and $5.08 \mathrm{~mm}$ for pastures as pervious areas. Percent of zero imperviousness was set to $25 \%$ assuming that only that percentage of the impervious area has a depression storage value of zero. Subarea routing was set to outlet to allow runoff from both impervious and pervious areas to flow directly into the outlets. Percent routed was set to $100 \%$ in order to allow the model to process all runoff generated. Infiltration, defined by the Curve Number, was calculated to be a composite 
CN value of 79 with $13 \%$ of the area determined to be fallow Soil Group A with a CN value of 77 , low impervious residential area making up $57 \%$ of the area categorized as Soil Group B with a CN value of 68 , medium impervious residential area making up $24 \%$ of the area categorized as Soil Group C with a CN value of 90 and paved area making up $6 \%$ of the area categorized as Soil Group D and a CN value of 93. Inputs for groundwater, snow pack, land uses, initial buildup and curb length were omitted as they are not considered in this study.

Table 11.3 Common Values for Subcatchment Properties

\begin{tabular}{|c|c|c|}
\hline NAME & VALUE & DESCRIPTION \\
\hline Rain Gage & 925.5 & $\begin{array}{l}\text { Rainfall data collected from weather station located in the } \\
\text { regional capital of Chachapoyas }(\mathrm{mm})\end{array}$ \\
\hline N-Imperv & 0.014 & $\begin{array}{l}\text { Manning'g } \mathrm{n} \text { for overlad flow over the impervious portion of } \\
\text { the subcatchment. }\end{array}$ \\
\hline N-Perv & 0.17 & $\begin{array}{l}\text { Manning'g n for overlad flow over the ipervious portion of the } \\
\text { subcatchment. }\end{array}$ \\
\hline Dstore-Imperv & 1.778 & $\begin{array}{l}\text { Depth of depression storage on the impervious portion of the } \\
\text { subcatchment }(\mathrm{mm})\end{array}$ \\
\hline Dstore-Perv & 5.08 & $\begin{array}{l}\text { Depth of depression storage on the pervious portion of the } \\
\text { subcatchment }(\mathrm{mm})\end{array}$ \\
\hline \%Zero-Imperv & 25 & Percent of the impervious area with no depression storage. \\
\hline Subare Rounting & outlet & areas. \\
\hline Percent Routed & $100 \%$ & Percent of runoff routed between subareas \\
\hline Infiltration & 80 & composite $\mathrm{CN}^{*}$ \\
\hline
\end{tabular}

*Values obtained from Water Resources Engineering by Ralph A. Wurbs

Note: User provided inputs to SWMM in the Subcatchment Property Editor to be used as common values

for all subcatchments. User is able to edit these on a case by case basis as needed.

Plots have been designated as subcatchments and identified as shown in Table 11.4 which also indicates total area in $\mathrm{m}^{2}$ for each. A natural case, intended to represent the natural hydrology of the site, was set up with subcatchments set with $0 \%$ impervious areas and all runoff being routed to one outlet. The other ten cases incorporated variations of LID BMPs - infiltration trenches, vegetated swales and retention ponds. The number of LID BMPs in each case increased from Case 1 to Case 
10, where six LID BMPs were incorporated in Case 1, ten LID BMPs were incorporated in Case 2, fourteen LID BMPs were incorporated in Case 3, fifteen LID BMPs were incorporated in Case 4, twenty-two LID BMPs were incorporated in Cases 5 and 6, twenty four LID BMPs were incorporated in Case 7, twenty five LID BMPs were incorporated in Case 8, twenty seven LID BMPs were incorporated in Case 9 and thirty two LID BMPs were incorporated in Case 10. Detailed tables can be referenced Appendix C: LID BMPs Areas per Case. Detailed diagrams of the layout of LID BMPS per case can be referenced in Appendix B: LID BMPs Identification Diagram per case. Input for vegetated swales, infiltration trenches and retention ponds will be discussed in detail later in this section. A site plan was used as a background image to determine the size and location of all subcatchments. 
Table 11.4 Subcatchment Identification

\begin{tabular}{|c|c|c|}
\hline SUBCATCHMENT & $\begin{array}{c}\text { AREA } \\
(\mathrm{m} 2)\end{array}$ & $\begin{array}{c}\% \\
\text { IMPERVIOUS } \\
\text { AREA }\end{array}$ \\
\hline S1 & 17253 & 25 \\
\hline S2 & 5200 & 25 \\
\hline S3 & 32112.7 & 25 \\
\hline S4 & 7900.7 & 25 \\
\hline S5 & 16513.5 & 25 \\
\hline S6 & 10838 & 25 \\
\hline S7 & 3751.8 & 30 \\
\hline S8 & 4266.7 & 30 \\
\hline S9 & 5251 & 30 \\
\hline S10 & 24145.6 & 30 \\
\hline S11a & 5607.9 & 35 \\
\hline S11b & 7151.5 & 35 \\
\hline S12a & 11375.6 & 35 \\
\hline $\mathrm{S} 12 \mathrm{~b}$ & 3517.6 & 40 \\
\hline S13 & 855.5 & 40 \\
\hline S14 & 333 & 95 \\
\hline S15 & 2000 & 90 \\
\hline S16 & 5755.5 & 70 \\
\hline S17 & 2479.2 & 90 \\
\hline S18 & 9235.9 & 70 \\
\hline S19 & 1865.5 & 70 \\
\hline S20 & 4910.8 & 70 \\
\hline S21 & 6460.3 & 70 \\
\hline S22 & 8078.5 & 70 \\
\hline S23 & 7000 & 25 \\
\hline S24 & 10539.8 & 70 \\
\hline
\end{tabular}




\section{Junctions and Conduits}

Conduits join subcatchments to junctions (aka nodes) and allow for runoff to be routed to a specified outlet. User provided inputs used as common values for both can be referenced on Table 11.5

Table 11.5 Common Values for Junctions and Conduits

\begin{tabular}{|c|c|c|}
\hline NAME & VALUE & DESCRIPTION \\
\hline Conduit Geometry & Circular & \\
\hline Conduit Roughness & 0.01 & Manning'g n - Open channel concrete \\
\hline Flow Units & CMS & Cubic Meters per Second \\
\hline Link Offsets & Depth & $\begin{array}{l}\text { Depth of conduit invert above the node } \\
\text { invert at the upstream and downstream } \\
\text { end of the conduit. }(\mathrm{m})\end{array}$ \\
\hline Routing Method & Dynamic Wave & \\
\hline Force Main Equation & Darcy-Weishbach & \\
\hline
\end{tabular}

Note: Values provided to SWMM in the Project Default Editor to be used as common values for all junctions and conduits. User is able to edit these on a case by case basis if needed.

All conduits were set to have a circular geometry. The conduit roughness was set to 0.01 to represent Manning's $n$ value for concrete lined open channels. Flow units were calculated in cms. Link offsets were calculated by depth rather than elevation. The Dynamic Wave Method was chosen as the default routing method and the DarcyWeisbach Equation as the force main equation denoted in Equation 11.3 below. 


$$
H_{L}=f \frac{L}{D} \frac{V^{2}}{2 g}
$$

Where: $\mathrm{H}_{\mathrm{L}}=$ Headloss

$$
\begin{aligned}
& f=\text { friction factor } \\
& L=\text { length of the pipe } \\
& D=\text { diameter of the pipe } \\
& V=\text { velocity } \\
& g=\text { gravity }
\end{aligned}
$$

Invert elevation values were provided for each junction as shown in Table 11.6 below with junction $\mathrm{J} 1$ being the highest at an elevation of 1990 meters and junction J 14 the lowest at an elevation of 1903 meters.

Table 11.6 Junction Inputs

\begin{tabular}{|c|c|}
\hline JUNCTION & $\begin{array}{c}\text { INVERT ELEVATION } \\
(\mathbf{m})\end{array}$ \\
\hline $\mathrm{J1}$ & 1990 \\
\hline $\mathrm{J} 2$ & 1980 \\
\hline $\mathrm{J} 3$ & 1975 \\
\hline $\mathrm{J} 4$ & 1950 \\
\hline $\mathrm{J} 5$ & 1942 \\
\hline $\mathrm{J} 6$ & 1935 \\
\hline $\mathrm{J} 7$ & 1932 \\
\hline $\mathrm{J} 8$ & 1918 \\
\hline $\mathrm{J} 9$ & 1915 \\
\hline $\mathrm{J} 10$ & 1909 \\
\hline $\mathrm{J} 11$ & 1907 \\
\hline $\mathrm{J} 12$ & 1906.5 \\
\hline $\mathrm{J} 13$ & 1905 \\
\hline $\mathrm{J} 14$ & 1903 \\
\hline
\end{tabular}


Conduits lengths were input as per Table 11.7 Conduit Inputs below.

Table 11.7 Conduit Inputs

\begin{tabular}{|c|c|} 
CONDUIT & $\begin{array}{c}\text { LENGTH } \\
(\mathrm{m})\end{array}$ \\
\hline $\mathrm{C} 1$ & 243.48 \\
\hline $\mathrm{C} 2$ & 57.1 \\
\hline $\mathrm{C} 3$ & 186.3 \\
\hline $\mathrm{C} 4$ & 61.53 \\
\hline $\mathrm{C} 5$ & 71.38 \\
\hline $\mathrm{C} 6$ & 42.26 \\
\hline $\mathrm{C} 7$ & 135.66 \\
\hline $\mathrm{C} 8$ & 71.45 \\
\hline $\mathrm{C} 9$ & 99.24 \\
\hline C10 & 47.79 \\
\hline C11 & 77.22 \\
\hline C12 & 90.08 \\
\hline C13 & 76.3 \\
\hline C14 & 20 \\
\hline
\end{tabular}

\section{Low Impact Development BMP Systems}

SWMM has the capability to model retention ponds, porous pavements, infiltration trenches, rain barrels and vegetative swales. For the purpose of this study, infiltration trenches, vegetated swales and retention ponds were used. Based on geography, availability of materials, low operation and maintenance demands and land use these were chosen as the most appropriate systems.

Under the LID Usage editor the option to return outflow from LID was not selected so that any outflow can be routed to the subcatchment's outlet.

The sizing of all LID BMPs was determined by the contributing are of runoff of the subcatchment where they were implemented. Therefore, all LID BMPs vary in area. 


\section{Infiltration Trenches}

Areas for infiltration trenches in each subcatchment were calculated as follows: First, runoff volume, $V_{r}$, was calculated for each subcatchment using Equation 11.4 below (Barkdoll and Watkins 2009). Rainfall depth, Ds, was set at a value of $3 \mathrm{~cm}$.

$$
V_{r}=A_{c} D_{f}
$$

Where: $V_{r}$ : volume of runoff

$$
\begin{aligned}
& A_{c} \text { : contributing area } \\
& D_{f} \text { : rainfall depth }
\end{aligned}
$$

Equation 11.5 (Barkdoll and Watkins 2009) was used as the basis for Equation 11.6 which was used to calculate the area, $L W$, needed for each infiltration trench.

$$
\begin{gathered}
S S=n H W L \\
L W=S S / n H
\end{gathered}
$$

Where: LW : surface area of infiltration trench

$$
\begin{aligned}
& \mathrm{S}_{\mathrm{s}} \text { : storage volume } \\
& \mathrm{n} \text { : porosity of gravel, as a percent } \\
& \mathrm{H} \text { : depth of the gravel fill }
\end{aligned}
$$

Infiltration trenches are most effective in reducing surface runoff volume. Therefore storage volume, $S_{s}$, was used to calculate its area. This calculation was determined by 
the volume runoff, $V_{r}$, obtained from Equation 11.4. A mix of sand and gravel with a porosity $n$ value of $20 \%$ (Wurbs and James 2001) was assumed as a design parameter due its local availability. Depth of gravel fill, $H$, was set to $1.5 \mathrm{~m}$.

Appendix C: LID BMPs Areas per Case can be referenced for areas of each infiltration trench. Figure 11.3 depicts a diagram of an infiltration trench identifying its main components.

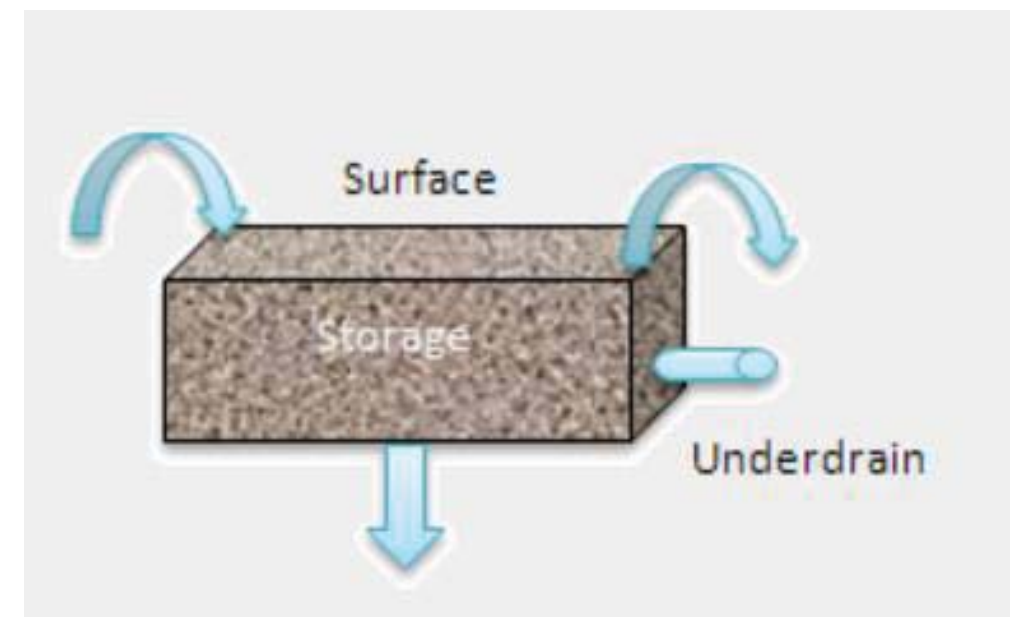

Figure 11.3 Infiltration Trench Diagram

Source: SWMM 5.1 Screen capture from LID Control Editor Window

Suggested widths for infiltration trenches are 0.9-2.4 meters (3-8 feet) and stone fill depth is suggested to be set at 1.8 meters ( 6 feet) depth (Department of Environmental Protection, Bureau of Watershed 2006). A berm has been incorporated into the design of the infiltration trench in order to allow ponding and facilitate infiltration at a slow rate. Berm height was calculated using Equation 11.7:

$$
d=\frac{S_{s}}{L W}
$$


Where: $d$ = depth of berm

$$
\begin{aligned}
& \mathrm{S}_{\mathrm{s}}=\text { storage volume } \\
& \mathrm{LW}=\text { surface area }
\end{aligned}
$$

The LID Control Editor requires inputs for surface, storage and underdrain. A summary of user provided inputs can be referenced in Table 11.8. Common values for the surface layer were set as follows: Berms were sized to $152.40 \mathrm{~mm}$ in order to allow slow infiltration. Vegetation volume fraction, defined as the fraction of the storage area that is filled with vegetation, is set to 0.9. Surface roughness and slope were not accounted for infiltration trenches. Values for the storage layer were set as follows: Thickness of the gravel layer, void ratio and seepage rate were set to $450 \mathrm{~mm}, 0.75$ and $750 \mathrm{~mm} / \mathrm{hr}$ respectively, as recommended (EPA 2015). Values for the underdrain layer were set as follows: Flow coefficent, $C$, was set to 1.86 and caculated using Equation 11.8 (EPA 2015). Flow exponent, $n$, was set to 0.5 as sugested by the SWMM Manual. Offset height was $450 \mathrm{~mm}$ given the depth of the infiltration trench. Recommendations call for a mimun of 6 hours for proper drainage (EPA 1999). Ideally, systems will be able to drain before the next rainstorm. 


$$
C=2 D^{1 / 2} / T
$$

Where: $\mathrm{C}=$ drain coefficient

$\mathrm{D}=$ depth of water to be draines

$\mathrm{T}=$ draining time required

Table 11.8 Common Values for Infiltration Trenches

\begin{tabular}{|c|c|c|}
\hline DESCRIPTION & VALUE & UNITS \\
\hline \multicolumn{3}{|l|}{ SURFACE } \\
\hline Berm Height & 152.4 & $\mathrm{~mm}$ \\
\hline Vegetation Volume & 0.9 & \\
\hline Surface Roughness & $\mathrm{n} / \mathrm{a}$ & \\
\hline Surface Slope & $\mathrm{n} / \mathrm{a}$ & \\
\hline \multicolumn{3}{|l|}{ STORAGE } \\
\hline Thickness & 450 & $\mathrm{~mm}$ \\
\hline Void Ratio & 0.75 & voids/ solids \\
\hline Seepage Rate & 750 & $\mathrm{~mm} / \mathrm{hr}$ \\
\hline Clogging Factor & 0 & note: parameter not used \\
\hline \multicolumn{3}{|l|}{ UNDERDRAIN } \\
\hline Flow Coefficient & 1.86 & $\mathrm{~mm} / \mathrm{hr}$ \\
\hline Flow Exponent & 0.5 & \\
\hline Offset Height & 450 & $\mathrm{~mm}$ \\
\hline
\end{tabular}

Source: SWMM 5.1 LID Control Editor - Infiltration Trench

\section{Vegetated Swales}

Vegetated swales require the following inputs: discharge that the swale must pass, site characteristics such as slopes - both longitudinal and side slope - and the 
vegetation roughness used to line the swale. A vegetated swales diagram can be reference below in Figure 11.4.

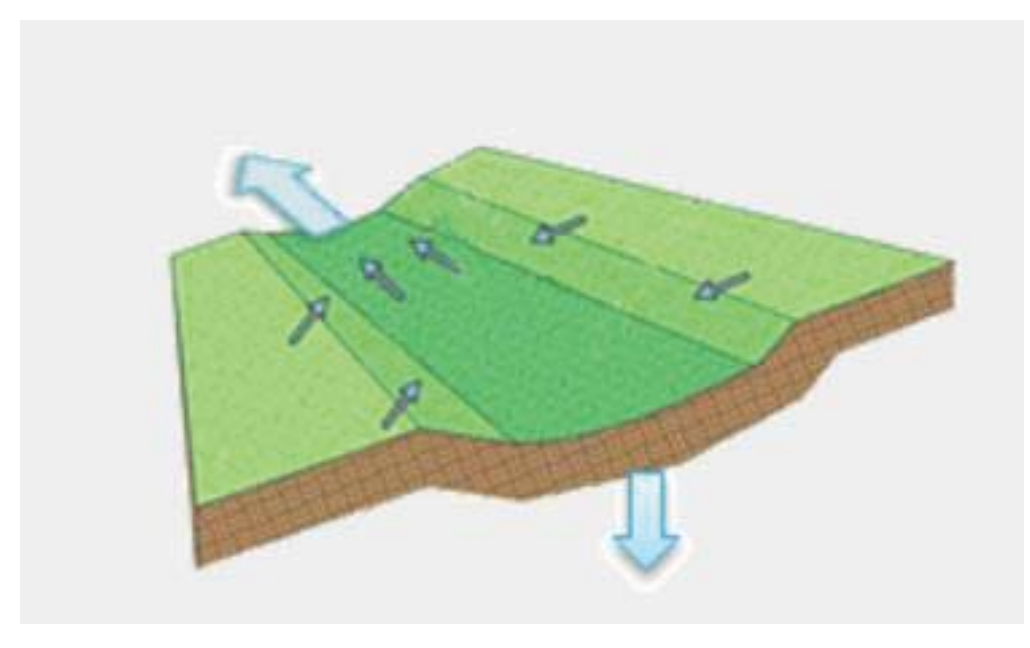

Figure 11.4 Vegetated Swale Diagram

Source: SWMM 5.1 Screen capture from LID Control Editor Window

Allowable discharge was calculated based on Manning's Equation using Equation 11.9 below (Barkdoll and Watkins 2009). Peak allowable discharge was found to be 0.14 cms. Parameters and values used to obtain this value are explained below. 


$$
Q=\frac{C m}{n} A R^{2 / 3} S^{1 / 2}
$$

Where: $\mathrm{Q}=$ allowable discharge

$$
\begin{aligned}
& \mathrm{Cm}=1.0 \text { (SI Units) } \\
& \mathrm{n}=0.15 ; \text { grass roughness coefficient } \\
& \mathrm{A}=\text { area of swale (see Equation } 11.10 \text { ) } \\
& \mathrm{R}=\text { hydraulic radius (see Equation } 11.11 \text { ) } \\
& \mathrm{S}=\text { longitudinal slope as percent }
\end{aligned}
$$

$\mathrm{Cm}$ value of 1.0 was given as all calculations were set to metric units. A Manning's overland flow $n$ value of 0.15 represents short grass (EPA 2015). The area, $A$, required for the swale was calculated using Equation 11.10 below (Barkdoll and Watkins 2009).

$$
A=z d^{2}
$$

Where: $A=$ cross section area of swale

$$
\begin{aligned}
& z=\text { side slope as ratio } \\
& d=\text { depth of swale }
\end{aligned}
$$


Equation 11.11 was used to calculate hydraulic radius, $R_{h}$, (Barkdoll and Watkins 2009).

$$
R_{h}=0.5 z d\left(1+z^{2}\right)^{\wedge}-0.5
$$

Where: $\mathrm{R}_{\mathrm{h}}=$ radius

$$
\begin{aligned}
& z=\text { side slope } \\
& d=\text { depth of swale }
\end{aligned}
$$

Side slope, $z$, was set to 3:1 and depth of swale, $d$, was set to 1 meter. Both of these values were determined based on technical recommendations (EPA 1999).

Given that the site's current post-development peak flow is $0.11 \mathrm{cms}$ the resulting 0.14 cms allowable discharge for vegetated swales would allow for their implementation.

Common input values provided by the user were set as follows: Berm height was set to $300 \mathrm{~mm}$. Vegetation volume value, defined as the fraction of storage area above the surface that is filled (EPA 2015) was set to 0.9. Manning's overland flow $n$ value of 0.15 represents short grass (EPA 2015). Surface slope, defined as the longitudinal slope and expressed as a percent, was set to 0.04 , which is the maximum recommended in order to avoid system failure (EPA 1999). Swale side slope, defined as slope (run over rise) of a vegetative swale's cross section (EPA 2015), was set to 3, as to represent a 3:1 side slope. Common inputs can be viewed in Table 11.9 below. 
Table 11.9 Common Values for Vegetated Swales

\begin{tabular}{|c|c|c|}
\hline DESCRIPTION & VALUE & UNITS \\
\hline \multicolumn{3}{|l|}{ SURFACE } \\
\hline Berm Height & 152.4 & $\mathrm{~mm}$ \\
\hline Vegetation Volume & 0.9 & \\
\hline Surface Roughness & 0.15 & Manning's n \\
\hline Surface Slope & 0.04 & \\
\hline Swale Side Slope & 3 & run/rise \\
\hline
\end{tabular}

Source: SWMM 5.1 LID Control Editor - Vegetated Swales

\section{Retention Ponds}

Design parameters for retention ponds include the surface area, vegetation, storage volume, infiltration and underdrain. These parameters are presented as a diagram in Figure 11.5.

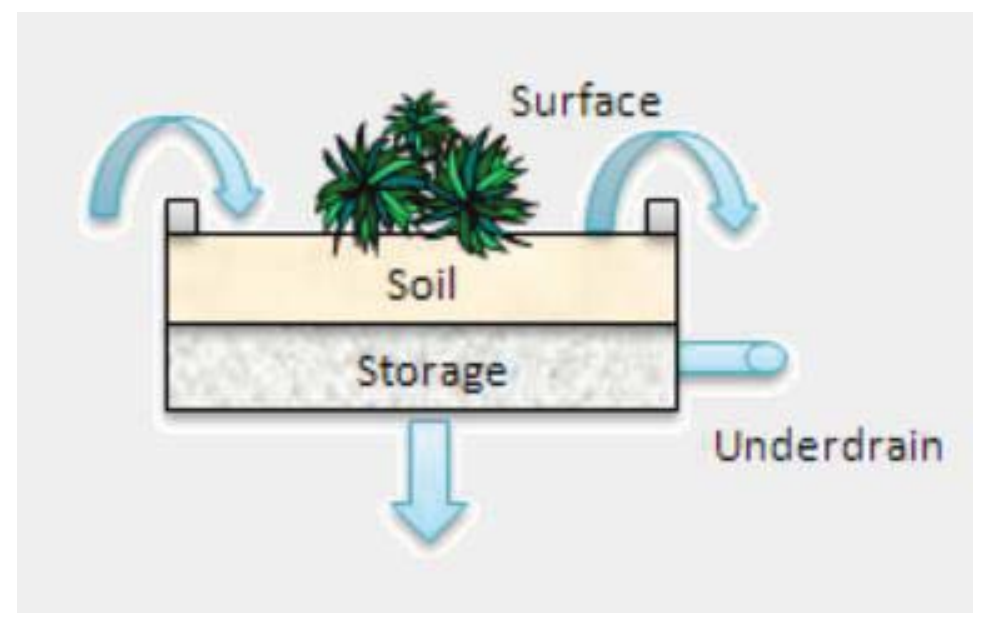

Figure 11.5 Retention Pond Diagram

Source: SWMM 5.1 Screen capture from LID Control Editor Window 
Pond surface area was calculated using Equation 11.12 (Barkdoll and Watkins 2009).

$$
A_{s}=\frac{D_{f} A_{c}}{d_{s}\left(1-f_{v}\right)}
$$

Where: $A_{s}=$ surface area

$$
\begin{aligned}
& D_{f}=\text { depth of rainfall } \\
& A_{c}=\text { contributing area } \\
& d_{s}=\text { pond depth } \\
& f_{v}=\text { vegetation density }
\end{aligned}
$$

Depth of rainfall, $D_{f}$, was set to $0.03 \mathrm{~m}$. The area of each subcatchment was considered to be contributing area, $A_{c}$. Pond depth, $d_{s}$, was set to $0.5 \mathrm{~m}$ and vegetation density was set to 0.9 . Retention pond areas can be referenced in

\subsection{WERF Cost Models}

\subsubsection{Introduction}

The Water Environment Research Foundation (WERF) in collaboration with United Kingdom Water Industry Research (UKWIR) and the Environmental Protection Agency, have developed models to facilitate the calculation of cost for various stormwater management systems. The WERF models have been developed with focus on practices in developed countries. For the purpose of this study, which focuses on the implementation of LID BMPs in a semi-urban community of a developing country, the WERF models for vegetated swales and retention ponds have been used as guide to calculate costs for the implementation of infiltration trenches, vegetated swales and 
retention ponds. The models have been adjusted to better suit the circumstances of implementing and maintaining the aforementioned LID BMP systems in a rural setting.

\subsubsection{Methodology}

A conversion rate of S/. 2.80 Soles, the local currency of Perú, to $\$ 1.00$ for ease of calculations. All results were reported in dollar amounts.

Areas for each LID BMP were calculate based on the area $\left(\mathrm{m}^{2}\right)$ of the subcatchment they were placed in. Given that each LID BMP requires different areas, a base cost per $\mathrm{m}^{2}$ was calculated and then multiplied by the required area.

Each LID BMP, is referred to as a facility. The total cost of each facility has three main component - engineering cost and maintenance cost. The capital cost include costs for construction and educational materials required for each facility. Engineering cost were set at a default of $25 \%$ of the capital cost for each facility as recommended (WERF 2009). Maintenance cost account for wages and were calculate for a 10 year period given the effective lifespan of LID BMPs. Routine maintenance cost calculations have been set to the lowest level possible as it will be more feasible for land owners and municipality staff to adopt technologies that do not require high levels of maintenance. The typical hourly wage for skilled labor is $\$ 0.36$ per hour. Costs for machinery were not included as it is assumed that there will not be access to machinery. Maintenance costs include hourly wages for skilled workers. Non-skilled activities are to be carried out by landowners during both the construction and maintenance phases at no cost.

Land costs were not included as there are many options for the placement of these LID BMPs, such as land owned privately, by the community or by the local authorities. Additionally, for the purposes of design, SWMM 5.1 does not take into consideration the exact location of the LID BMP within the subcatchment, but rather the amount of 
runoff it is required to handle. Therefore they could potentially be located in areas owned by local authorities and thus contributed as part of the project at no cost.

It is important to note that cost for educational materials and technical trainings are of the highest importance given that many systems fail due to lack of knowledge on operation and maintenance.

\subsection{Maintenance Probability Factor}

Given the observations made by the author during the data collection phase, an elementary method of categorization has been developed and carried out. The Maintenance Probability Factor (MPF) is defined as the probability each subcatchment presents for the maintenance of LID BMPs. Each subcatchment was categorized by land use under four categories - agricultural, low residential density, medium residential density and institutional. Each of these categories was then expressed with

1, for agricultural subcatchments; 2 for low density residential; 3 for medium density residential and 4, for institutional. On a case by case basis all subcatchment land use values were averaged in order to obtain an MPF for each case. Figure 11.6 showcases the location of each subcatchment with land use types coded in color. It is important to note that these values are not quantitative in the sense that a value of 2 , for a low residential category, would be twice as unlikely to maintain the systems when compared to subcatchments categorized as an agricultural subcatchment with a value of 1 . Instead, they help to give each case - composed of various subcatchments with different land use categories - a value by which to gage the probability of maintenance per case. Detailed data would have to be taken to fully quantify these MPF values. Detailed tables with MPF values for each case may be referenced in Appendix D: Maintenance Probability Factor (MPF) . 


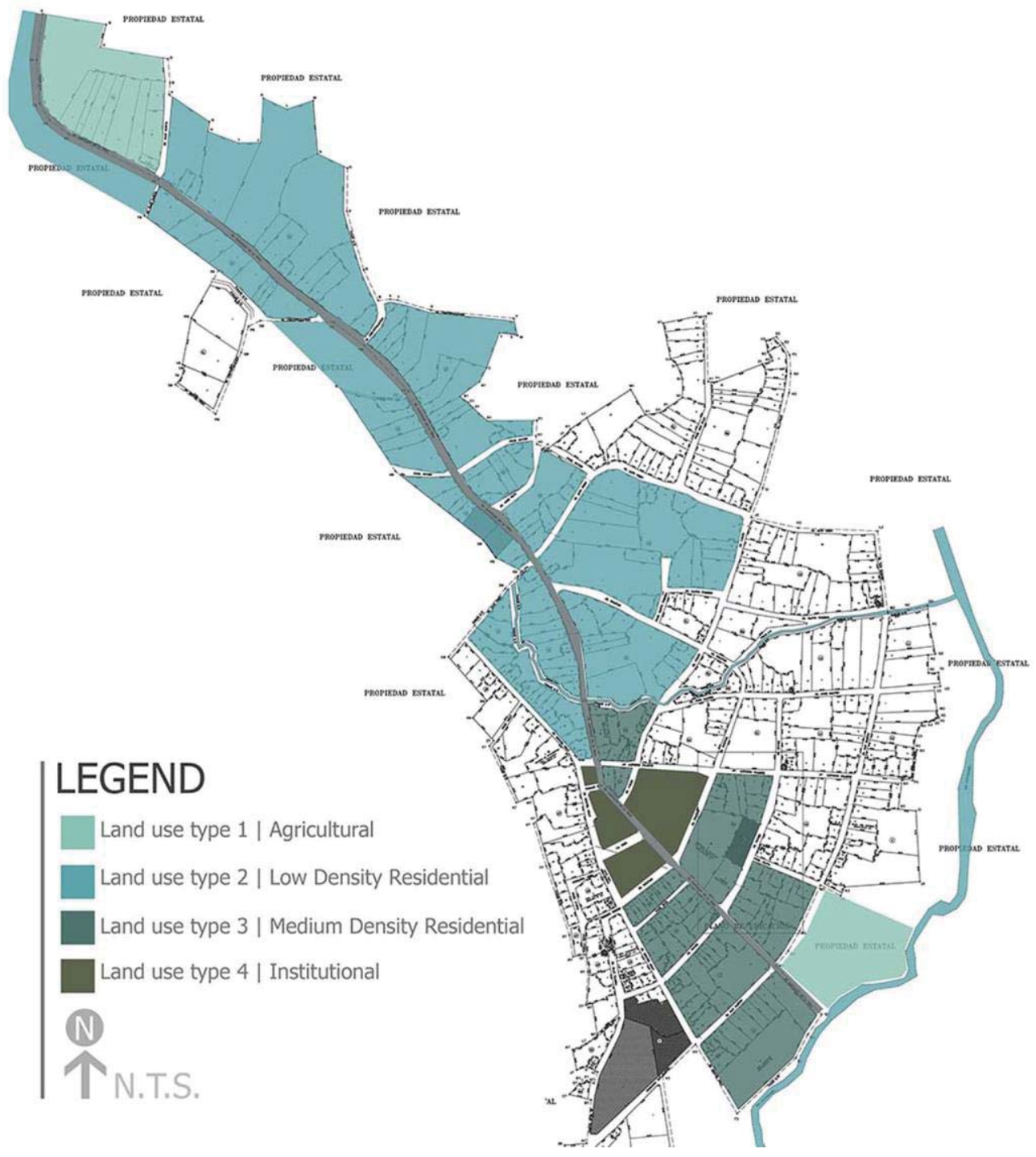

Figure 11.6 Site Plan of Lámud with Land Use Categories

Note: Map showcases land use category of each subcatchment denoted by color. See legend in map for color references and values. 


\section{Results}

\subsection{SWMM 5.1 Results}

The natural case resulted in a runoff of $19596.96 \mathrm{~mm}, Q_{\text {nat. }}$ Results for the 10 cases were compared to the natural runoff and then ranked to find which of the cases came closest to returning runoff to its natural level. Appendix E: SWMM 5.1 Runoff Results contains detailed tables of runoff totals for each case and shows the difference in runoff for each subcatchment throughout all cases. Cases were ranked based on the difference between the natural runoff value, $Q_{n a t}$, and the runoff value for each case, Qro. The results show that Case 1 resulted in being the scenario which brought the runoff closest to the Natural Case by a difference of $699.22 \mathrm{~mm}$ as seen in Table 12.1. The LID BMPs included in this case were infiltration trenches in subcatchments S12b, S13, S16, S18 and S21 and a retention pond in subcatchment S23. Whereas Case 6, which is using more LID BMPs resulted in increasing runoff by a difference of 2769.78 $\mathrm{mm}$. Though Cases 7, 8, 9 and 10 all decreased the runoff compared to the natural case, they did not rank highly because the difference in their runoff was larger and thus further from the target runoff of $19596.96 \mathrm{~mm}$.

It is important to note that SWMM does not account for flooding probabilities based on the elevation of the subcatchment. Therefore, it is unclear if subcatchments downstream would be more likely to flood in relation to subcatchments upstream and therefore gage which landowners would be more likely to implement and maintain the BMPs. 
Table 12.1 Ranking of Cases Based on Proximity to Natural Case

\begin{tabular}{|c|c|c|c|}
\hline RANKING & CASE & $\begin{array}{l}\text { RUNOFF } \\
(\mathrm{mm})\end{array}$ & $\begin{array}{l}\text { Qnat-Qro } \\
\text { (mm) }\end{array}$ \\
\hline \multicolumn{2}{|c|}{ NATURAL RUNOFF = } & 19596.96 & \\
\hline 1 & 1 & 20296.18 & 699.22 \\
\hline 2 & 2 & 20358.66 & 761.70 \\
\hline 3 & 3 & 20416.67 & 819.71 \\
\hline 4 & 5 & 21397.05 & 1800.09 \\
\hline 5 & 4 & 22358.13 & 2761.17 \\
\hline 6 & 6 & 22366.74 & 2769.78 \\
\hline 7 & 8 & 15890.07 & -3706.89 \\
\hline 8 & 9 & 15775.43 & -3821.53 \\
\hline 9 & 10 & 15105.07 & -4491.89 \\
\hline 10 & 7 & 14909.81 & -4687.15 \\
\hline
\end{tabular}

\subsection{Cost Model Results}

Using the WERF models as a basis (WERF 2009) to identify materials and maintenance options for each of the three LID BMPs costs were calculated for initial and maintenance cost over ten years. I nitial cost is defined as the cost required to design and build the facility for the first time. Maintenance cost is defined as the cost required for the clearing out and replacement of materials as needed. Detailed tables can be referenced in Appendix H: Total Cost of LID BMPs by Case. A summary of the cost of each case can be seen in Table 12.2 below. Total costs ranged between $\$ 129,157.15$ and $\$ 938,394.49$ and in general increased as more LID BMPs were incorporated. When comparing Case 6 and 7 initial and maintenance costs decreased despite the addition of LID BMPs to case 7 from 22 systems in Case 6 to 24 systems in Case 7. This can be attributed to fact that Case 6 mostly has vegetated swales whereas Case 7 incorporates infiltration trenches. When comparing the costs per square meter of vegetated swales and infiltration trenches, vegetated swales resulted in a total higher 
cost per square meter at $\$ 33.40$ vs. $\$ 35.90$ of infiltration trenches. However, infiltration trenches require larger areas and thus result in higher costs. Appendix $\mathrm{H}$ : Total Cost of LID BMPs by Case may be referenced for a detailed list of the costs of LID BMPs implemented in each case.

Table 12.2 Total Cost Results by Case

\begin{tabular}{|c|c|c|c|c|}
\hline CASE & INITIAL COST & \multicolumn{2}{|c|}{$\begin{array}{l}\text { MAINTENANCE } \\
\text { COST } \\
\text { OVER } 10 \text { YRS. }\end{array}$} & \multirow{2}{*}{$\begin{array}{l}\text { TOTAL COST } \\
\$ 129,157.15\end{array}$} \\
\hline 1 & $\$ 43,835.79$ & $\$$ & $85,321.36$ & \\
\hline 2 & $\$ 65,354.30$ & $\$$ & $127,629.24$ & $\$ 192,983.54$ \\
\hline 3 & $\$ 112,575.11$ & $\$$ & $233,516.98$ & $\$ 346,092.09$ \\
\hline 4 & $\$ 111,395.22$ & $\$$ & $239,760.35$ & $\$ 351,155.57$ \\
\hline 5 & $\$ 188,010.10$ & $\$$ & $384,861.14$ & $\$ 572,871.24$ \\
\hline 6 & $\$ 163,240.73$ & $\$$ & $515,402.53$ & $\$ 678,643.26$ \\
\hline 7 & $\$ 215,609.21$ & $\$$ & $396,087.55$ & $\$ 611,696.76$ \\
\hline 8 & $\$ 216,660.08$ & $\$$ & $423,974.82$ & $\$ 640,634.91$ \\
\hline 9 & $\$ 270,530.29$ & $\$$ & $533,411.95$ & $\$ 803,942.24$ \\
\hline 10 & $\$ 320,555.64$ & $\$$ & $617,838.85$ & $\$ 938,394.49$ \\
\hline
\end{tabular}

\section{Infiltration Trenches}

Infiltration trenches resulted in an initial cost of $\$ 12.95$ per square meter. Routine maintenance was the same as for vegetated swales with inspection, reporting and information management to be performed every 36 months was $\$ 0.71$ per square meter; vegetation management with trash and minor debris removal to be performed every 36 months was $\$ 2.86$ per square meter and corrective maintenance was $\$ 11.43$ per square meter to be performed every 120 months. An infiltration trench in subcatchment S16 with an area of $575.55 \mathrm{~m}^{2}$ has an initial cost of $\$ 7,451.81$ with no additional cost for the first, second, fourth, fifth, seventh and eighth year, $\$ 2,054.71$ on the third, sixth and ninth years and $\$ 6,578.54$ on the tenth year for a total cost of $\$ 12,742.68$ in maintenance cost and a total cost of $\$ 20,194.49$ for 10 years. 


\section{Vegetated Swales}

Vegetated swales resulted in an initial cost of $\$ 11.26$ per square meter. Routine maintenance of inspection, reporting and information management to be performed every 36 months was $\$ 0.71$ per square meter, vegetation management with trash and minor debris removal to be performed every 36 months was $\$ 2.86$ per square meter and corrective maintenance was $\$ 11.43$ per square meter to be performed every 120 months. A vegetated swale in subcatchment S10 with an area of $1086.675 \mathrm{~m}^{2}$ will have an initial cost of $\$ 12,236.81$, with no additional cost for the first, second, fourth, fifth, seventh and eighth year, $\$ 3,879.43$ on the third, sixth and ninth years and $\$ 12,420.70$ on the tenth year for a total cost of $\$ 24,058.98$ in maintenance cost and a total cost of $\$ 36,295.80$ for 10 years.

\section{Retention Ponds}

Retention ponds resulted in an initial cost of $\$ 18.57$ per square meter. Routine maintenance cost for inspection, reporting and information management which is to be performed every 36 months would cost $\$ 0.71$ per square meter. Vegetation management with trash and minor debris removal performed every 12 months will cost $\$ 1.43$ per square meter and vector control to be performed every 36 months would cost $\$ 1.43$ per square meter. Corrective and infrequent maintenance such as intermittent facility maintenance (excluding sediment removal) will cost $\$ 2.86$ and is suggested to be performed every 12 months, sediment dewatering \& removal of the forebay to be performed every 96 months would cost $\$ 1.43$ and lastly sediment dewatering and removal of the main pool to be performed every 240 months would cost $\$ 1.43$ per square meter. For instance, the retention pond in subcatchment S3 with an area of $2408.45 \mathrm{~m}^{2}$ would have an initial cost of $\$ 44,730.43$, with additional cost of $\$ 10,332.25$ on the first, second, fifth, seventh, and tenth years, $\$ 15,486.33$ 
on the third, sixth and ninth years, $\$ 13,776.33$ on the fourth year and $\$ 17,220.42$ on the eighth year with a total of $\$ 129,117.00$ for maintenance over 10 years and a total cost of $\$ 173,847.44$.

\subsection{Maintenance Probability Factor Results}

The probability of maintenance for these systems was measured by giving a numerical value to the type of land use for each subcatchment. The values given were as follows: Agricultural, 1; Low Residential 2, Medium Residential, 3; and Institutional, 4. Therefore, the lower the average score is, the higher the probability of long term maintenance of the systems will bew. Table 12.3 below shows the ranking of each simulation based on their land use average score with Case 10 being the most likely to be maintained and Case 1 being the least likely. It is important to note that the number of subcatchments using LID BMPs increases throughout every case as does the number of subcatchments where LID BMPs are likely to be maintained. However, we can see that Cases 5 and 6 would be more likely to be maintained than Cases 7, 8 and 9 even though the latter incorporate more LID BMPs. This can be attributed to the fact that these Cases 5 and 6 incorporate more subcatchments categorized as low residential density. 
Table 12.3 LID BMP Maintenance Probability Factor Ranking

\begin{tabular}{|c|c|c|}
\hline RANKING & CASE & MPF \\
\hline 1 & 10 & 2.38 \\
\hline 2 & 5 & 2.41 \\
\hline 2 & 6 & 2.41 \\
\hline 3 & 9 & 2.48 \\
\hline 4 & 8 & 2.52 \\
\hline 5 & 7 & 2.54 \\
\hline 6 & 4 & 2.60 \\
\hline 7 & 3 & 2.64 \\
\hline 8 & 2 & 2.90 \\
\hline 9 & 1 & 3.17 \\
\hline
\end{tabular}

Subcatchments of agricultural use tend to have higher routine maintenance as they are fallowed on a seasonal basis. Whereas soils on the plots of residential or institutional use are not maintained on a regular basis. Based on this observation, it is assumed that subcatchments with higher percentages of agricultural subcatchment would be most likely to adopt and maintain LID BMPs. Detailed tables with MPF values for each case may be referenced in Appendix D: Maintenance Probability Factor (MPF)

It is important to note that these values are not quantitative in the sense that a value of 2, for a low residential category, would be twice as unlikely to maintain the systems when compared to subcatchments categorized as an agricultural subcatchment with a value of 1 . Instead, they help to give each case - composed of various subcatchments with different land use categories - a value by which to gage the probability of maintenance per case. Agricultural subcatchments are more likely to be managed by land owners and thus represent a higher probability of maintenance and long term effectiveness for the LID BMPs since landowners would be more willing to perform the manual labor required for maintenance. Whereas the institutional subcatchments are 64 
less likely to maintain these systems given that they are leased or owned by institutions who do not necessarily participate in agricultural practices or activities related to working the land on a regular basis and therefore would be less likely to perform the manual labor required for maintenance.

\subsection{Discussion}

Result analysis focused on finding the cost of "benefit", denoted as the Cost Benefit Ratio ( $C B R$ ), with benefit being defined as the ratio of the cost to the percent of runoff reduction as defined by Equation 12.1. Ideally, the lowest value of $C B R$ would be the most cost effective option.

$$
C B R=\frac{C}{\left[\left(Q_{\text {road }}-Q_{\text {roo }}\right) /\left(Q_{\text {road }}-Q_{\text {nat }}\right)\right] * 100}
$$

Where: $\mathrm{CBR}=$ cost benefit ratio

$$
\begin{aligned}
& C=\text { cost per case } \\
& \text { Qroad }=\text { runoff of road case (no LID) } \\
& Q_{\text {nat }}=\text { runoff of natural case } \\
& \text { Qro }_{\text {r }} \text { runoff of case }
\end{aligned}
$$


Table 12.4 Ranking of Cases Base on CBR

\begin{tabular}{|c|c|c|c|c|}
\hline RANKING & CASE & Qro & COST & $\begin{array}{c}\text { CBR } \\
(\$ / \%)\end{array}$ \\
\hline 1 & 1 & 20296.18 & $\$ 129,157.15$ & 1,672 \\
\hline 2 & 7 & 14909.81 & $\$ 611,696.76$ & 2,421 \\
\hline 3 & 2 & 20358.66 & $\$ 192,983.54$ & 2,567 \\
\hline 4 & 8 & 15890.07 & $\$ 640,634.91$ & 2,902 \\
\hline 5 & 9 & 15775.43 & $\$ 803,942.24$ & 3,581 \\
\hline 6 & 10 & 15105.07 & $\$ 938,394.49$ & 3,810 \\
\hline 7 & 3 & 20416.67 & $\$ 346,092.09$ & 4,722 \\
\hline 8 & 5 & 21397.05 & $\$ 572,871.24$ & 13,848 \\
\hline 9 & 4 & 22358.13 & $\$ 351,155.57$ & 34,888 \\
\hline 10 & 6 & 22366.74 & $\$ 678,643.26$ & 69,357 \\
\hline
\end{tabular}

Note: The best case is based on the lowest value of CBR

Table 12.4 above ranks each case based on its CBR value. When analyzing the results based on CBR, Case 1 ranks first with a CBR value of 1,672 resulting in the best case of cost over benefit. With the assumption that more LID BMPs would be better in achieving the natural runoff, $Q_{n a t}$, given their ability to control runoff, it is important to note that it is not the case as it can be showcased when comparing Cases 2 and 6. Where Case 2 ranks in third place, versus tenth place as in Case 6 despite its use of more LID BMPs.

CBR allows us to define a relationship between the benefit - runoff - and cost, seen in Table 12.4. In order to incorporate the third aspect - social - values of CBR and MPF have been plotted to better understand their relationship and identify a level of optimization for both. Table 12.3 ranks cases based on MFP values per case. Figure 12.1 showcases the trend that occurs when trying to optimize both variables - CBR and MFP. 


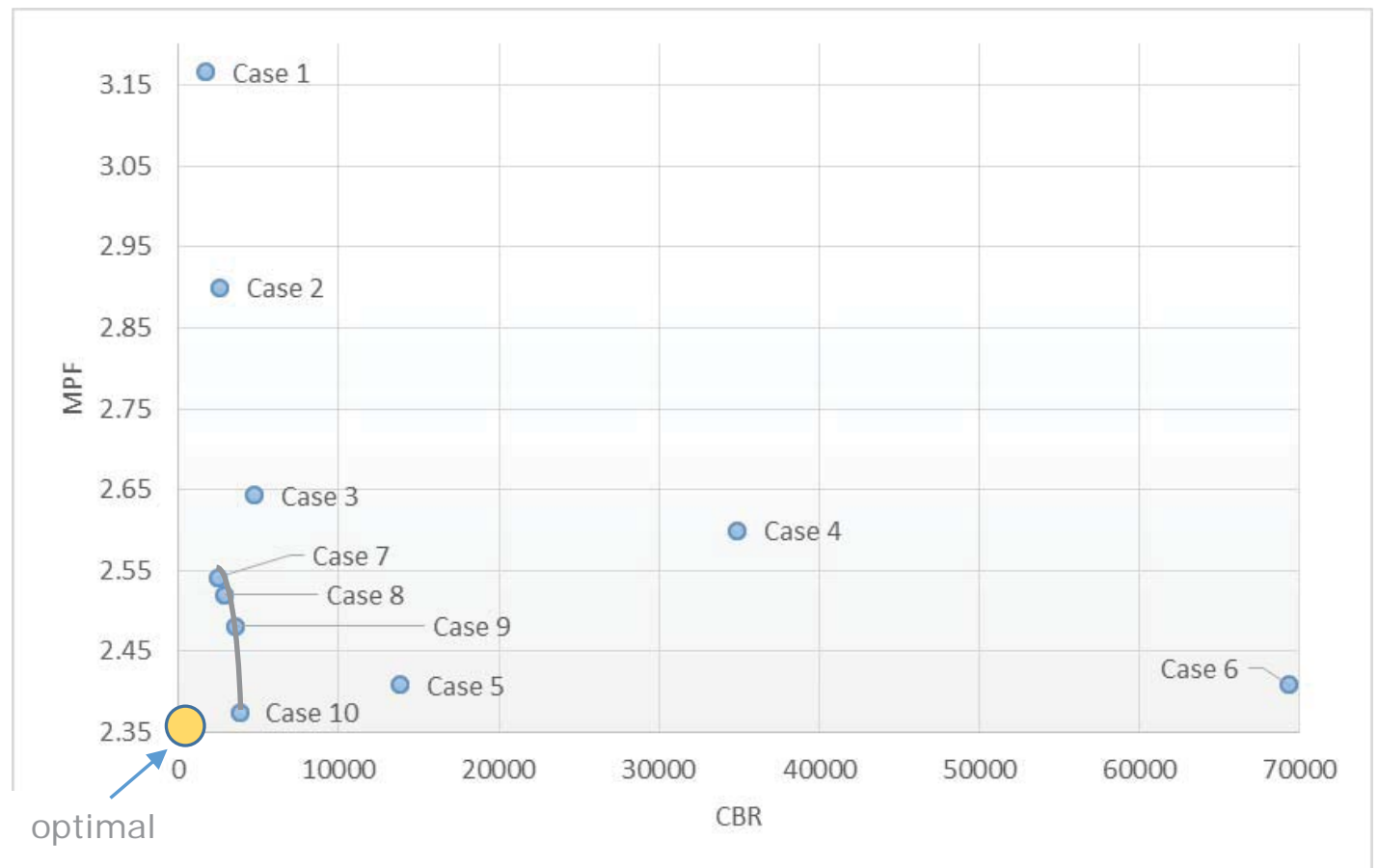

Figure 12.1 Optimization of CBR and MPF Plot

Note: See Figure 12.2 for a plot of the four cases achieving the closest values to the optimal value.

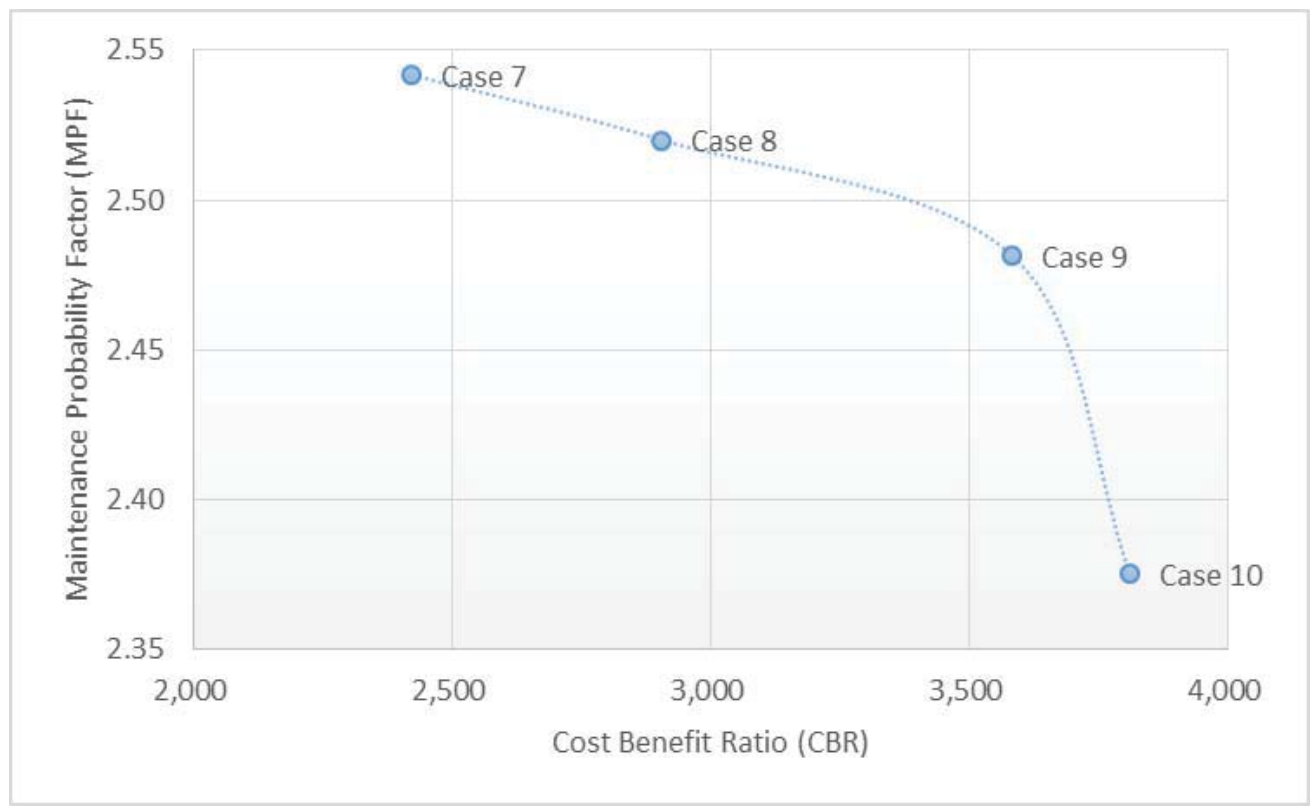

Figure 12.2 Optimization of MPF and CBR for Cases 7,8,9 and 10.

Note: Cases 7,8,9 and 10 represent a Pareto front. 
Based on this plot, it is apparent that when taking both of these variables into consideration, neither will be optimized but rather both need to find a balance where each can occur at an appropriate level to a given situation. Additionally, decision makers can identify which variable is of higher importance - cost to benefit ratio or maintenance - and implement this method as a decision making tool.

When analyzing Figure 12.1 it is apparent that cases 7, 8, 9 and 10 form an optimal trend representative of the Pareto front where these are narrowed down to be the best choices as they achieve an acceptable value for both variables and thus eliminating the other cases as options. It is important to note that with this type of trend, and as defined by the Pareto optima, there must be a trade-off between the two variables where both cannot be optimized simultaneously (Warburton 1987). For instance, Case 10 achieves a better MFP than CBR when compared to the other three cases. This demonstrates the trade-off that occurs when one of the variables, in this case MFP, is optimized over the other. This can be attributed to the fact that all of the subcatchments are being used resulting in a MPF average that is lower in relation to other cases where less subcatchments were used. Given the approximation of Cases 7, 8, 9 and 10 to optimization of both MPF and CBR, with the ideal optimization being the lowest value possible for both, these four cases were analyzed for trends to better understand how optimization may occur. Cases 7, 8 and 9 do not have any LID BMPS implemented in Subcatchments S1, S2, S3 nor S4 which are located at the highest points of the study site. This demonstrates that optimization can occur without the implementation of LID BMPs throughout the entire study site. It also indicates that the most efficient placement of LID BMPs maybe be downstream of the study site where higher runoff rates occur, when compared to runoff rates at the upstream subcatchments. Another noteworthy observation is the use of infiltration trenches was greater in Cases 7, 9 and 10 which contributed to lower costs. It can be said that for 
this specific site of Lámud, infiltration trenches are more efficient since they require less area to manage the same amount of runoff as vegetated swales or retention ponds and thus result in a lower CBR value. The Pareto front can then be used as a decision making tool by stakeholders to identify the most beneficial options based in their circumstances and the trade-off that exist between cases that fill on the Pereto front. Diagrams for the distribution and location of LID BMPs for each case can referenced in Appendix B: LID BMPs Identification Diagram per case.

It is important to note that an investment of this scale is not expected to be done by the farmer or landowner, but rather by the local authorities. Therefore, a total cost of $\$ 938,394.49$ for Case 10 which implements LID BMPs throughout the entire study site and is the most costly of the cases, is still a viable option when compared to an investment of $\$ 2,419,416.00$ Dollars made for the local water distribution system (Municipalidad Provincial de Luya 2011). 


\section{Conclusions}

\subsection{Discussion}

With projects of this magnitude, which present a benefit to the community at large, it is assumed that costs - both initial and maintenance - will be covered by the local government. However, one of the main challenges in implementing new technologies is their initial adoption by stakeholders due to the fact that they are not familiar with the technology nor the benefits it may provide. Additionally, it is also customary, that the community participates in the manual labor of construction and maintenance. Therefore, when and if local authorities are able to fund the initial cost, understanding the likelihood of maintenance by landowners of these systems. If maintenance is unlikely to occur by landowners, funding of the initial costs of these projects would become obsolete and result is a significant financial loss for funding agents.

This is a first attempt at analyzing the three key variables - environmental, economic and social - affecting the long term effectiveness of LID BMPS in the context of a developing community such as Lámud. It is worthy to note that the method to gage the long term maintenance of these system by the categorization of subcatchments as shown in Table 10.2 was observational and would benefit from a more thorough process of identifying characteristics and variables to better understand the likelihood of maintenance of LID BMPs by private landowners.

In the case that LID BMPs were to be adopted and implemented by individuals, it can be argued that those with more disposable income would be more like to adopt and maintain these systems. However, in the context of this community, a higher percentage of those who earn higher incomes are not permanent residents of the city and thus would not benefit directly. It is then more likely for the farmer, whose 
investment in his crops and earnings are at stake who would be more like to adopt and maintain the LID BMPs.

Additionally, the area required for each of these LID BMPs within each subcatchment may be of concern as land is highly valued, especially for a farmer. However, it is believed that the benefits obtained from implementing LID BMPs would balance the loss of the area used given that both infiltration trenches and vegetated swales would require minimal areas with minimal encroachment to prime real estate.

In the cases of institutional subcatchment, which are densely developed with high percentage of impervious surface, there would be additional cost related with the retrofitting of present construction in order to implement LID BMPs. This may, in such cases, become a limiting factor in the adoption of these systems within institutional subcatchments

\subsection{Recommendations}

The challenges become greater when technologies that are introduced are not appropriate resulting in secondary effects which then need to be corrected. Environmental, economic and maintenance probability is more likely to occur when appropriate technologies are identified and adapted to fit the community's needs and skills.

In the case of Lámud, where conventional stormwater management infrastructure is starting to be incorporated into urban development plans, it would be recommended that LID BMPs are taken into consideration as they would result in environmental, capital and maintenance cost savings. LID BMPs are also more appropriate technologies for a rural setting given their potential to handle and treat runoff from agricultural lands, which dominate the site, in a cost effective manner. 
Based on the results, Case 7 - seen in Figure 13.1 below - would be recommend for implementation in Lámud as it is one of the four optimal cases based on the Pareto front. One of the criteria used in suggesting Case 7 over the other three - Cases 8, 9, and 10 - is that, in the setting of Lámud, the value of CBR is considered to be a higher priority, as costs will ultimately dictate the adoption of any new technology by stakeholders. This is attributed to the fact that when adopting new technologies, the understanding of it's benefits are not known nor apparent through experience. Therefore, a low cost would be a valuable incentive at the introduction phase of these systems. 


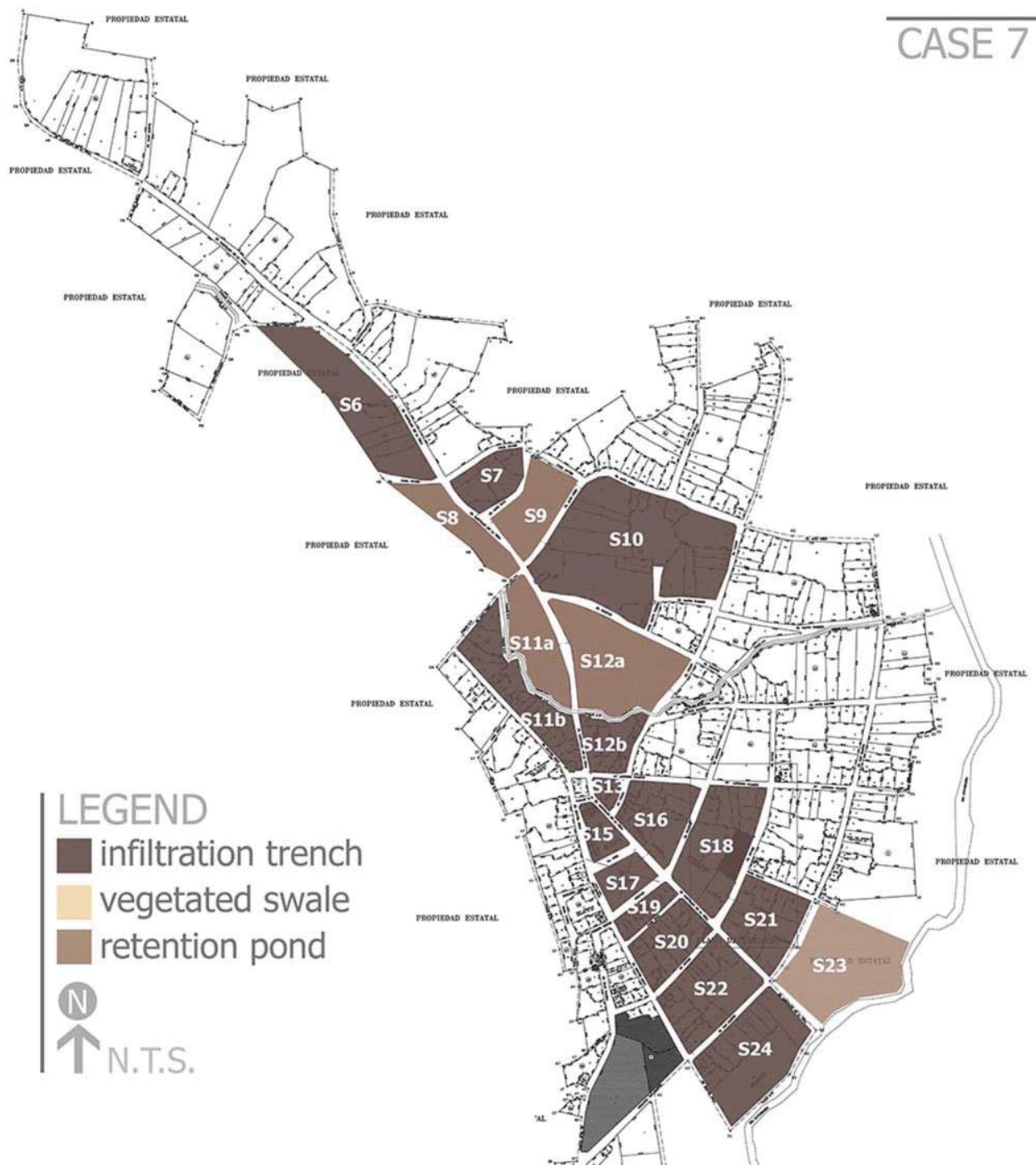

Figure 13.1 Case 7. Recommended Case.

It is also recommended that with the implementation of vegetated swales and retention ponds boundary protection, such as fencing or barbwire, is considered as these may attract livestock which may deteriorate the systems and decrease their lifespans as well as present a danger for children and others that may not be aware of the LID BMP location. 


\subsection{Future Work}

Given the capabilities of SWMM 5.1 to perform model simulation of water quality it would be of value to analyze these parameters in a setting with high percentages of agricultural lands as they are large contributors of solids contaminants from fertilizers.

Based in this study and the elementary method implemented to develop a MPF, it would be of great value to further develop methods to measure the feasibility of the adoption and maintenance of these systems by land owners and local authorities. A deep understanding of how these types of technologies can be transfered to other cultures would allow precision in the decision making process when implementing and recommending new technologies. 


\section{References}

Amec Earth \& Environmental, Inc. . 2008. "Knox County, Tennessee: Stormwater Management Manual - Volume 2 Technical Guidance." Chap. 4, 91-108. Knoxville, TN.

Ashley, R., S. Garvin, E. Pasche, A. Vassilopoulos, and C. Zevenbergen. 2007. Advances in Urban Flood Management. Londo, UK.

Barkdoll, Brian D., and David W. Watkins. 2009. Stormwater Management: Conventional and Low Impact Methods. Linus Publications.

BBC News. 2006. Profile: Alan Garcia. June 06. Accessed April 25, 2015. http://news.bbc.co.uk/2/hi/5047896.stm.

BBC News. 2011. Profile: Alberto Fujimori.December 8. Accessed April 25, 2015. http://www. bbc.com/news/ world-latin-america-16097439.

Brouwer, Roy, Sonia Akter, Luke Brander, and Enamul Haque. 2007. "Socioeconomic Vulnerability and Adaptation to Environmental Risk: A Case Study of Climate Change and Flooding in Bangladesh. ." Risk Analysis 313-326.

Bustamante Oblitas, Carlos A. 2012. "Diagnóstico Ambiental Local de la Provincia de Luya - Lámud." Lamud.

Cano, Olga M. 2012. "Figure 5.1 Visit to Water Intake." Digital Image - Personal Collection. Fair Use. 
Crosby, Alfred W. 1967. "Conquistador y Pestilencia: The First New World Pandemic and the Fall of the Great Indian Empires." The Hispanic American Historical Review 47 (3): 321-337.

Dasgupta, P., J.F. Morton, D. Dodman, B. Karapinar, F. Meza, M.G. Rivera-Ferre, A. Toure Sarr, and K.E. Vincent. 2014. Rural areas. In: Climate Change 2014: Impacts, Adaptation, and Vulnerability. Part A: Global and Sectoral Aspects. Contribution of Working Group II to the Fifth Assessment Report of the Intergovernmental Panel on Climate Change. United Kingdom and New: Cambridge University Press, 613-657.

Department of Environmental Protection, Bureau of Watershed. 2006. "Pennsylvania Stormwater Best Management Practices Manual." December.

EIU ViewsWire. 2003. "Peru politics: Toledo faces test of authority."

EPA. 1999. "Storm Water Technology Fact Sheet Infiltration Trench." Washington DC.

EPA. 1999. "Storm Water Technology Fact Sheet: Vegetated Swales." Office of Water, Washington DC.

EPA. 2015. SWMM. January 27. Accessed April 6, 2015. http://www2.epa.gov/waterresearch/storm-water-management-model-swmm\#downloads.

Fryd, O., A. Backhaus, J. Jeppesen, S.T. Ingvertsen, H. Birch, M. Bergman, T.E.P. Petersen, C. Fratini, and M.B. Jensen. 2009. Connected Disconnections: Conditions for Landscape-Based Disconnections of Stormwater from the Copenhagen Sewer System in the Catchment Area for River Harrestrup. The 2BG Project Working Report: River Harrestrup Case Study. Copenhagen, 
Denmark: Danish Centre for Forest, Landscape \& Planning, University of Copenhagen.

Goldenfum, Joel A., Rutinéia Tassi, Adalberto Meller, Daniel G. Allasia, and André L. da Silveira. 2007. Challenges for the Sustainable Urban Stormwater Management in Developing Countries: From basic education to technical and institutional issues. Novatech.

Hellström, D., U. Jeppsson, and E. Kärrman. 2000. " A framework for systems analysis of sustainable urban water management." Environmental Impact Assesment Review 311-321.

Hennelly, B. 2005. SuDS-Principles and Drivers. Dublin, Ireland. : Dublin City Council.

Holman-Dodds J.K., A. Allen Bradley, and Kenneth W. Potter. 2003. "EVALUATION OF HYDROLOGIC BENEFITS OF INFILTRATION." JOURNAL OF THE AMERICAN WATER RESOURCES ASSOCIATION 205-215.

Huarino Ch., Mercedes. 2009. "Plan Integral de Gestión Ambiental de Residuos Sólidos PIGARS - Luya." Lamud.

Ministerio de Vivienda, Construcción y Saneamiento - Municipalidad de la Provincial de Luya. 2011. "Ampliacion y Mejoramineto del Sistema de Agua Potable del Sistema de Alcantarillado de la Localidad de Lamud y Anexos, Provincia de Luya - Amazonas." Lamud - peru, December.

Municipalidad Provincial de Luya. 2011. "Expediente Tecnico: Ampliacion y mejoramiento del sistem de sgua y slcantarillado de la localidad de Lamud y anexos, Provincia de Luya-Amazonas ." Lamud, Amazonas, Peru. 
Nnadi, Fidelia N. (Ola). 2008. "Best Management Practices (BMPs) for Surface Water Pollution in Developing Countries." World Environmental and Water Resources Congress.

NOAA. 2015. National Oceanic and Atmospheirc Administration. Fair Use. Accessed 2015. http://www.noaa.gov/.

Peace Corps. 2007. Information Booklet - Peru. Washington, DC. : United States Government.

Regional Government of Amazonas. 2012. "Figure 10.1 Map of Province of Luya with boundaries and location of districts." Fair Use.

Rossman, Lewis A. 2010. Storm water management model user's manual - Version 5.0. Cincinnati.

Roy, A.H., S.J. Wenger, T.D. Fletcher, C.J. Walsh, A.R. Ladson, W.D. Shuster, H.W. Thurston, and R.R. Brown. 2008. "Impediments and solutions to sustainable, watershed-scale urban stormwater management: Lessons from Australia and the United States." Environmental Management 344-359.

Toohey, Ian P. 2012. "Figure 4.1 Author during a water system inspection." Digital Image - Personal Collection. Fair Use.

United States Department of Agriculture. 2007. "Chapter 7: Hydrologic Soil Groups." In National Engineering Handbook.

UT. 2015. Political Map of Peru. Fair Use. Accessed April 23, 2015. http://www.lib.utexas.edu/maps/americas/peru_rel_06.jpg.

Vand I Byer. 2015. Project Water in Cities. April 02. http://www.vandibyer.dk/. 
Warburton, Arthur. 1987. "Approximation of Pareto Optima in Multiple-Objective, Shortest-Path Problems." Operations Research 70-79.

WERF. 2009. User's Guide to the BMP and LID Whole Life Cost Models Version 2.0. Alexandria.

Wilderer, P.A. 2004. "Applying sustainable water management concepts in rural and urban areas: Some thoughts about reasons, means and needs. ." Water Science Technology 8-16.

Wondimu, Dr. Abeje, and Dr. Elham Alfakhi. 2001. Approach for sustainable urban storm water management in the context of developing countries. Novatech.

Wong, T., and R. Brown. 2009. "The water sensitive city: Principles for practice." Water Science Technology 673-682.

Wurbs, Ralph A., and Wesley P. James. 2001. Water Resources Engineering. Prentice Hall.

Zhou, Qianqian. 2014. "A Review of Sustainable Urban Drainage Systems Considering the Climate Change and Urbanization Impacts." Water 976-992. 


\section{Appendices}

\subsection{Appendix A: Chachapoyas Rainfall Data}

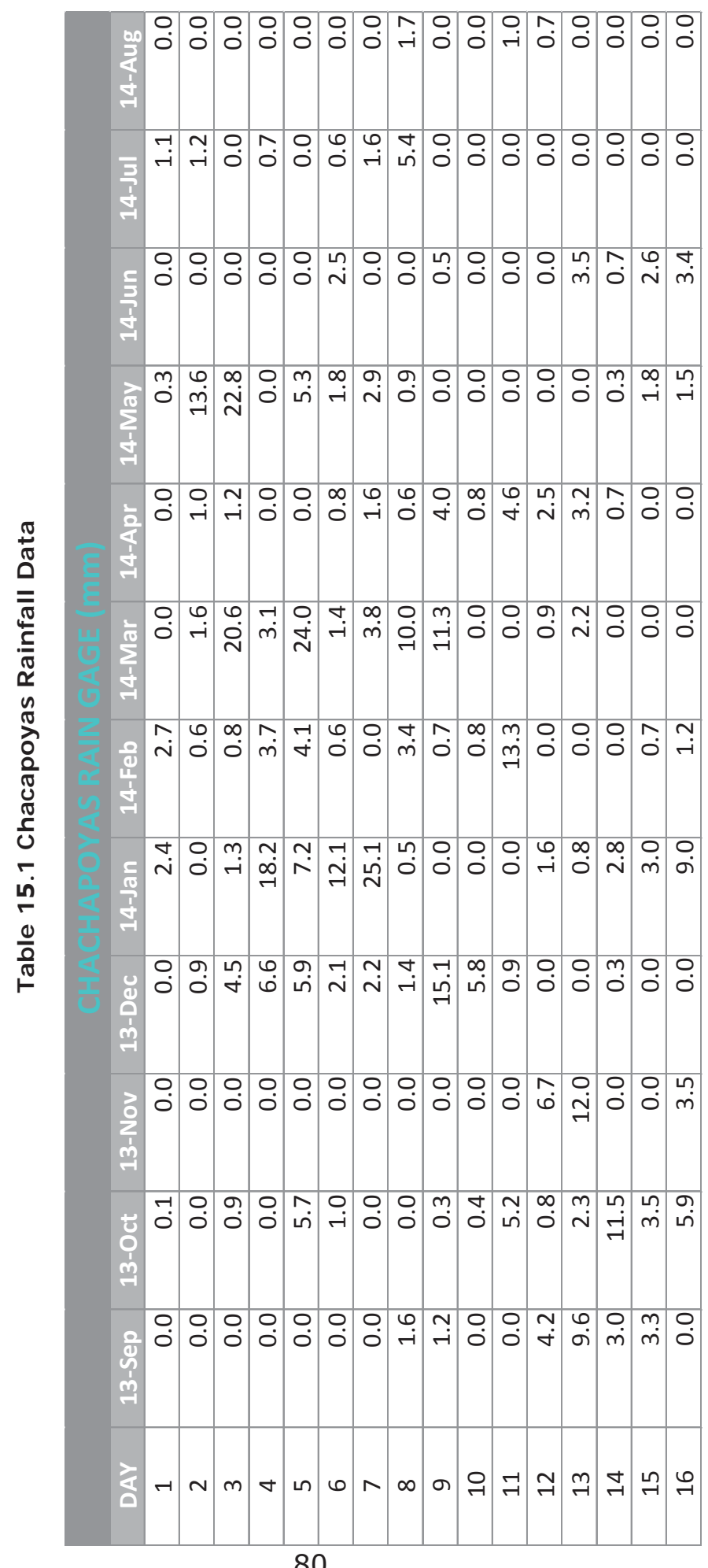




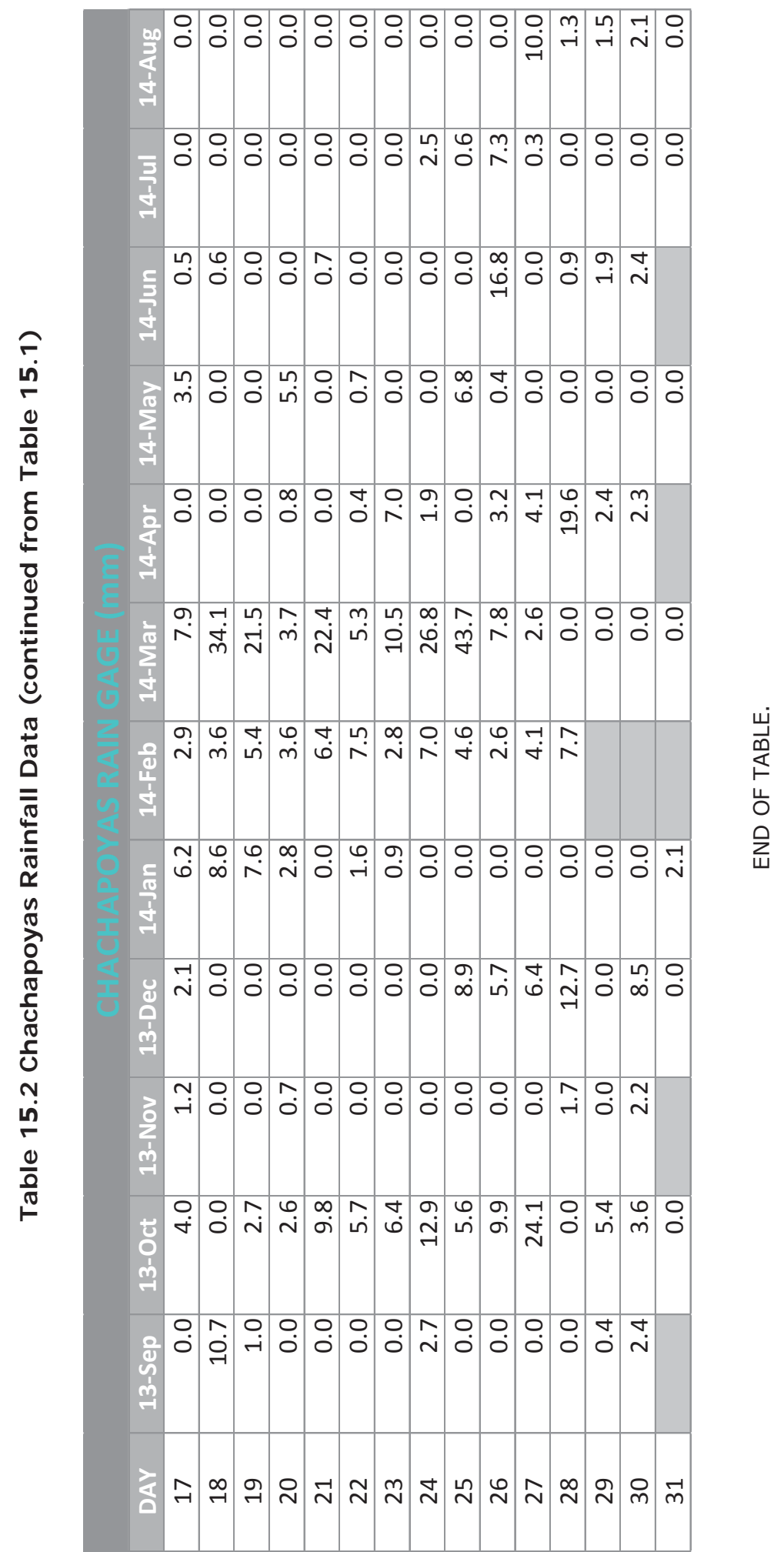




\subsection{Appendix B: LID BMPs Identification Diagram per case}

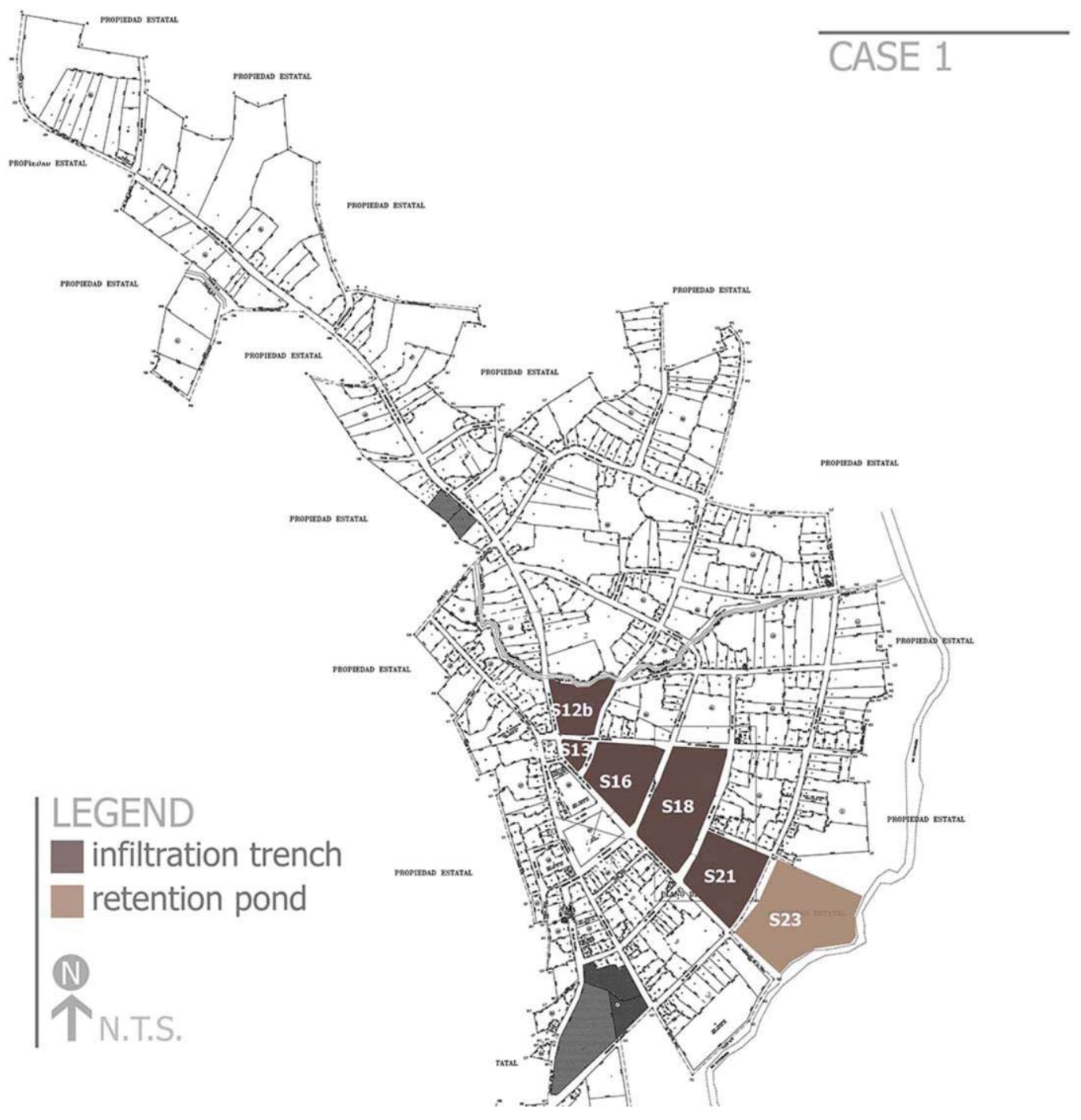

Figure 15.1 Case 1 LID BMP Identification Diagram

Note: Diagram of site plan is meant for reference only. Not to scale. 


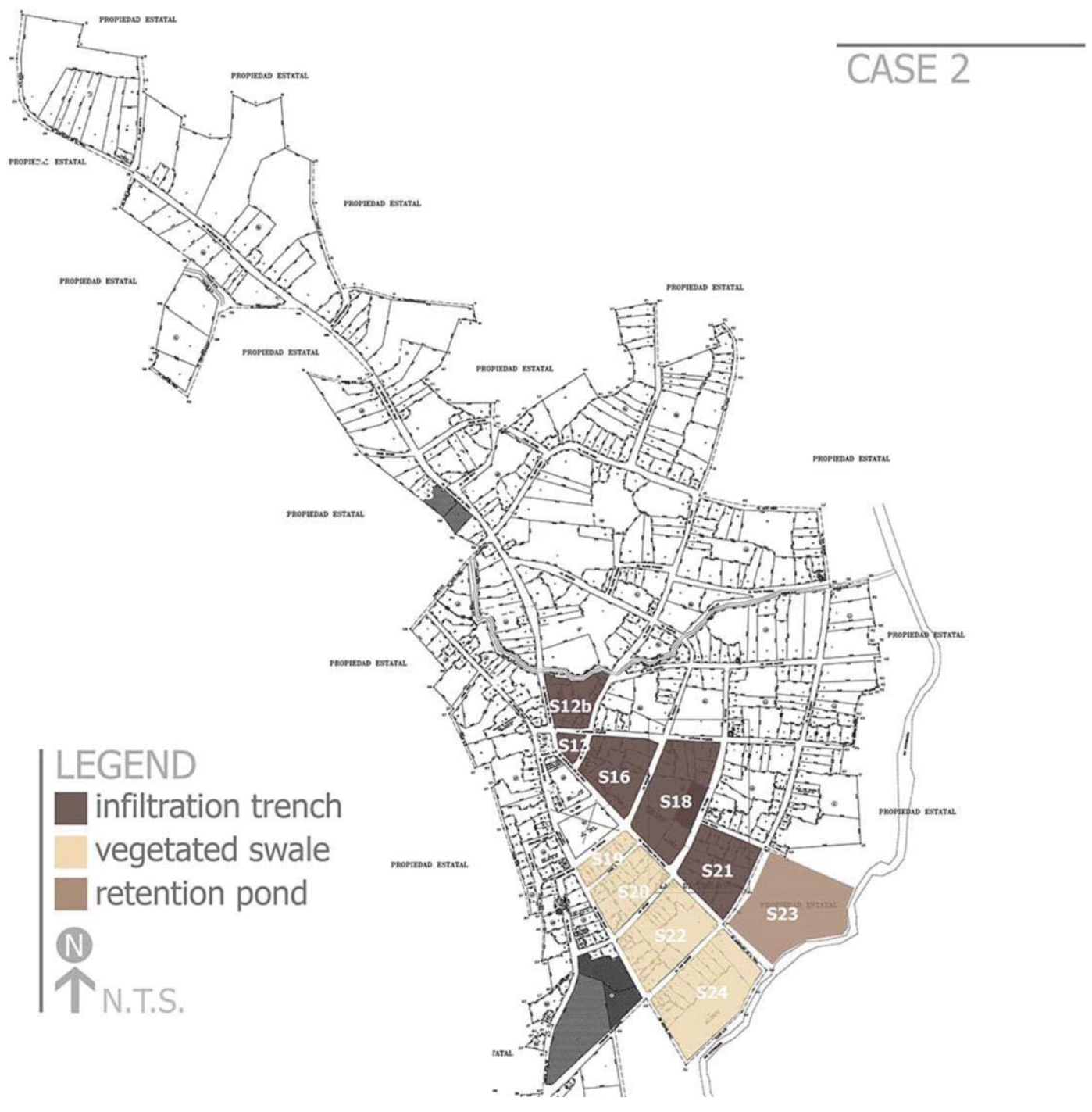

Figure 15.2 Case 2 LID BMP Identification Diagram

Note: Diagram of site plan is meant for reference only. Not to scale. 


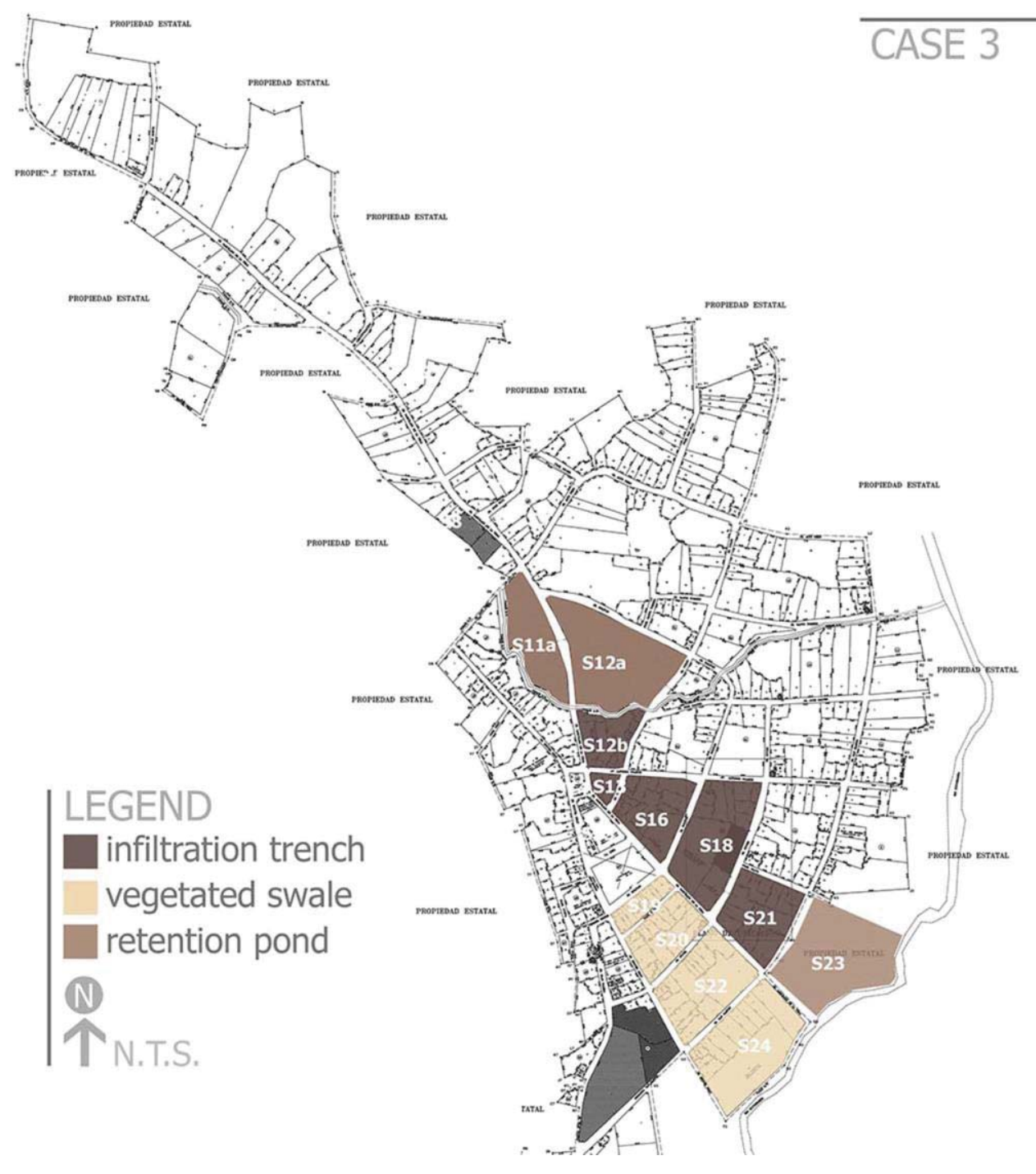

Figure 15.3 Case 3 LID BMP Identification Diagram

Note: Diagram of site plan is meant for reference only. Not to scale. 


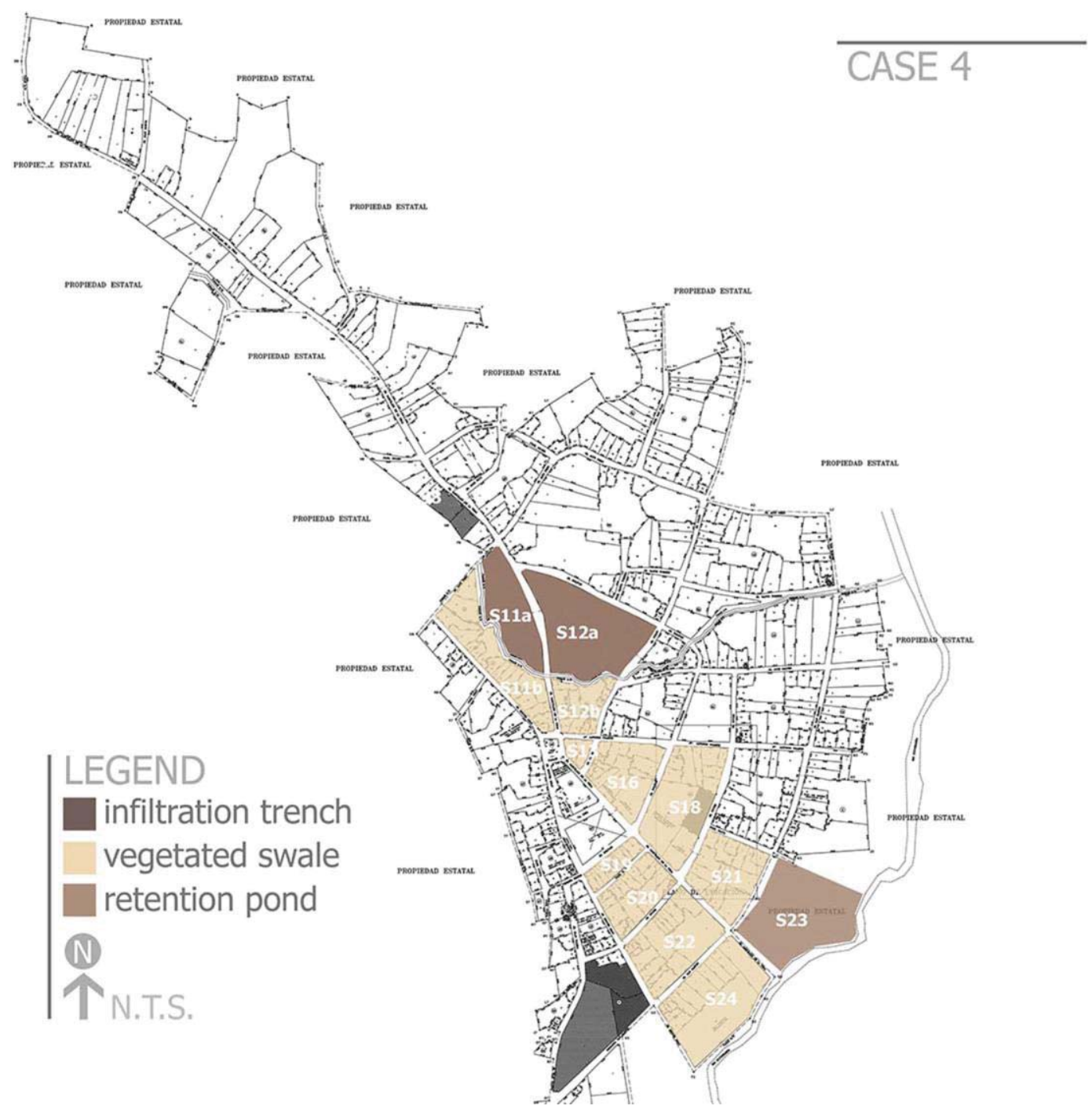

Figure 15.4 Case 4 LID BMP Identification Diagram

Note: Diagram of site plan is meant for reference only. Not to scale. 


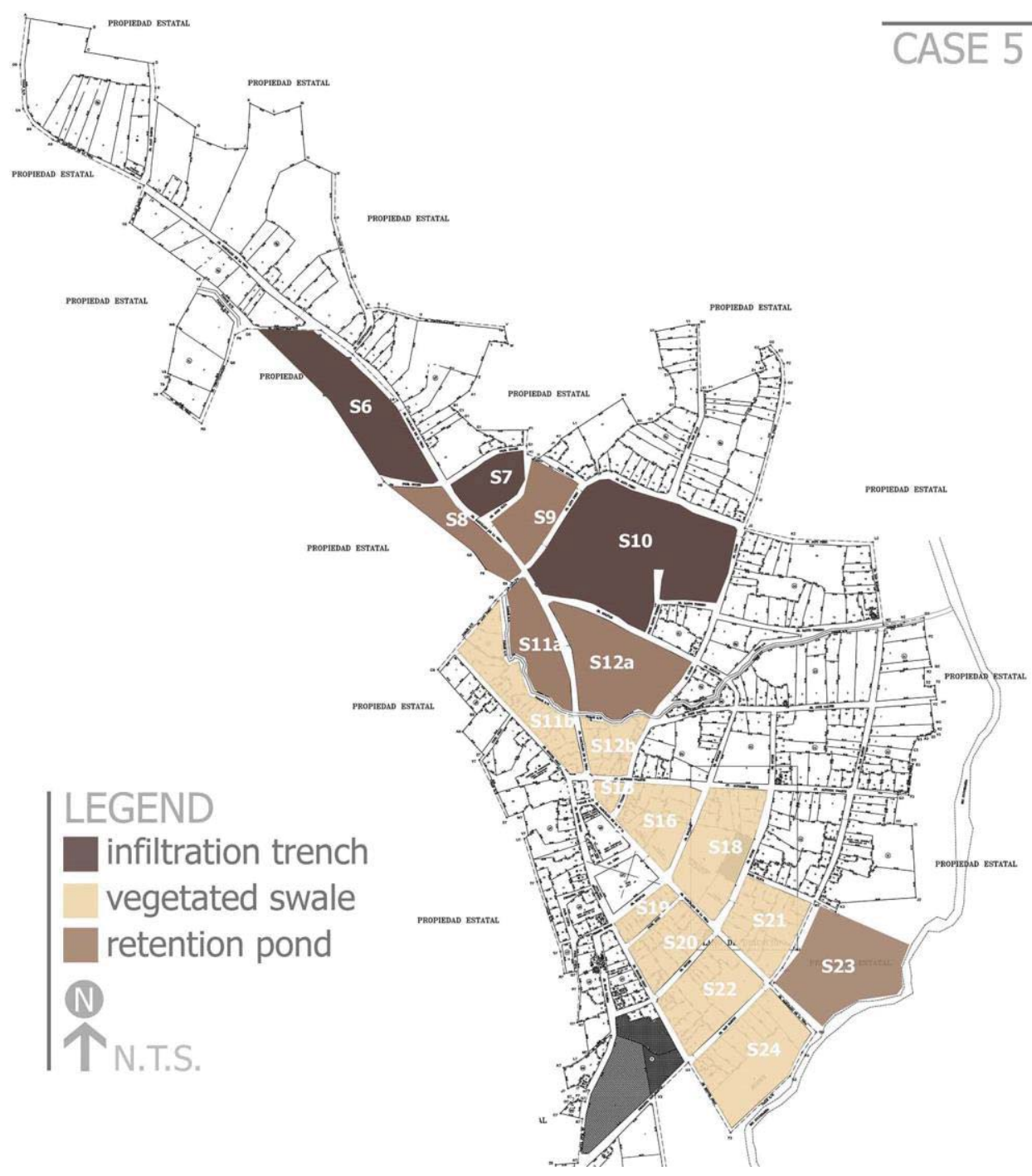

Figure 15.5 Case 5 LID BMP Identification Diagram

Note: Diagram of site plan is meant for reference only. Not to scale. 


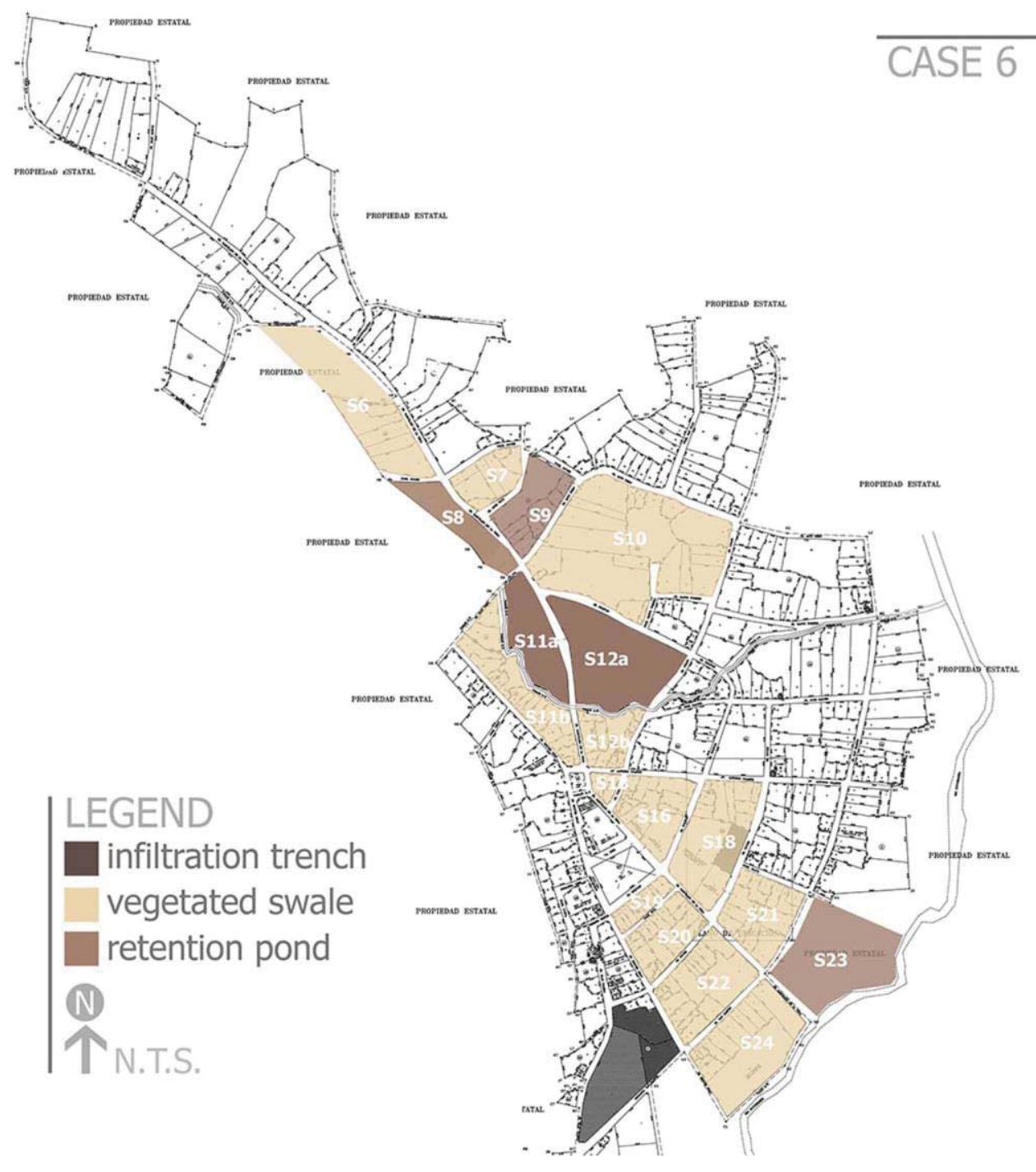

Figure 15.6 Case 6 LID BMP Identification Diagram

Note: Diagram of site plan is meant for reference only. Not to scale. 


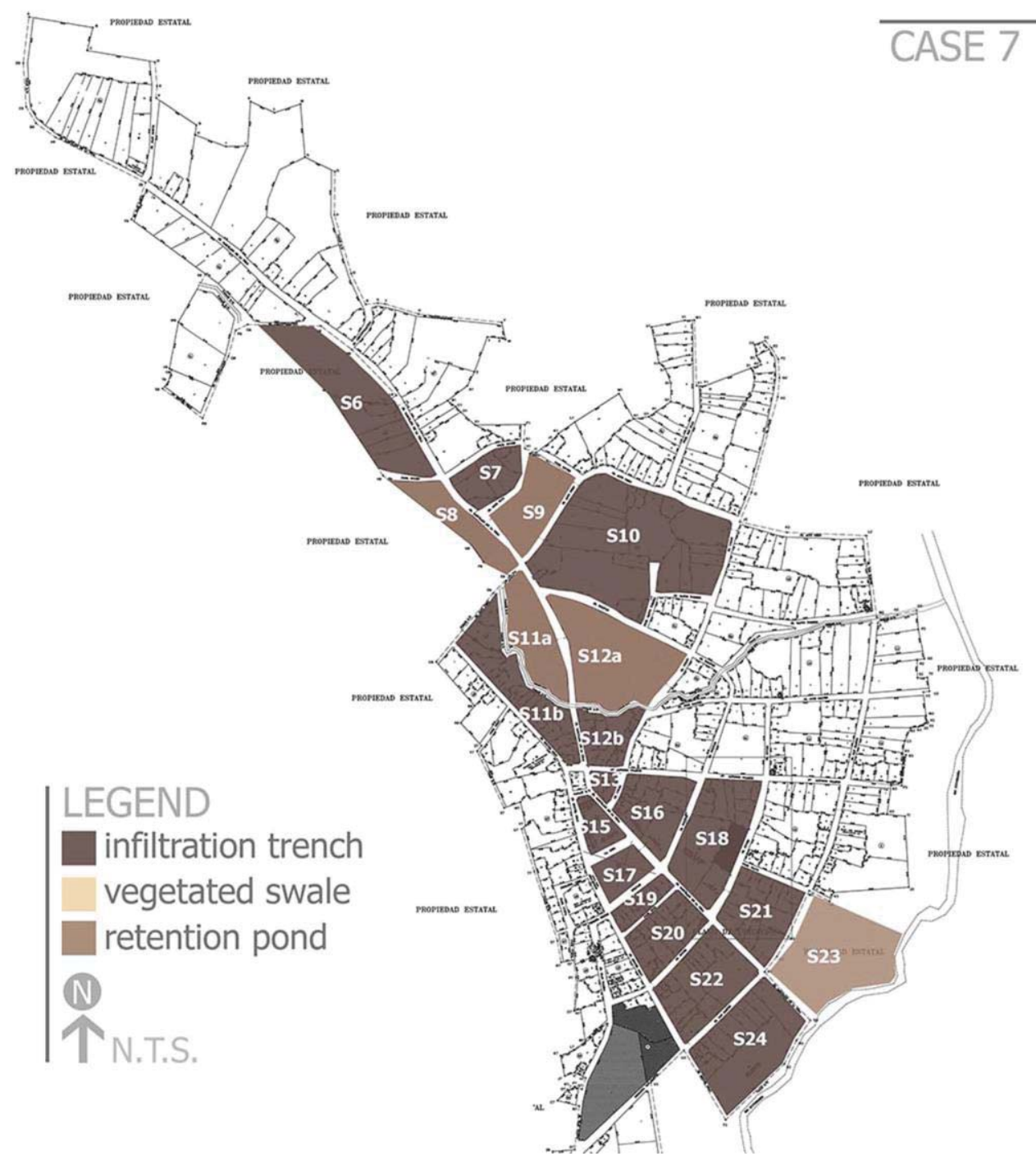

Figure 15.7 Case 7 LID BMP Identification Diagram

Note: Diagram of site plan is meant for reference only. Not to scale. 


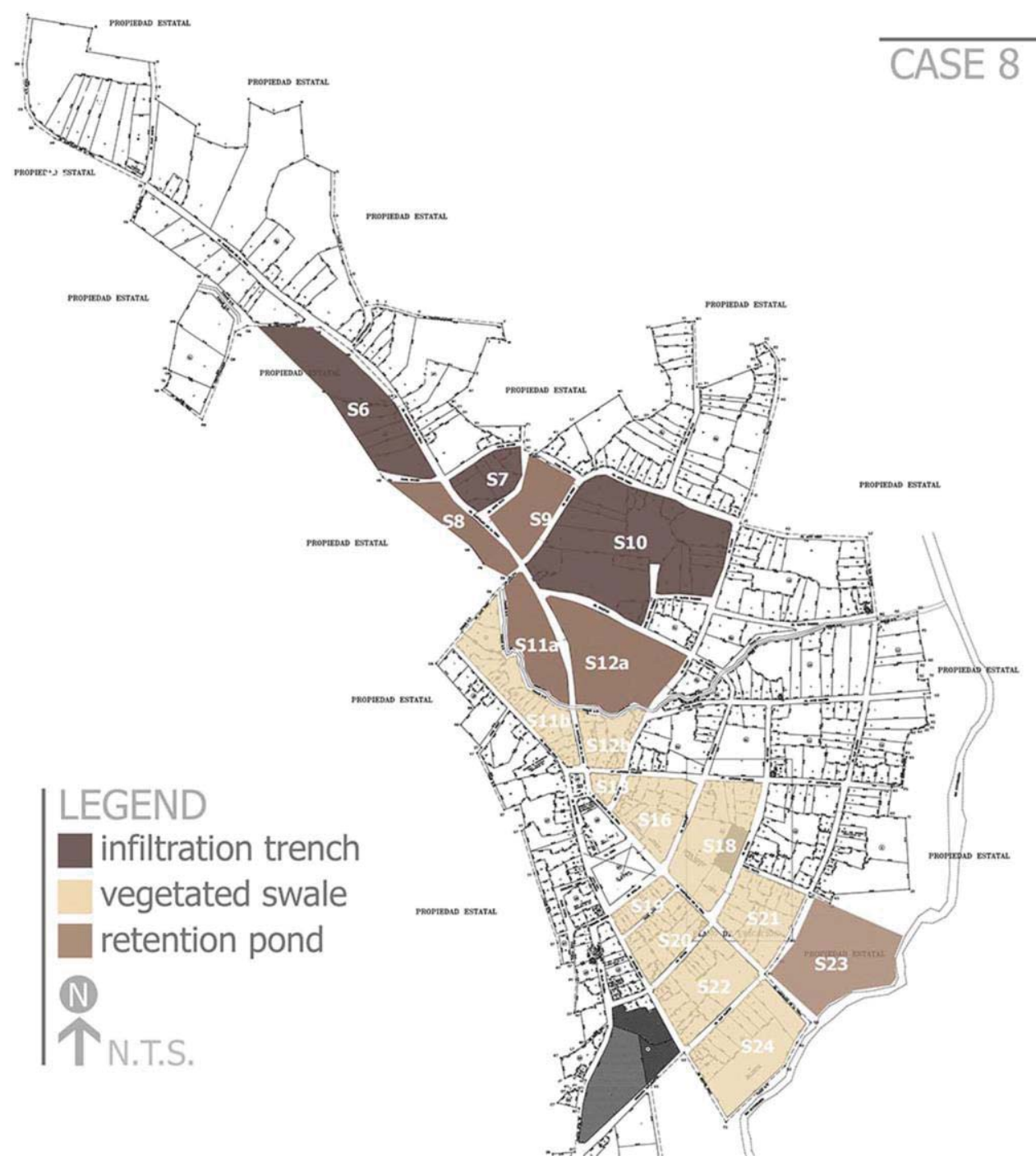

Figure 15.8 Case 8 LID BMP Identification Diagram

Note: Diagram of site plan is meant for reference only. Not to scale. 


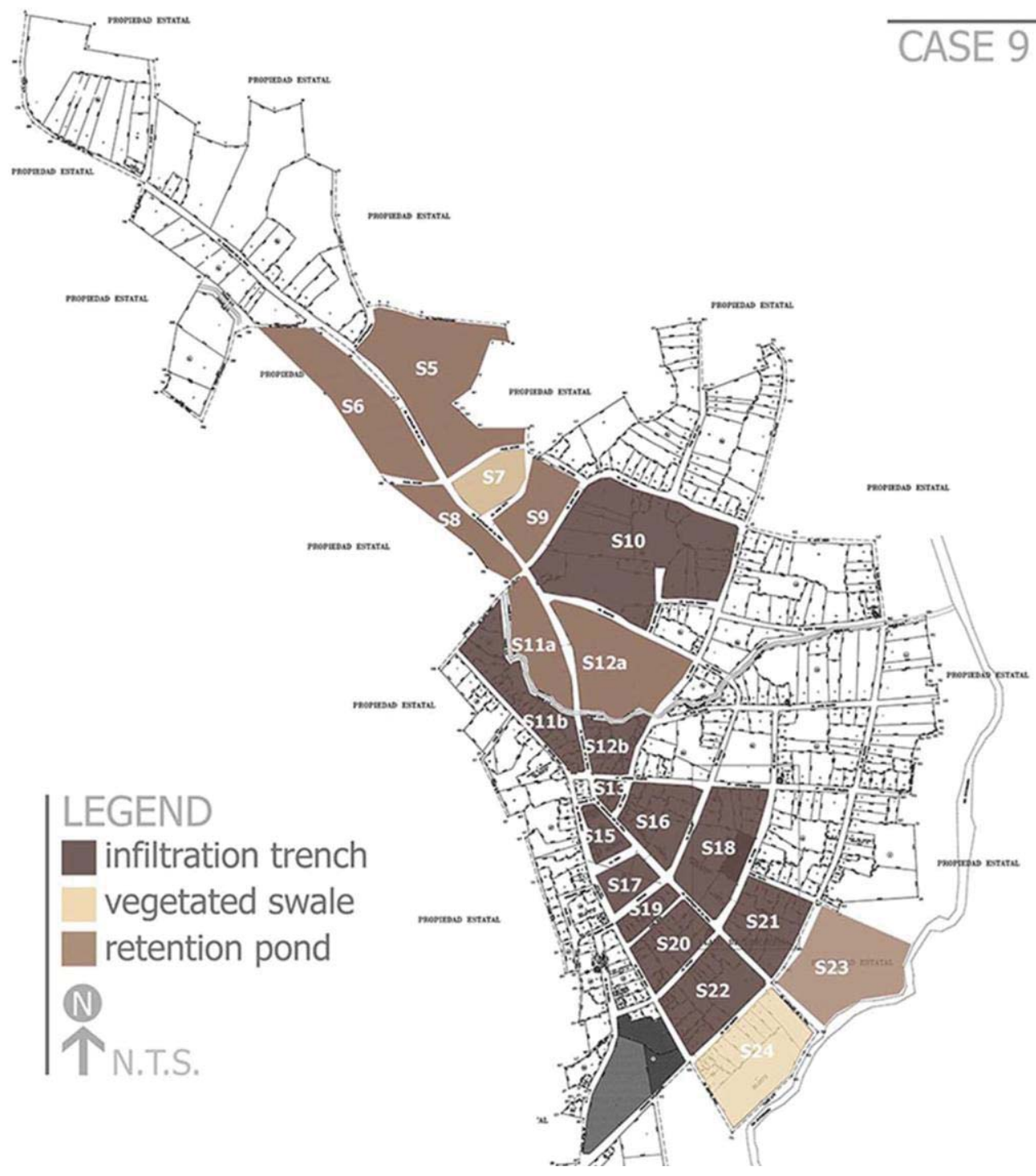

Figure 15.9 Case 9 LID BMP Identification Diagram

Note: Diagram of site plan is meant for reference only. Not to scale. 


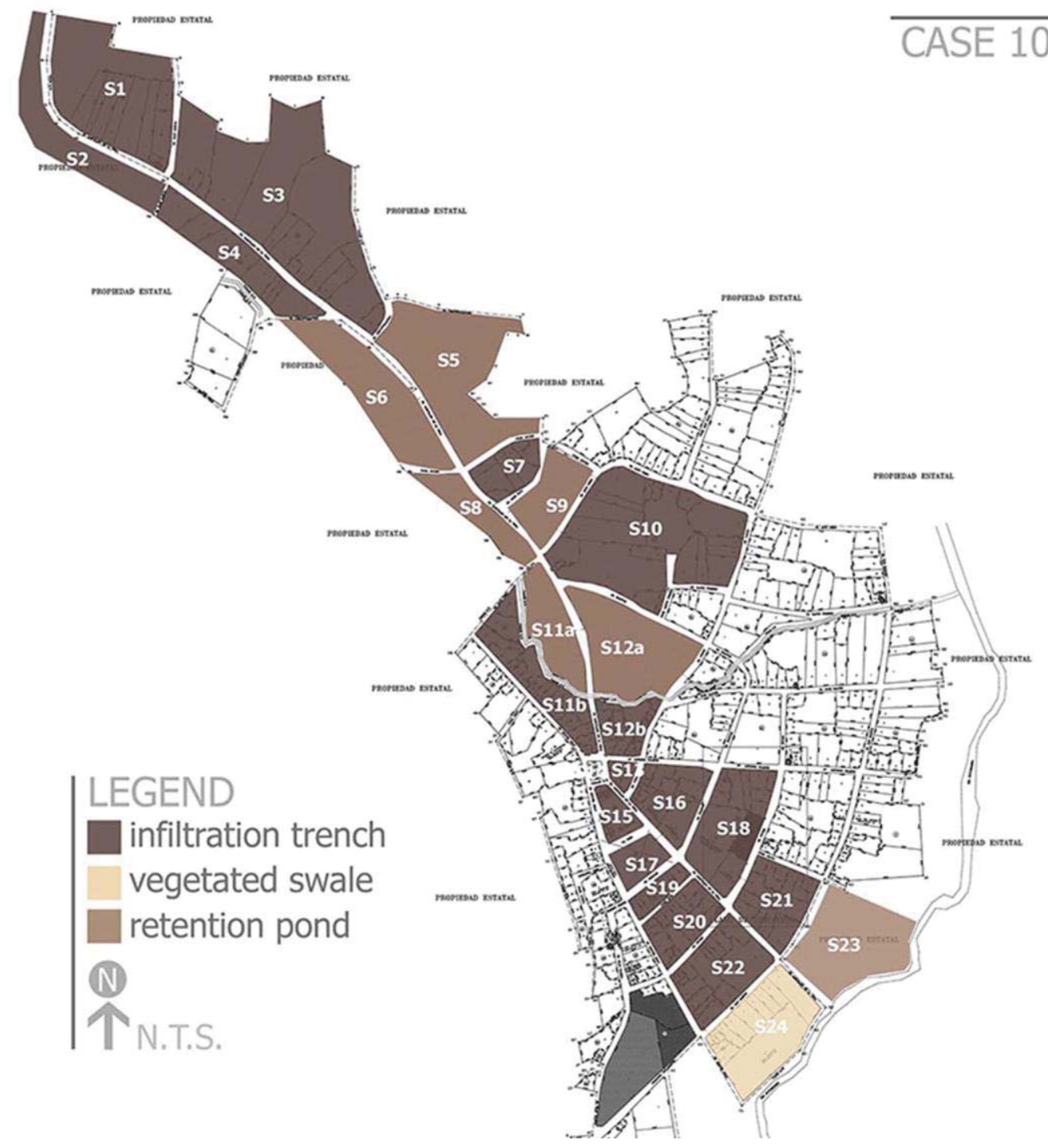

Figure 15.10 Case 10 LID BMP Identification Diagram

Note: Diagram of site plan is meant for reference only. Not to scale. 


\subsection{Appendix C: LID BMPs Areas per Case}

Table 15.3 Case 1 LID BMP Areas

\begin{tabular}{|l|l|r|}
\hline SUBCATCHMENT & \multicolumn{1}{|c|}{ LID BMPS } & \multicolumn{1}{c|}{$\begin{array}{c}\text { AREA } \\
(\mathrm{m} 2)\end{array}$} \\
\hline S12b & Infiltration Trench & 351.76 \\
\hline S13 & Infiltration Trench & 85.55 \\
\hline S16 & Infiltration Trench & 575.55 \\
\hline S18 & Infiltration Trench & 923.59 \\
\hline S21 & Infiltration Trench & 646.03 \\
\hline S23 & Retention Pond & 525.00 \\
\hline
\end{tabular}

Table 15.4 Case 2 LID BMP Areas

\begin{tabular}{|l|l|r|}
\hline SUBCATCHMENT & \multicolumn{1}{|c|}{ LID BMPs } & \multicolumn{1}{|c|}{$\begin{array}{c}\text { AREA } \\
(\mathrm{m} 2)\end{array}$} \\
\hline S12b & Infiltration Trench & 351.76 \\
\hline S13 & Infiltration Trench & 85.55 \\
\hline S16 & Infiltration Trench & 575.55 \\
\hline S18 & Infiltration Trench & 923.59 \\
\hline S19 & Vegetative Swale & 300.75 \\
\hline S20 & Vegetative Swale & 434.85 \\
\hline S21 & Infiltration Trench & 646.03 \\
\hline S22 & Vegetative Swale & 549.45 \\
\hline S23 & Retention Pond & 525.00 \\
\hline S24 & Vegetative Swale & 625.88 \\
\hline
\end{tabular}


Table 15.5 Case 3 LID BMP Areas

\begin{tabular}{|l|l|r|} 
& \multicolumn{1}{c|}{ LID BMPs } & \multicolumn{1}{c|}{$\begin{array}{c}\text { AREA } \\
\text { SUBCATCHMENT }\end{array}$} \\
\hline S11a & Retention Pond & 420.59 \\
\hline S11a & Infiltration Trench & 560.79 \\
\hline S12a & Retention Pond & 853.17 \\
\hline S12a & Infiltration Trench & 1137.56 \\
\hline S12b & Infiltration Trench & 351.76 \\
\hline S13 & Infiltration Trench & 85.55 \\
\hline S16 & Infiltration Trench & 575.55 \\
\hline S18 & Infiltration Trench & 923.59 \\
\hline S19 & Vegetative Swale & 300.75 \\
\hline S20 & Vegetative Swale & 434.85 \\
\hline S21 & Infiltration Trench & 646.03 \\
\hline S22 & Vegetative Swale & 549.45 \\
\hline S23 & Retention Pond & 525.00 \\
\hline S24 & Vegetative Swale & 625.88 \\
\hline
\end{tabular}

Table 15.6 Case 4 LID BMP Areas

\begin{tabular}{|l|l|r|}
\hline SUBCATCHMENT & \multicolumn{1}{|c|}{ LID BMPs } & \multicolumn{1}{c|}{$\begin{array}{c}\text { AREA } \\
(\mathrm{m} 2)\end{array}$} \\
\hline S11a & Retention Pond & 420.59 \\
\hline S11a & Infiltration Trench & 560.79 \\
\hline S11b & Vegetative Swale & 754.28 \\
\hline S12a & Retention Pond & 853.17 \\
\hline S12a & Infiltration Trench & 1137.56 \\
\hline S12b & Vegetative Swale & 379.58 \\
\hline S13 & Vegetative Swale & 178.13 \\
\hline S16 & Vegetative Swale & 463.73 \\
\hline S18 & Vegetative Swale & 606.30 \\
\hline S19 & Vegetative Swale & 300.75 \\
\hline S20 & Vegetative Swale & 434.85 \\
\hline S21 & Vegetative Swale & 482.48 \\
\hline S22 & Vegetative Swale & 549.45 \\
\hline S23 & Retention Pond & 525.00 \\
\hline S24 & Vegetative Swale & 625.88 \\
\hline
\end{tabular}


Table 15.7 Case 5 LID BMP Areas

\begin{tabular}{|l|l|r|}
\hline SUBCATCHMENT & \multicolumn{1}{c|}{ LID BMPS } & \multicolumn{1}{l|}{$\begin{array}{c}\text { AREA } \\
\text { (m2) }\end{array}$} \\
\hline S6 & Infiltration Trench & 1083.80 \\
\hline S7 & Infiltration Trench & 375.18 \\
\hline S8 & Retention Pond & 320.00 \\
\hline S8 & Infiltration Trench & 426.67 \\
\hline S9 & Retention Pond & 393.83 \\
\hline S9 & Infiltration Trench & 525.10 \\
\hline S10 & Infiltration Trench & 2414.56 \\
\hline S11a & Retention Pond & 420.59 \\
\hline S11a & Infiltration Trench & 560.79 \\
\hline S11b & Vegetative Swale & 754.28 \\
\hline S12a & Retention Pond & 853.17 \\
\hline S12a & Infiltration Trench & 1137.56 \\
\hline S12b & Vegetative Swale & 379.58 \\
\hline S13 & Vegetative Swale & 178.13 \\
\hline S16 & Vegetative Swale & 463.73 \\
\hline S18 & Vegetative Swale & 606.30 \\
\hline S19 & Vegetative Swale & 300.75 \\
\hline S20 & Vegetative Swale & 434.85 \\
\hline S21 & Vegetative Swale & 482.48 \\
\hline S22 & Vegetative Swale & 549.45 \\
\hline S23 & Retention Pond & 525.00 \\
\hline S24 & Vegetative Swale & 625.88 \\
\hline
\end{tabular}


Table 15.8 Case 6 LID BMP Areas

\begin{tabular}{|c|c|c|}
\hline SUBCATCHMENT & LID BMPs & $\begin{array}{l}\text { AREA } \\
(\mathrm{m} 2)\end{array}$ \\
\hline S6 & Vegetative Swale & 820.80 \\
\hline S7 & Vegetative Swale & 387.30 \\
\hline S8 & Retention Pond & 320.00 \\
\hline S8 & Vegetative Swale & 576.53 \\
\hline S9 & Retention Pond & 393.83 \\
\hline S9 & Vegetative Swale & 477.08 \\
\hline S10 & Vegetative Swale & 1086.68 \\
\hline S11a & Retention Pond & 420.59 \\
\hline S11a & Infiltration Trench & 560.79 \\
\hline S11b & Vegetative Swale & 754.28 \\
\hline $\mathrm{S} 12 \mathrm{a}$ & Retention Pond & 853.17 \\
\hline S12a & Infiltration Trench & 1137.56 \\
\hline S12b & Vegetative Swale & 379.58 \\
\hline S13 & Vegetative Swale & 178.13 \\
\hline S16 & Vegetative Swale & 463.73 \\
\hline S18 & Vegetative Swale & 606.30 \\
\hline S19 & Vegetative Swale & 300.75 \\
\hline S20 & Vegetative Swale & 434.85 \\
\hline S21 & Vegetative Swale & 482.48 \\
\hline S22 & Vegetative Swale & 549.45 \\
\hline S23 & Retention Pond & 525.00 \\
\hline S24 & Vegetative Swale & 625.88 \\
\hline
\end{tabular}


Table 15.9 Case 7 LID BMP Areas

\begin{tabular}{|l|l|r|} 
& & \\
SUBCATCHMENT & \multicolumn{1}{|c|}{ LID BMPS } \\
\hline S6 & Infiltration Trench & 1083.80 \\
\hline S7 & Infiltration Trench & 375.18 \\
\hline S8 & Retention Pond & 320.00 \\
\hline S8 & Infiltration Trench & 426.67 \\
\hline S9 & Retention Pond & 393.83 \\
\hline S9 & Infiltration Trench & 525.10 \\
\hline S10 & Infiltration Trench & 2414.56 \\
\hline S11a & Retention Pond & 420.59 \\
\hline S11a & Infiltration Trench & 560.79 \\
\hline S11b & Infiltration Trench & 715.15 \\
\hline S12a & Retention Pond & 853.17 \\
\hline S12a & Infiltration Trench & 1137.56 \\
\hline S12b & Infiltration Trench & 351.76 \\
\hline S13 & Infiltration Trench & 85.55 \\
\hline S15 & Infiltration Trench & 200.00 \\
\hline S16 & Infiltration Trench & 575.55 \\
\hline S17 & Infiltration Trench & 247.92 \\
\hline S18 & Infiltration Trench & 923.59 \\
\hline S19 & Infiltration Trench & 186.55 \\
\hline S20 & Infiltration Trench & 491.08 \\
\hline S21 & Infiltration Trench & 646.03 \\
\hline S22 & Infiltration Trench & 807.85 \\
\hline S23 & Retention Pond & 525.00 \\
\hline S24 & Infiltration Trench & 1053.98 \\
\hline
\end{tabular}


Table 15.10 Case 8 LID BMP Areas

\begin{tabular}{|c|c|c|}
\hline SUBCATCHMENT & LID BMPs & $\begin{array}{l}\text { AREA } \\
(\mathrm{m} 2)\end{array}$ \\
\hline S6 & Infiltration Trench & 1083.80 \\
\hline S6 & Retention Pond & 812.85 \\
\hline S7 & Infiltration Trench & 375.18 \\
\hline S8 & Retention Pond & 320.00 \\
\hline S8 & Infiltration Trench & 426.67 \\
\hline S9 & Retention Pond & 393.83 \\
\hline S9 & Infiltration Trench & 525.10 \\
\hline S10 & Infiltration Trench & 2414.56 \\
\hline S11a & Retention Pond & 420.59 \\
\hline S11a & Vegetative Swale & 493.20 \\
\hline S11b & Infiltration Trench & 715.15 \\
\hline S12a & Retention Pond & 853.17 \\
\hline S12a & Vegetative Swale & 708.90 \\
\hline $\mathrm{S} 12 \mathrm{~b}$ & Infiltration Trench & 351.76 \\
\hline S13 & Infiltration Trench & 85.55 \\
\hline S15 & Infiltration Trench & 200.00 \\
\hline S16 & Infiltration Trench & 575.55 \\
\hline S17 & Infiltration Trench & 247.92 \\
\hline S18 & Infiltration Trench & 923.59 \\
\hline S19 & Infiltration Trench & 186.55 \\
\hline S20 & Infiltration Trench & 491.08 \\
\hline S21 & Infiltration Trench & 646.03 \\
\hline S22 & Infiltration Trench & 807.85 \\
\hline S23 & Retention Pond & 525.00 \\
\hline S24 & Vegetative Swale & 625.88 \\
\hline
\end{tabular}


Table 15.11 Case 9 LID BMP Areas

\begin{tabular}{|l|l|r|} 
& & \\
SUBCATCHMENT & \multicolumn{1}{c|}{ LID BMPS } \\
\hline S5 & Retention Pond & ( 2$)$ \\
\hline S5 & Infiltration Trench & 1651.35 \\
\hline S6 & Infiltration Trench & 1083.80 \\
\hline S6 & Retention Pond & 812.85 \\
\hline S7 & Vegetative Swale & 387.30 \\
\hline S8 & Retention Pond & 320.00 \\
\hline S8 & Infiltration Trench & 426.67 \\
\hline S9 & Retention Pond & 393.83 \\
\hline S9 & Infiltration Trench & 525.10 \\
\hline S10 & Infiltration Trench & 2414.56 \\
\hline S11a & Retention Pond & 420.59 \\
\hline S11a & Infiltration Trench & 560.79 \\
\hline S11b & Infiltration Trench & 715.15 \\
\hline S12a & Retention Pond & 853.17 \\
\hline S12a & Infiltration Trench & 1137.56 \\
\hline S12b & Infiltration Trench & 351.76 \\
\hline S13 & Infiltration Trench & 85.55 \\
\hline S15 & Infiltration Trench & 200.00 \\
\hline S16 & Infiltration Trench & 575.55 \\
\hline S17 & Infiltration Trench & 247.92 \\
\hline S18 & Infiltration Trench & 923.59 \\
\hline S19 & Infiltration Trench & 186.55 \\
\hline S20 & Infiltration Trench & 491.08 \\
\hline S21 & Infiltration Trench & 646.03 \\
\hline S22 & Infiltration Trench & 807.85 \\
\hline S23 & Retention Pond & 525.00 \\
\hline S24 & Vegetative Swale & 625.88 \\
\hline
\end{tabular}


Table 15.12 Case 10 LID BMP Areas

\begin{tabular}{|c|c|c|}
\hline SUBCATCHMENT & LID BMPs & $\begin{array}{l}\text { AREA } \\
(\mathrm{m} 2)\end{array}$ \\
\hline S1 & Infiltration Trench & 1725.30 \\
\hline S2 & Infiltration Trench & 520.00 \\
\hline S4 & Infiltration Trench & 790.07 \\
\hline S4 & Retention Pond & 592.55 \\
\hline S5 & Retention Pond & 1238.51 \\
\hline S5 & Infiltration Trench & 1651.35 \\
\hline S6 & Infiltration Trench & 1083.80 \\
\hline S6 & Retention Pond & 812.85 \\
\hline S7 & Infiltration Trench & 375.18 \\
\hline S8 & Retention Pond & 320.00 \\
\hline S8 & Infiltration Trench & 426.67 \\
\hline S9 & Retention Pond & 393.83 \\
\hline S9 & Infiltration Trench & 525.10 \\
\hline S10 & Infiltration Trench & 2414.56 \\
\hline S11a & Retention Pond & 420.59 \\
\hline S11a & Infiltration Trench & 560.79 \\
\hline S11b & Infiltration Trench & 715.15 \\
\hline S12a & Retention Pond & 853.17 \\
\hline S12a & Infiltration Trench & 1137.56 \\
\hline S12b & Infiltration Trench & 351.76 \\
\hline S13 & Infiltration Trench & 85.55 \\
\hline S15 & Infiltration Trench & 200.00 \\
\hline S16 & Infiltration Trench & 575.55 \\
\hline S17 & Infiltration Trench & 247.92 \\
\hline S18 & Infiltration Trench & 923.59 \\
\hline S19 & Infiltration Trench & 186.55 \\
\hline S20 & Infiltration Trench & 491.08 \\
\hline S21 & Infiltration Trench & 646.03 \\
\hline S22 & Infiltration Trench & 807.85 \\
\hline$S 23$ & Retention Pond & 525.00 \\
\hline S24 & Vegetative Swale & 625.88 \\
\hline
\end{tabular}




\subsection{Appendix D: Maintenance Probability Factor (MPF) Tables}

Table 15.13 Case 1 MPF Values per Subcatchment and Average per Case

\begin{tabular}{|c|c|c|}
\hline SUBCATCHMENT & LAND USE TYPE & MPF \\
\hline $\mathrm{S} 12 \mathrm{~b}$ & Med - residential & 3 \\
\hline S13 & Med - residential & 3 \\
\hline S16 & Institutional & 4 \\
\hline S18 & Med - residential & 3 \\
\hline S21 & Med - residential & 3 \\
\hline \multirow[t]{2}{*}{ S23 } & Med - residential & 3 \\
\hline & LAND USE VALUE & 3.17 \\
\hline
\end{tabular}

Table 15.14 Case 2 MPF Values per Subcatchment and Average per Case

\begin{tabular}{|c|c|c|}
\hline SUBCATCHMENT & LAND USE TYPE & MPF \\
\hline S12b & Med - residential & 3 \\
\hline S13 & Med - residential & 3 \\
\hline S16 & Institutional & 4 \\
\hline S18 & Med - residential & 3 \\
\hline S19 & Med - residential & 3 \\
\hline S20 & Med - residential & 3 \\
\hline S21 & Med - residential & 3 \\
\hline S22 & Med - residential & 3 \\
\hline S23 & Agricultural & 1 \\
\hline \multirow[t]{2}{*}{ S24 } & Med - residential & 3 \\
\hline & LAND USE VALUE & 2.90 \\
\hline
\end{tabular}


Table 15.15 Case 3 MPF Values per Subcatchment and Average per Case

\begin{tabular}{|c|c|c|}
\hline SUBCATCHMENT & LAND USE TYPE & MPF \\
\hline S11a & Low - residential & 2 \\
\hline S11a & Low - residential & 2 \\
\hline S12a & Low - residential & 2 \\
\hline S12a & Low - residential & 2 \\
\hline S12b & Med - residential & 3 \\
\hline S13 & Med - residential & 3 \\
\hline S16 & Institutional & 4 \\
\hline S18 & Med - residential & 3 \\
\hline S19 & Med - residential & 3 \\
\hline S20 & Med - residential & 3 \\
\hline S21 & Med - residential & 3 \\
\hline S22 & Med - residential & 3 \\
\hline S23 & Agricultural & 1 \\
\hline \multirow[t]{2}{*}{ S24 } & Med - residential & 3 \\
\hline & LAND USE VALUE & 2.64 \\
\hline
\end{tabular}

Table 15.16 Case 4 MPF Values per Subcatchment and Average per Case

\begin{tabular}{|c|c|c|}
\hline SUBCATCHMENT & LAND USE TYPE & MPF \\
\hline S11a & Low - residential & 2 \\
\hline S11a & Low - residential & 2 \\
\hline S11b & Low - residential & 2 \\
\hline S12a & Low - residential & 2 \\
\hline S12a & Low - residential & 2 \\
\hline S12b & Med - residential & 3 \\
\hline S13 & Med - residential & 3 \\
\hline S16 & Institutional & 4 \\
\hline S18 & Med - residential & 3 \\
\hline S19 & Med - residential & 3 \\
\hline S20 & Med - residential & 3 \\
\hline S21 & Med - residential & 3 \\
\hline S22 & Med - residential & 3 \\
\hline S23 & Agricultural & 1 \\
\hline \multirow[t]{2}{*}{ S24 } & Med - residential & 3 \\
\hline & LAND USE VALUE & 2.60 \\
\hline
\end{tabular}


Table 15.17 Case 5 MPF Values per Subcatchment and Average per Case

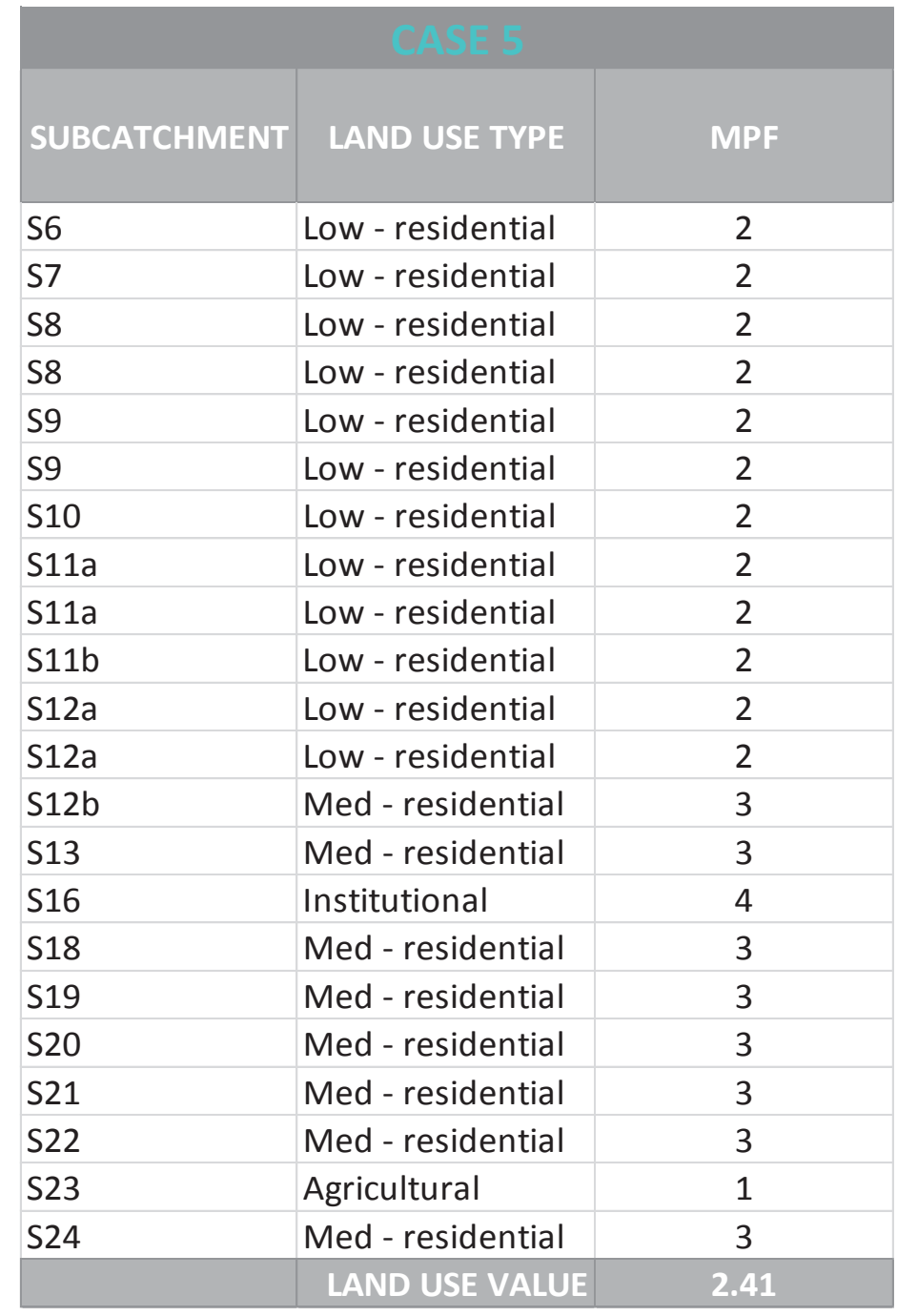


Table 15.18 Case 6 MPF Values per Subcatchment and Average per Case

\begin{tabular}{|c|c|c|}
\hline SUBCATCHMENT & LAND USE TYPE & MPF \\
\hline S6 & Low - residential & 2 \\
\hline S7 & Low - residential & 2 \\
\hline S8 & Low - residential & 2 \\
\hline S8 & Low - residential & 2 \\
\hline S9 & Low - residential & 2 \\
\hline S9 & Low - residential & 2 \\
\hline S10 & Low - residential & 2 \\
\hline S11a & Low - residential & 2 \\
\hline S11a & Low - residential & 2 \\
\hline S11b & Low - residential & 2 \\
\hline S12a & Low - residential & 2 \\
\hline S12a & Low - residential & 2 \\
\hline $\mathrm{S} 12 \mathrm{~b}$ & Med - residential & 3 \\
\hline S13 & Med - residential & 3 \\
\hline S16 & Insitutional & 4 \\
\hline S18 & Med - residential & 3 \\
\hline S19 & Med - residential & 3 \\
\hline S20 & Med - residential & 3 \\
\hline S21 & Med - residential & 3 \\
\hline S22 & Med - residential & 3 \\
\hline S23 & Agricultural & 1 \\
\hline \multirow[t]{2}{*}{ S24 } & Med - residential & 3 \\
\hline & LAND USE VALUE & 2.41 \\
\hline
\end{tabular}


Table 15.19 Case 7 MPF Values per Subcatchment and Average per Case

\begin{tabular}{|c|c|c|}
\hline SUBCATCHMENT & LAND USE TYPE & MPF \\
\hline S6 & Low - residential & 2 \\
\hline S7 & Low - residential & 2 \\
\hline S8 & Low - residential & 2 \\
\hline S8 & Low - residential & 2 \\
\hline S9 & Low - residential & 2 \\
\hline S9 & Low - residential & 2 \\
\hline S10 & Low - residential & 2 \\
\hline S11a & Low - residential & 2 \\
\hline S11a & Low - residential & 2 \\
\hline S11b & Low - residential & 2 \\
\hline S12a & Low - residential & 2 \\
\hline S12a & Low - residential & 2 \\
\hline $\mathrm{S} 12 \mathrm{~b}$ & Med - residential & 3 \\
\hline S13 & Med - residential & 3 \\
\hline S15 & Institutional & 4 \\
\hline S16 & Institutional & 4 \\
\hline S17 & Institutional & 4 \\
\hline S18 & Med - residential & 3 \\
\hline S19 & Med - residential & 3 \\
\hline S20 & Med - residential & 3 \\
\hline S21 & Med - residential & 3 \\
\hline S22 & Med - residential & 3 \\
\hline S23 & Agricultural & 1 \\
\hline \multirow[t]{2}{*}{ S24 } & Med - residential & 3 \\
\hline & LAND USE VALUE & 2.54 \\
\hline
\end{tabular}


Table 15.20 Case 9 MPF Values per Subcatchment and Average per Case

\begin{tabular}{|l|l|l|}
\hline & & \\
\hline SUBCATCHMENT & LAND USE TYPE & MPF \\
\hline S5 & Low - residential & 2 \\
\hline S5 & Low - residential & 2 \\
\hline S6 & Low - residential & 2 \\
\hline S6 & Low - residential & 2 \\
\hline S7 & Low - residential & 2 \\
\hline S8 & Low - residential & 2 \\
\hline S8 & Low - residential & 2 \\
\hline S9 & Low - residential & 2 \\
\hline S9 & Low - residential & 2 \\
\hline S10 & Low - residential & 2 \\
\hline S11a & Low - residential & 2 \\
\hline S11a & Low - residential & 2 \\
\hline S11b & Low - residential & 2 \\
\hline S12a & Low - residential & 2 \\
\hline S12a & Low - residential & 2 \\
\hline S12b & Med - residential & 3 \\
\hline S13 & Med - residential & 3 \\
\hline S15 & Institutional & 4 \\
\hline S16 & Institutional & 4 \\
\hline S17 & Institutional & 4 \\
\hline S18 & Med - residential & 3 \\
\hline S19 & Med - residential & 3 \\
\hline S20 & Med - residential & 3 \\
\hline S21 & Med - residential & 3 \\
\hline S22 & 3 \\
\hline S23 & LAND UsE VALUE & 2.48 \\
\hline S24 & \\
\hline & & 3 \\
\hline
\end{tabular}


Table 15.21 Case 10 MPF Values per Subcatchment and Average per Case

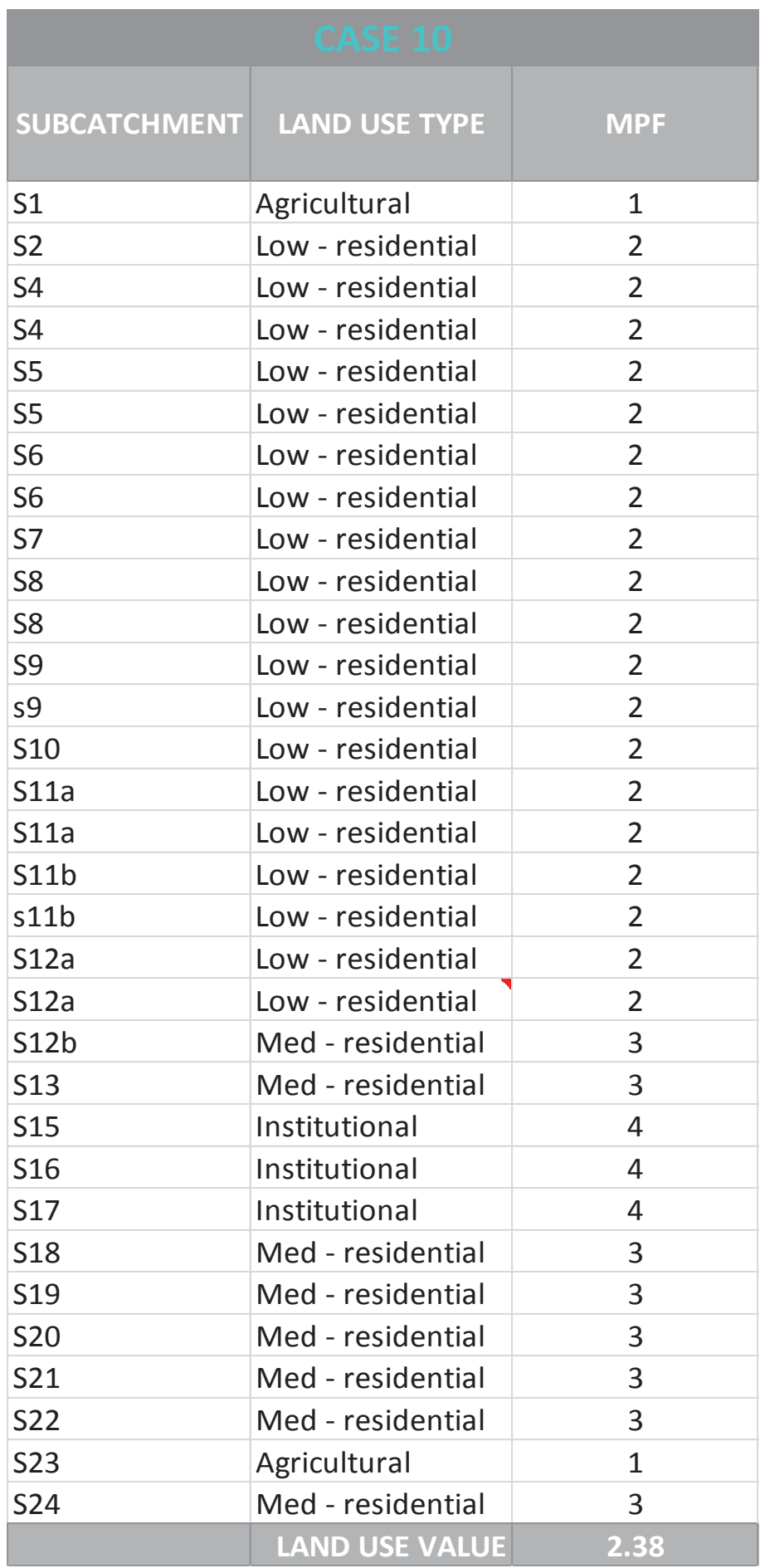




\subsection{Appendix E: SWMM 5.1 Runoff Results for all Cases}

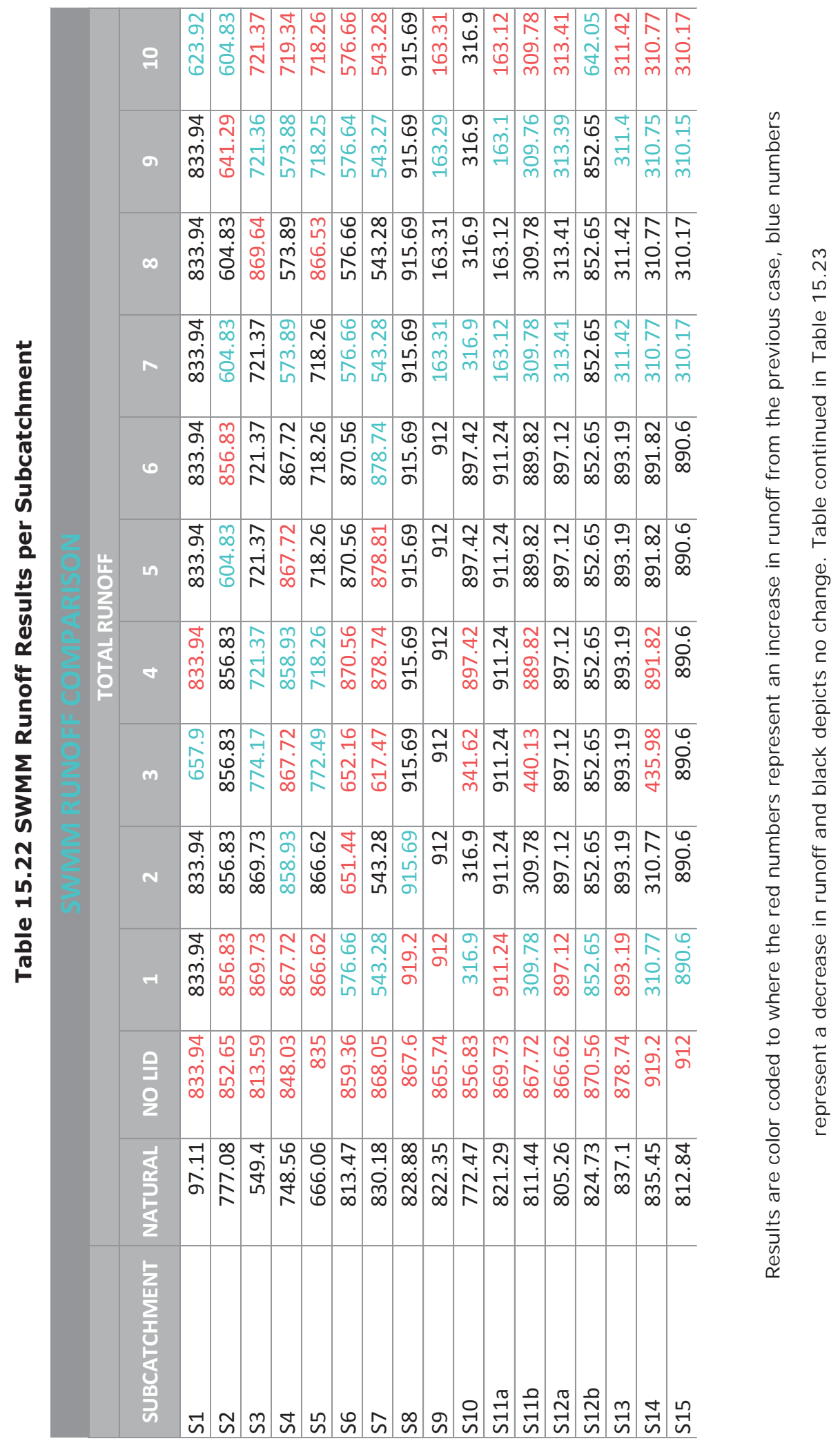




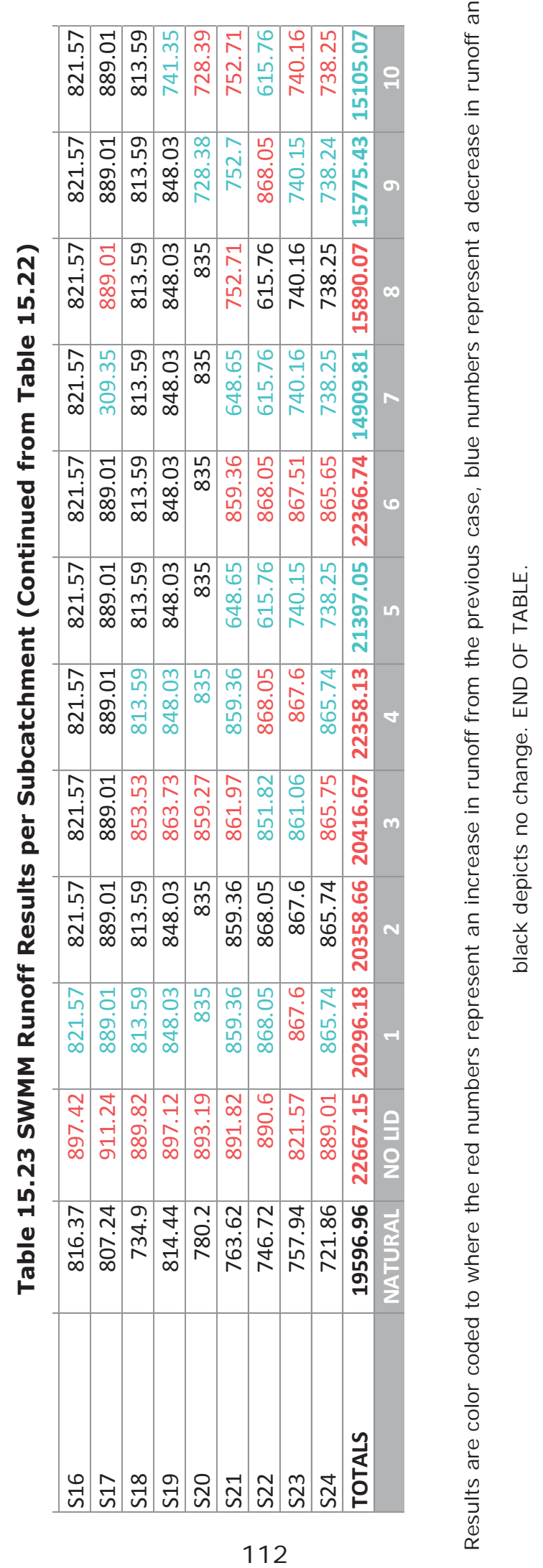




\subsection{Appendix F: SWMM 5.1 Detailed Results by Case}

Table 15.24 Natural Case SWMM Results

\begin{tabular}{|c|c|c|c|c|c|c|}
\hline & $\begin{array}{c}\text { Total } \\
\text { Precipitation }\end{array}$ & $\begin{array}{l}\text { Total } \\
\text { Infill }\end{array}$ & $\begin{array}{l}\text { Total } \\
\text { Runoff }\end{array}$ & $\begin{array}{l}\text { Total } \\
\text { Runoff }\end{array}$ & $\begin{array}{l}\text { Peak } \\
\text { Runoff }\end{array}$ & Runoff \\
\hline Subcatchment & $\mathrm{mm}$ & $\mathrm{mm}$ & $\mathrm{mm}$ & $10^{\wedge} \sigma \mathrm{Itr}$ & CMS & Coeff \\
\hline S1 & 925.5 & 705.03 & 97.11 & 16755.2 & 1.51 & 0.105 \\
\hline S2 & 925.5 & 66.44 & 777.08 & 40408.32 & 5.52 & 0.84 \\
\hline S3 & 925.5 & 66.44 & 549.4 & 176427.49 & 13.89 & 0.594 \\
\hline S4 & 925.5 & 66.44 & 748.56 & 59141.7 & 7.08 & 0.809 \\
\hline S5 & 925.5 & 66.44 & 666.06 & 109989.81 & 10.56 & 0.72 \\
\hline S6 & 925.5 & 66.44 & 813.47 & 88164.33 & 16.76 & 0.879 \\
\hline S7 & 925.5 & 66.44 & 830.18 & 31140.39 & 8.51 & 0.897 \\
\hline S8 & 925.5 & 66.44 & 828.88 & 35365.83 & 9.28 & 0.896 \\
\hline S9 & 925.5 & 66.44 & 822.35 & 43181.94 & 9.6 & 0.889 \\
\hline S10 & 925.5 & 66.44 & 772.47 & 186518.24 & 24.86 & 0.835 \\
\hline S11a & 925.5 & 66.44 & 821.29 & 46057.41 & 10.02 & 0.887 \\
\hline S11b & 925.5 & 66.44 & 811.44 & 58030.62 & 10.72 & 0.877 \\
\hline S12a & 925.5 & 66.44 & 805.26 & 91603.23 & 15.67 & 0.87 \\
\hline $\mathrm{S} 12 \mathrm{~b}$ & 925.5 & 66.44 & 824.73 & 29010.84 & 6.81 & 0.891 \\
\hline S13 & 925.5 & 66.44 & 837.1 & 7161.4 & 2.58 & 0.904 \\
\hline S14 & 925.5 & 66.44 & 835.45 & 2782.06 & 0.93 & 0.903 \\
\hline S15 & 925.5 & 66.44 & 812.84 & 16256.8 & 3.06 & 0.878 \\
\hline S16 & 925.5 & 66.44 & 816.37 & 46986.61 & 9.34 & 0.882 \\
\hline S17 & 925.5 & 66.44 & 807.24 & 20013.21 & 3.5 & 0.872 \\
\hline S18 & 925.5 & 66.44 & 734.9 & 67875.28 & 7.75 & 0.794 \\
\hline S19 & 925.5 & 66.44 & 814.44 & 15193.39 & 2.93 & 0.88 \\
\hline S20 & 925.5 & 66.44 & 780.2 & 38314.51 & 5.34 & 0.843 \\
\hline $\mathrm{S} 21$ & 925.5 & 66.44 & 763.62 & 49332.51 & 6.29 & 0.825 \\
\hline S22 & 925.5 & 66.44 & 746.72 & 60324.35 & 7.17 & 0.807 \\
\hline S23 & 925.5 & 66.44 & 757.94 & 53055.96 & 6.6 & 0.819 \\
\hline S24 & 925.5 & 66.44 & 721.86 & 76083.36 & 8.36 & 0.78 \\
\hline
\end{tabular}


Table 15.25 Road Case SWMM Results

\begin{tabular}{|c|c|c|c|c|c|c|}
\hline & \begin{tabular}{c|} 
Total \\
Precipit \\
ation
\end{tabular} & $\begin{array}{l}\text { Total } \\
\text { Infill }\end{array}$ & $\begin{array}{l}\text { Total } \\
\text { Runoff }\end{array}$ & $\begin{array}{l}\text { Total } \\
\text { Runoff }\end{array}$ & $\begin{array}{l}\text { Peak } \\
\text { Runoff }\end{array}$ & Runoff \\
\hline Subcatchment & $\mathrm{mm}$ & $\mathrm{mm}$ & $\mathrm{mm}$ & $10^{\wedge} 6 \mathrm{ltr}$ & CMS & Coeff \\
\hline S1 & 925.5 & 49.83 & 833.94 & 143880.2 & 35.28 & 0.901 \\
\hline S2 & 925.5 & 49.83 & 852.65 & 44338.22 & 14.47 & 0.921 \\
\hline S3 & 925.5 & 49.83 & 813.59 & 261268.1 & 54.34 & 0.879 \\
\hline S4 & 925.5 & 49.83 & 848.03 & 67001 & 19.94 & 0.916 \\
\hline S5 & 925.5 & 49.83 & 835 & 137887.8 & 34.2 & 0.902 \\
\hline S6 & 925.5 & 49.83 & 859.36 & 93138.4 & 36.83 & 0.929 \\
\hline S7 & 925.5 & 46.51 & 868.05 & 32560.65 & 15.81 & 0.938 \\
\hline S8 & 925.5 & 46.51 & 867.6 & 37018.22 & 17.65 & 0.937 \\
\hline S9 & 925.5 & 46.51 & 865.74 & 45460.52 & 20.1 & 0.935 \\
\hline S10 & 925.5 & 46.51 & 856.83 & 206888.1 & 69.61 & 0.926 \\
\hline S11a & 925.5 & 43.19 & 869.73 & 48773.82 & 21.96 & 0.94 \\
\hline S11b & 925.5 & 43.19 & 867.72 & 62055.43 & 25.98 & 0.938 \\
\hline S12a & 925.5 & 43.19 & 866.62 & 98584.31 & 39.79 & 0.936 \\
\hline S12b & 925.5 & 43.19 & 870.56 & 30623.15 & 14.24 & 0.941 \\
\hline S13 & 925.5 & 39.86 & 878.74 & 7517.64 & 4.12 & 0.949 \\
\hline S14 & 925.5 & 3.32 & 919.2 & 3060.95 & 1.68 & 0.993 \\
\hline S15 & 925.5 & 6.64 & 912 & 18240.05 & 9.38 & 0.985 \\
\hline S16 & 925.5 & 19.93 & 897.42 & 51651.3 & 26.15 & 0.97 \\
\hline S17 & 925.5 & 6.64 & 911.24 & 22591.6 & 11.32 & 0.985 \\
\hline $\mathrm{S} 18$ & 925.5 & 19.93 & 889.82 & 82183.48 & 30.76 & 0.961 \\
\hline S19 & 925.5 & 19.93 & 897.12 & 16735.89 & 8.39 & 0.969 \\
\hline S20 & 925.5 & 19.93 & 893.19 & 43863.06 & 18.92 & 0.965 \\
\hline$S 21$ & 925.5 & 19.93 & 891.82 & 57614.5 & 23.45 & 0.964 \\
\hline $\mathrm{S} 22$ & 925.5 & 19.93 & 890.6 & 71947.6 & 27.81 & 0.962 \\
\hline $\mathrm{S} 23$ & 925.5 & 66.44 & 821.57 & 57510.45 & 11.94 & 0.888 \\
\hline S24 & 925.5 & 19.93 & 889.01 & 93700.46 & 33.93 & 0.961 \\
\hline
\end{tabular}


Table 15.26 Case 1 SWMM Results

\begin{tabular}{|c|c|c|c|c|c|c|}
\hline & $\begin{array}{c}\text { Total } \\
\text { Precipitation }\end{array}$ & $\begin{array}{l}\text { Total } \\
\text { Inffll }\end{array}$ & $\begin{array}{l}\text { Total } \\
\text { Runoff }\end{array}$ & $\begin{array}{l}\text { Total } \\
\text { Runoff }\end{array}$ & $\begin{array}{l}\text { Peak } \\
\text { Runoff }\end{array}$ & Runoff \\
\hline Subcatchment & $\mathrm{mm}$ & $\mathrm{mm}$ & $\mathrm{mm}$ & $10^{\wedge} \sigma \mathrm{ltr}$ & CMS & Coeff \\
\hline S1 & 925.5 & 49.83 & 833.94 & 143880.2 & 35.28 & 0.901 \\
\hline S2 & 925.5 & 49.83 & 852.65 & 44338.22 & 14.47 & 0.921 \\
\hline S3 & 925.5 & 49.83 & 813.59 & 261268.1 & 54.34 & 0.879 \\
\hline S4 & 925.5 & 49.83 & 848.03 & 67001 & 19.94 & 0.916 \\
\hline S5 & 925.5 & 49.83 & 835 & 137887.8 & 34.2 & 0.902 \\
\hline S6 & 925.5 & 49.83 & 859.36 & 93138.4 & 36.83 & 0.929 \\
\hline S7 & 925.5 & 46.51 & 868.05 & 32560.65 & 15.81 & 0.938 \\
\hline S8 & 925.5 & 46.51 & 867.6 & 37018.22 & 17.65 & 0.937 \\
\hline S9 & 925.5 & 46.51 & 865.74 & 45460.52 & 20.1 & 0.935 \\
\hline S10 & 925.5 & 46.51 & 856.83 & 206888.1 & 69.61 & 0.926 \\
\hline S11a & 925.5 & 43.19 & 869.73 & 48773.82 & 21.96 & 0.94 \\
\hline S11b & 925.5 & 43.19 & 867.72 & 62055.43 & 25.98 & 0.938 \\
\hline S12a & 925.5 & 43.19 & 866.62 & 98584.31 & 39.79 & 0.936 \\
\hline $\mathrm{S} 12 \mathrm{~b}$ & 925.5 & 85.91 & 576.66 & 20284.62 & 8.64 & 0.623 \\
\hline S13 & 925.5 & 78.73 & 543.28 & 4647.77 & 2.56 & 0.587 \\
\hline S14 & 925.5 & 3.32 & 919.2 & 3060.95 & 1.68 & 0.993 \\
\hline S15 & 925.5 & 6.64 & 912 & 18240.05 & 9.38 & 0.985 \\
\hline S16 & 925.5 & 29.5 & 316.9 & 18239.25 & 8.45 & 0.342 \\
\hline S17 & 925.5 & 6.64 & 911.24 & 22591.6 & 11.32 & 0.985 \\
\hline S18 & 925.5 & 78.42 & 309.78 & 28610.79 & 8.91 & 0.335 \\
\hline S19 & 925.5 & 19.93 & 897.12 & 16735.89 & 8.39 & 0.969 \\
\hline S20 & 925.5 & 19.93 & 893.19 & 43863.06 & 18.92 & 0.965 \\
\hline S21 & 925.5 & 77.93 & 310.77 & 20076.58 & 6.91 & 0.336 \\
\hline $\mathrm{S} 22$ & 925.5 & 19.93 & 890.6 & 71947.6 & 27.81 & 0.962 \\
\hline S23 & 925.5 & 66.45 & 821.57 & 57510.02 & 11.94 & 0.888 \\
\hline S24 & 925.5 & 19.93 & 889.01 & 93700.46 & 33.93 & 0.961 \\
\hline
\end{tabular}


Table 15.27 Case 2 SWMM Results

\begin{tabular}{|c|c|c|c|c|c|c|}
\hline & $\begin{array}{l}\text { Total } \\
\text { Percipitation }\end{array}$ & $\begin{array}{l}\text { Total } \\
\text { Infill }\end{array}$ & $\begin{array}{l}\text { Total } \\
\text { Runoff }\end{array}$ & $\begin{array}{l}\text { Total } \\
\text { Runoff }\end{array}$ & $\begin{array}{l}\text { Peak } \\
\text { Runoff }\end{array}$ & Runoff \\
\hline Subcatchment & $\mathrm{mm}$ & $\mathrm{mm}$ & $\mathrm{mm}$ & $10^{\wedge} \sigma \mathrm{ltr}$ & CMS & Coeff \\
\hline S1 & 925.5 & 49.83 & 833.94 & 143880.2 & 35.28 & 0.901 \\
\hline S2 & 925.5 & 49.83 & 852.65 & 44338.22 & 14.47 & 0.921 \\
\hline S3 & 925.5 & 49.83 & 813.59 & 261268.1 & 54.34 & 0.879 \\
\hline S4 & 925.5 & 49.83 & 848.03 & 67001 & 19.94 & 0.916 \\
\hline S5 & 925.5 & 49.83 & 835 & 137887.8 & 34.2 & 0.902 \\
\hline S6 & 925.5 & 49.83 & 859.36 & 93138.4 & 36.83 & 0.929 \\
\hline S7 & 925.5 & 46.51 & 868.05 & 32560.65 & 15.81 & 0.938 \\
\hline S8 & 925.5 & 46.51 & 867.6 & 37018.22 & 17.65 & 0.937 \\
\hline S9 & 925.5 & 46.51 & 865.74 & 45460.52 & 20.1 & 0.935 \\
\hline S10 & 925.5 & 46.51 & 856.83 & 206888.1 & 69.61 & 0.926 \\
\hline S11a & 925.5 & 43.19 & 869.73 & 48773.82 & 21.96 & 0.94 \\
\hline S11b & 925.5 & 49.83 & 858.93 & 61426.85 & 23.92 & 0.928 \\
\hline S12a & 925.5 & 43.19 & 866.62 & 98584.31 & 39.79 & 0.936 \\
\hline $\mathrm{S} 12 \mathrm{~b}$ & 925.5 & 88.8 & 651.44 & 22915.27 & 9.37 & 0.704 \\
\hline S13 & 925.5 & 78.73 & 543.28 & 4647.77 & 2.56 & 0.587 \\
\hline S14 & 925.5 & 6.64 & 915.69 & 3049.27 & 1.68 & 0.989 \\
\hline S15 & 925.5 & 6.64 & 912 & 18240.05 & 9.38 & 0.985 \\
\hline S16 & 925.5 & 29.5 & 316.9 & 18239.25 & 8.45 & 0.342 \\
\hline S17 & 925.5 & 6.64 & 911.24 & 22591.6 & 11.32 & 0.985 \\
\hline S18 & 925.5 & 78.42 & 309.78 & 28610.79 & 8.91 & 0.335 \\
\hline S19 & 925.5 & 19.93 & 897.12 & 16735.87 & 8.39 & 0.969 \\
\hline S20 & 925.5 & 19.93 & 893.19 & 43862.96 & 18.92 & 0.965 \\
\hline S21 & 925.5 & 77.93 & 310.77 & 20076.58 & 6.91 & 0.336 \\
\hline S22 & 925.5 & 19.93 & 890.6 & 71947.56 & 27.81 & 0.962 \\
\hline S23 & 925.5 & 66.45 & 821.57 & 57510.02 & 11.94 & 0.888 \\
\hline S24 & 925.5 & 19.93 & 889.01 & 93700.3 & 33.92 & 0.961 \\
\hline
\end{tabular}


Table 15.28 Case 3 SWMM Results

\begin{tabular}{|c|c|c|c|c|c|c|}
\hline & $\begin{array}{c}\text { Total } \\
\text { Percipitation }\end{array}$ & $\begin{array}{l}\text { Total } \\
\text { Infill }\end{array}$ & $\begin{array}{l}\text { Total } \\
\text { Runoff }\end{array}$ & $\begin{array}{l}\text { Total } \\
\text { Runoff }\end{array}$ & $\begin{array}{l}\text { Peak } \\
\text { Runoff }\end{array}$ & Runoff \\
\hline Subcatchment & $\mathrm{mm}$ & $\mathrm{mm}$ & $\mathrm{mm}$ & $10^{\wedge} \sigma \mathrm{Itr}$ & CMS & Coeff \\
\hline S1 & 925.5 & 49.83 & 657.9 & 113507.6 & 14.8 & 0.711 \\
\hline S2 & 925.5 & 49.83 & 852.65 & 44338.22 & 14.47 & 0.921 \\
\hline S3 & 925.5 & 49.83 & 853.53 & 274091.8 & 75.88 & 0.922 \\
\hline S4 & 925.5 & 49.83 & 863.73 & 68240.79 & 27.69 & 0.933 \\
\hline S5 & 925.5 & 49.83 & 859.27 & 141896.7 & 47.62 & 0.928 \\
\hline S6 & 925.5 & 49.83 & 861.97 & 93421.16 & 35.06 & 0.931 \\
\hline S7 & 925.5 & 68.8 & 851.82 & 31951.86 & 15.43 & 0.92 \\
\hline S8 & 925.5 & 59.12 & 861.06 & 36739.26 & 17.13 & 0.93 \\
\hline S9 & 925.5 & 49.83 & 865.75 & 45460.98 & 20.21 & 0.935 \\
\hline S10 & 925.5 & 46.51 & 856.83 & 206888.1 & 69.61 & 0.926 \\
\hline S11a & 925.5 & 65.22 & 774.17 & 43414.99 & 17.83 & 0.836 \\
\hline S11b & 925.5 & 43.19 & 867.72 & 62055.43 & 25.98 & 0.938 \\
\hline S12a & 925.5 & 67.76 & 772.49 & 87875.96 & 31.57 & 0.835 \\
\hline $\mathrm{S} 12 \mathrm{~b}$ & 925.5 & 61.71 & 652.16 & 22940.69 & 8.85 & 0.705 \\
\hline S13 & 925.5 & 54.48 & 617.47 & 5282.46 & 2.61 & 0.667 \\
\hline S14 & 925.5 & 6.64 & 915.69 & 3049.27 & 1.68 & 0.989 \\
\hline S15 & 925.5 & 6.64 & 912 & 18240.05 & 9.38 & 0.985 \\
\hline S16 & 925.5 & 21.21 & 341.62 & 19661.79 & 8.5 & 0.369 \\
\hline S17 & 925.5 & 6.64 & 911.24 & 22591.6 & 11.32 & 0.985 \\
\hline S18 & 925.5 & 37.11 & 440.13 & 40650.2 & 9.45 & 0.476 \\
\hline S19 & 925.5 & 19.93 & 897.12 & 16735.87 & 8.39 & 0.969 \\
\hline S20 & 925.5 & 19.93 & 893.19 & 43863.02 & 18.92 & 0.965 \\
\hline S21 & 925.5 & 38.35 & 435.98 & 28165.73 & 7.29 & 0.471 \\
\hline $\mathrm{S} 22$ & 925.5 & 19.93 & 890.6 & 71947.56 & 27.81 & 0.962 \\
\hline S23 & 925.5 & 66.45 & 821.57 & 57510.02 & 11.94 & 0.888 \\
\hline S24 & 925.5 & 19.93 & 889.01 & 93700.42 & 33.93 & 0.961 \\
\hline
\end{tabular}


Table 15.29 Case 4 SWMM Results

\begin{tabular}{|c|c|c|c|c|c|c|}
\hline & $\begin{array}{c}\text { Total } \\
\text { Percipitation }\end{array}$ & $\begin{array}{l}\text { Total } \\
\text { Infill }\end{array}$ & $\begin{array}{l}\text { Total } \\
\text { Runoff }\end{array}$ & $\begin{array}{l}\text { Total } \\
\text { Runoff }\end{array}$ & $\begin{array}{l}\text { Peak } \\
\text { Runoff }\end{array}$ & Runoff \\
\hline Subcatchment & $\mathrm{mm}$ & $\mathrm{mm}$ & $\mathrm{mm}$ & $10^{\wedge} \mathrm{G} \mathrm{Itr}$ & CMS & Coeff \\
\hline S1 & 925.5 & 49.83 & 833.94 & 143880.2 & 35.28 & 0.901 \\
\hline S2 & 925.5 & 49.83 & 852.65 & 44338.22 & 14.47 & 0.921 \\
\hline S3 & 925.5 & 49.83 & 813.59 & 261268.1 & 54.34 & 0.879 \\
\hline S4 & 925.5 & 49.83 & 848.03 & 67001 & 19.94 & 0.916 \\
\hline S5 & 925.5 & 49.83 & 835 & 137887.8 & 34.2 & 0.902 \\
\hline S6 & 925.5 & 49.83 & 859.36 & 93138.4 & 36.83 & 0.929 \\
\hline S7 & 925.5 & 46.51 & 868.05 & 32560.65 & 15.81 & 0.938 \\
\hline S8 & 925.5 & 46.51 & 867.6 & 37018.22 & 17.65 & 0.937 \\
\hline S9 & 925.5 & 46.51 & 865.74 & 45460.52 & 20.1 & 0.935 \\
\hline S10 & 925.5 & 46.51 & 856.83 & 206888.1 & 69.61 & 0.926 \\
\hline S11a & 925.5 & 81.26 & 721.37 & 40453.9 & 17.5 & 0.779 \\
\hline S11b & 925.5 & 49.83 & 858.93 & 61426.79 & 23.92 & 0.928 \\
\hline S12a & 925.5 & 83.77 & 718.26 & 81706.83 & 30.9 & $0.77 \epsilon$ \\
\hline $\mathrm{S} 12 \mathrm{~b}$ & 925.5 & 43.19 & 870.56 & 30623.12 & 14.24 & 0.941 \\
\hline S13 & 925.5 & 39.86 & 878.74 & 7517.63 & 4.12 & 0.949 \\
\hline S14 & 925.5 & 6.64 & 915.69 & 3049.27 & 1.68 & 0.989 \\
\hline S15 & 925.5 & 6.64 & 912 & 18240.05 & 9.38 & 0.985 \\
\hline S16 & 925.5 & 19.93 & 897.42 & 51651.26 & 26.15 & 0.97 \\
\hline S17 & 925.5 & 6.64 & 911.24 & 22591.6 & 11.32 & 0.985 \\
\hline S18 & 925.5 & 19.93 & 889.82 & 82183.42 & 30.76 & 0.961 \\
\hline S19 & 925.5 & 19.93 & 897.12 & 16735.87 & 8.39 & 0.969 \\
\hline S20 & 925.5 & 19.93 & 893.19 & 43863.02 & 18.92 & 0.965 \\
\hline S21 & 925.5 & 19.93 & 891.82 & 57614.45 & 23.45 & 0.964 \\
\hline S22 & 925.5 & 19.93 & 890.6 & 71947.56 & 27.81 & 0.962 \\
\hline S23 & 925.5 & 66.45 & 821.57 & 57510.02 & 11.94 & 0.888 \\
\hline S24 & 925.5 & 19.93 & 889.01 & 93700.42 & 33.93 & 0.961 \\
\hline
\end{tabular}


Table 15.30 Case 5 SWMM Results

\begin{tabular}{|c|c|c|c|c|c|c|}
\hline & $\begin{array}{c}\text { Total } \\
\text { Percipitation }\end{array}$ & $\begin{array}{l}\text { Total } \\
\text { Inffll }\end{array}$ & $\begin{array}{l}\text { Total } \\
\text { Runoff }\end{array}$ & $\begin{array}{l}\text { Total } \\
\text { Runoff }\end{array}$ & $\begin{array}{l}\text { Peak } \\
\text { Runoff }\end{array}$ & Runoff \\
\hline Subcatchment & $\mathrm{mm}$ & $\mathrm{mm}$ & $\mathrm{mm}$ & $10^{\wedge} \sigma \mathrm{ltr}$ & CMS & Coeff \\
\hline S1 & 925.5 & 49.83 & 833.94 & 143880.2 & 35.28 & 0.901 \\
\hline S2 & 925.5 & 49.83 & 852.65 & 44338.22 & 14.47 & 0.921 \\
\hline S3 & 925.5 & 49.83 & 813.59 & 261268.1 & 54.34 & 0.879 \\
\hline S4 & 925.5 & 49.83 & 848.03 & 67001 & 19.94 & 0.916 \\
\hline S5 & 925.5 & 49.83 & 835 & $\mid 137887.8$ & 34.2 & 0.902 \\
\hline S6 & 925.5 & 91.1 & 648.65 & 70300.82 & 24.53 & 0.701 \\
\hline S7 & 925.5 & 85.76 & 615.76 & 23097.44 & 10.69 & 0.665 \\
\hline S8 & 925.5 & 81.08 & 740.15 & 31580.34 & 14.73 & 0.8 \\
\hline S9 & 925.5 & 82.49 & 738.25 & 38765.57 & 16.51 & 0.798 \\
\hline S10 & 925.5 & 95.02 & 604.83 & 146040.2 & 38.66 & 0.654 \\
\hline S11a & 925.5 & 81.26 & 721.37 & 40453.84 & 17.5 & 0.779 \\
\hline S11b & 925.5 & 43.19 & 867.72 & 62055.38 & 25.98 & 0.938 \\
\hline S12a & 925.5 & 83.77 & 718.26 & 81706.72 & 30.9 & 0.776 \\
\hline $\mathrm{S} 12 \mathrm{~b}$ & 925.5 & 43.19 & 870.56 & 30623.12 & 14.24 & 0.941 \\
\hline S13 & 925.5 & 39.86 & 878.81 & 7518.24 & 4.12 & 0.95 \\
\hline S14 & 925.5 & 6.64 & 915.69 & 3049.27 & 1.68 & 0.989 \\
\hline S15 & 925.5 & 6.64 & 912 & 18240.05 & 9.38 & 0.985 \\
\hline S16 & 925.5 & 19.93 & 897.42 & 51651.26 & 26.15 & 0.97 \\
\hline S17 & 925.5 & 6.64 & 911.24 & 22591.6 & 11.32 & 0.985 \\
\hline S18 & 925.5 & 19.93 & 889.82 & 82183.42 & 30.76 & 0.961 \\
\hline S19 & 925.5 & 19.93 & 897.12 & 16735.87 & 8.39 & 0.969 \\
\hline S20 & 925.5 & 19.93 & 893.19 & 43863.02 & 18.92 & 0.965 \\
\hline S21 & 925.5 & 19.93 & 891.82 & 57614.45 & 23.45 & 0.964 \\
\hline S22 & 925.5 & 19.93 & 890.6 & 71947.56 & 27.81 & 0.962 \\
\hline S23 & 925.5 & 66.45 & 821.57 & 57510.02 & 11.94 & 0.888 \\
\hline S24 & 925.5 & 19.93 & 889.01 & 93700.42 & 33.93 & 0.961 \\
\hline
\end{tabular}


Table 15.31 Case 6 SWMM Results

\begin{tabular}{|c|c|c|c|c|c|c|}
\hline & $\begin{array}{c}\text { Total } \\
\text { Percipitation }\end{array}$ & $\begin{array}{l}\text { Total } \\
\text { Inffill }\end{array}$ & $\begin{array}{l}\text { Total } \\
\text { Runoff }\end{array}$ & $\begin{array}{l}\text { Total } \\
\text { Runoff }\end{array}$ & $\begin{array}{c}\text { Peak } \\
\text { Runoff }\end{array}$ & Runoff \\
\hline Subcatchment & $\mathrm{mm}$ & $\mathrm{mm}$ & $\mathrm{mm}$ & $10^{\wedge} \sigma \mathrm{ltr}$ & CMS & Coeff \\
\hline S1 & 925.5 & 49.83 & 833.94 & 143880.2 & 35.28 & 0.901 \\
\hline S2 & 925.5 & 49.83 & 852.65 & 44338.22 & 14.47 & 0.921 \\
\hline S3 & 925.5 & 49.83 & 813.59 & 261268.1 & 54.34 & 0.879 \\
\hline S4 & 925.5 & 49.83 & 848.03 & 67001 & 19.94 & 0.916 \\
\hline S5 & 925.5 & 49.83 & 835 & 137887.8 & 34.2 & 0.902 \\
\hline S6 & 925.5 & 49.83 & 859.36 & 93138.34 & 36.83 & 0.929 \\
\hline S7 & 925.5 & 46.51 & 868.05 & 32560.62 & 15.81 & 0.938 \\
\hline S8 & 925.5 & 46.6 & 867.51 & 37014.24 & 17.65 & 0.937 \\
\hline S9 & 925.5 & 46.6 & 865.65 & 45455.64 & 20.1 & 0.935 \\
\hline S10 & 925.5 & 46.51 & 856.83 & 206888.1 & 69.61 & 0.926 \\
\hline S11a & 925.5 & 81.26 & 721.37 & 40453.9 & 17.5 & 0.779 \\
\hline S11b & 925.5 & 43.19 & 867.72 & 62055.38 & 25.98 & 0.938 \\
\hline S12a & 925.5 & 83.77 & 718.26 & 81706.83 & 30.9 & 0.776 \\
\hline $\mathrm{S} 12 \mathrm{~b}$ & 925.5 & 43.19 & 870.56 & 30623.12 & 14.24 & 0.941 \\
\hline S13 & 925.5 & 39.86 & 878.74 & 7517.63 & 4.12 & 0.949 \\
\hline S14 & 925.5 & 6.64 & 915.69 & 3049.27 & 1.68 & 0.989 \\
\hline S15 & 925.5 & 6.64 & 912 & 18240.05 & 9.38 & 0.985 \\
\hline S16 & 925.5 & 19.93 & 897.42 & 51651.26 & 26.15 & 0.97 \\
\hline S17 & 925.5 & 6.64 & 911.24 & 22591.6 & 11.32 & 0.985 \\
\hline S18 & 925.5 & 19.93 & 889.82 & 82183.42 & 30.76 & 0.961 \\
\hline S19 & 925.5 & 19.93 & 897.12 & 16735.87 & 8.39 & 0.969 \\
\hline S20 & 925.5 & 19.93 & 893.19 & 43863.02 & 18.92 & 0.965 \\
\hline S21 & 925.5 & 19.93 & 891.82 & 57614.45 & 23.45 & 0.964 \\
\hline S22 & 925.5 & 19.93 & 890.6 & 71947.56 & 27.81 & 0.962 \\
\hline S23 & 925.5 & 66.45 & 821.57 & 57510.02 & 11.94 & 0.888 \\
\hline S24 & 925.5 & 19.93 & 889.01 & 93700.42 & 33.93 & 0.961 \\
\hline
\end{tabular}


Table 15.32 Case 7 SWMM Results

\begin{tabular}{|c|c|c|c|c|c|c|}
\hline & $\begin{array}{c}\text { Total } \\
\text { Percipitation }\end{array}$ & $\begin{array}{l}\text { Total } \\
\text { Infill }\end{array}$ & $\begin{array}{l}\text { Total } \\
\text { Runoff }\end{array}$ & $\begin{array}{l}\text { Total } \\
\text { Runoff }\end{array}$ & $\begin{array}{l}\text { Peak } \\
\text { Runoff }\end{array}$ & Runoff \\
\hline Subcatchment & $\mathrm{mm}$ & $\mathrm{mm}$ & $\mathrm{mm}$ & $10^{\wedge} \sigma \mathrm{ltr}$ & CMS & Coeff \\
\hline S1 & 925.5 & 49.83 & 833.94 & 143880.2 & 35.28 & 0.901 \\
\hline S2 & 925.5 & 49.83 & 852.65 & 44338.22 & 14.47 & 0.921 \\
\hline S3 & 925.5 & 49.83 & 813.59 & 261268.1 & 54.34 & 0.879 \\
\hline S4 & 925.5 & 49.83 & 848.03 & 67001 & 19.94 & 0.916 \\
\hline S5 & 925.5 & 49.83 & 835 & 137887.8 & 34.2 & 0.902 \\
\hline S6 & 925.5 & 91.1 & 648.65 & 70300.82 & 24.53 & 0.701 \\
\hline S7 & 925.5 & 85.76 & 615.76 & 23097.44 & 10.69 & 0.665 \\
\hline S8 & 925.5 & 81.08 & 740.16 & 31580.38 & 14.73 & 0.8 \\
\hline S9 & 925.5 & 82.49 & 738.25 & 38765.62 & 16.51 & 0.798 \\
\hline S10 & 925.5 & 95.02 & 604.83 & 146040.2 & 38.66 & 0.654 \\
\hline S11a & 925.5 & 81.26 & 721.37 & 40453.9 & 17.5 & 0.779 \\
\hline S11b & 925.5 & 89.14 & 573.89 & 41042.29 & 14.72 & 0.62 \\
\hline S12a & 925.5 & 83.77 & 718.26 & 81706.83 & 30.9 & 0.776 \\
\hline $\mathrm{S} 12 \mathrm{~b}$ & 925.5 & 85.91 & 576.66 & 20284.62 & 8.64 & 0.623 \\
\hline S13 & 925.5 & 78.73 & 543.28 & 4647.77 & 2.56 & 0.587 \\
\hline S14 & 925.5 & 6.64 & 915.69 & 3049.27 & 1.68 & 0.989 \\
\hline S15 & 925.5 & 62.9 & 163.31 & 3266.22 & 1.74 & 0.176 \\
\hline S16 & 925.5 & 29.5 & 316.9 & 18239.25 & 8.45 & 0.342 \\
\hline S17 & 925.5 & 63.67 & 163.12 & 4044.05 & 2.1 & 0.176 \\
\hline S18 & 925.5 & 78.42 & 309.78 & 28610.79 & 8.91 & 0.335 \\
\hline S19 & 925.5 & 73.55 & 313.41 & 5846.72 & 2.69 & 0.339 \\
\hline S20 & 925.5 & 77.29 & 311.42 & 15293.14 & 5.66 & 0.336 \\
\hline S21 & 925.5 & 77.93 & 310.77 & 20076.58 & 6.91 & 0.336 \\
\hline $\mathrm{S} 22$ & 925.5 & 78.26 & 310.17 & 25057.44 & 8.1 & 0.335 \\
\hline S23 & 925.5 & 66.45 & 821.57 & 57510.02 & 11.94 & 0.888 \\
\hline S24 & 925.5 & 78.55 & 309.35 & 32605.39 & 9.77 & 0.334 \\
\hline
\end{tabular}


Table 15.33 Case 8 SWMM Results

\begin{tabular}{|c|c|c|c|c|c|c|}
\hline & $\begin{array}{c}\text { Total } \\
\text { Percipitation }\end{array}$ & $\begin{array}{l}\text { Total } \\
\text { Infill }\end{array}$ & $\begin{array}{l}\text { Total } \\
\text { Runoff }\end{array}$ & $\begin{array}{l}\text { Total } \\
\text { Runoff }\end{array}$ & $\begin{array}{l}\text { Peak } \\
\text { Runoff }\end{array}$ & Runoff \\
\hline Subcatchment & $\mathrm{mm}$ & $\mathrm{mm}$ & $\mathrm{mm}$ & $10^{\wedge} \sigma \mathrm{ltr}$ & CMS & Coeff \\
\hline S1 & 925.5 & 49.83 & 833.94 & 143880.2 & 35.28 & 0.901 \\
\hline S2 & 925.5 & 49.83 & 852.65 & 44338.22 & 14.47 & 0.921 \\
\hline S3 & 925.5 & 49.83 & 813.59 & 261268.1 & 54.34 & 0.879 \\
\hline S4 & 925.5 & 49.83 & 848.03 & 67001 & 19.94 & 0.916 \\
\hline S5 & 925.5 & 49.83 & 835 & 137887.8 & 34.2 & 0.902 \\
\hline S6 & 925.5 & 84.89 & 752.71 & 81579.2 & 30.67 & 0.813 \\
\hline S7 & 925.5 & 85.76 & 615.76 & 23097.44 & 10.69 & 0.665 \\
\hline S8 & 925.5 & 81.08 & 740.16 & 31580.38 & 14.73 & 0.8 \\
\hline S9 & 925.5 & 82.49 & 738.25 & 38765.62 & 16.51 & 0.798 \\
\hline S10 & 925.5 & 95.02 & 604.83 & 146040.2 & 38.66 & 0.654 \\
\hline S11a & 925.5 & 43.28 & 869.64 & 48768.61 & 21.96 & 0.94 \\
\hline S11b & 925.5 & 89.14 & 573.89 & 41042.29 & 14.72 & 0.62 \\
\hline S12a & 925.5 & 43.28 & 866.53 & 98573.79 & 39.79 & 0.936 \\
\hline $\mathrm{S} 12 \mathrm{~b}$ & 925.5 & 85.91 & 576.66 & 20284.62 & 8.64 & 0.623 \\
\hline S13 & 925.5 & 78.73 & 543.28 & 4647.77 & 2.56 & 0.587 \\
\hline S14 & 925.5 & 6.64 & 915.69 & 3049.27 & 1.68 & 0.989 \\
\hline S15 & 925.5 & 62.9 & 163.31 & 3266.22 & 1.74 & 0.176 \\
\hline S16 & 925.5 & 29.5 & 316.9 & 18239.25 & 8.45 & 0.342 \\
\hline S17 & 925.5 & 63.67 & 163.12 & 4044.05 & 2.1 & 0.176 \\
\hline S18 & 925.5 & 78.42 & 309.78 & 28610.79 & 8.91 & 0.335 \\
\hline S19 & 925.5 & 73.55 & 313.41 & 5846.72 & 2.69 & 0.339 \\
\hline S20 & 925.5 & 77.29 & 311.42 & 15293.14 & 5.66 & 0.336 \\
\hline S21 & 925.5 & 77.93 & 310.77 & 20076.58 & 6.91 & 0.336 \\
\hline S22 & 925.5 & 78.26 & 310.17 & 25057.44 & 8.1 & 0.335 \\
\hline S23 & 925.5 & 66.45 & 821.57 & 57510.02 & 11.94 & 0.888 \\
\hline S24 & 925.5 & 19.93 & 889.01 & 93700.42 & 33.93 & 0.961 \\
\hline
\end{tabular}


Table 15.34 Case 9 SWMM Results

\begin{tabular}{|c|c|c|c|c|c|c|}
\hline & $\begin{array}{l}\text { Total } \\
\text { Percipitation }\end{array}$ & $\begin{array}{l}\text { Total } \\
\text { Infill }\end{array}$ & $\begin{array}{l}\text { Total } \\
\text { Runoff }\end{array}$ & $\begin{array}{l}\text { Total } \\
\text { Runoff }\end{array}$ & $\begin{array}{l}\text { Peak } \\
\text { Runoff }\end{array}$ & Runoff \\
\hline Subcatchment & $\mathrm{mm}$ & $\mathrm{mm}$ & $\mathrm{mm}$ & $10^{\wedge} \sigma \mathrm{ltr}$ & CMS & Coeff \\
\hline S1 & 925.5 & 49.83 & 833.94 & 143880.2 & 35.28 & 0.901 \\
\hline S2 & 925.5 & 49.83 & 852.65 & 44338.22 & 14.47 & 0.921 \\
\hline S3 & 925.5 & 49.83 & 813.59 & 261268.1 & 54.34 & 0.879 \\
\hline S4 & 925.5 & 49.83 & 848.03 & 67001 & 19.94 & 0.916 \\
\hline S5 & 925.5 & 92.76 & 728.38 & 120281.2 & 26.48 & 0.787 \\
\hline S6 & 925.5 & 84.89 & 752.7 & 81578.25 & 30.67 & 0.813 \\
\hline S7 & 925.5 & 46.51 & 868.05 & 32560.62 & 15.81 & 0.938 \\
\hline S8 & 925.5 & 81.08 & 740.15 & 31580 & 14.73 & 0.8 \\
\hline S9 & 925.5 & 82.49 & 738.24 & 38765.13 & 16.51 & 0.798 \\
\hline S10 & 925.5 & 95.72 & 641.29 & 154844.4 & 39.78 & 0.693 \\
\hline S11a & 925.5 & 81.26 & 721.36 & 40453.33 & 17.5 & 0.779 \\
\hline S11b & 925.5 & 89.14 & 573.88 & 41041.34 & 14.72 & 0.62 \\
\hline S12a & 925.5 & 83.77 & 718.25 & 81705.63 & 30.9 & 0.776 \\
\hline $\mathrm{S} 12 \mathrm{~b}$ & 925.5 & 85.91 & 576.64 & 20284.18 & 8.64 & 0.623 \\
\hline S13 & 925.5 & 78.73 & 543.27 & 4647.67 & 2.56 & 0.587 \\
\hline S14 & 925.5 & 6.64 & 915.69 & 3049.27 & 1.68 & 0.989 \\
\hline S15 & 925.5 & 62.9 & 163.29 & 3265.86 & 1.74 & 0.176 \\
\hline S16 & 925.5 & 29.5 & 316.9 & 18239.06 & 8.45 & 0.342 \\
\hline S17 & 925.5 & 63.67 & 163.1 & 4043.58 & 2.1 & 0.176 \\
\hline S18 & 925.5 & 78.42 & 309.76 & 28608.94 & 8.91 & 0.335 \\
\hline S19 & 925.5 & 73.55 & 313.39 & 5846.4 & 2.69 & 0.339 \\
\hline S20 & 925.5 & 77.29 & 311.4 & 15292.21 & 5.66 & 0.336 \\
\hline S21 & 925.5 & 77.93 & 310.75 & 20075.32 & 6.91 & 0.336 \\
\hline S22 & 925.5 & 78.26 & 310.15 & 25055.83 & 8.1 & 0.335 \\
\hline S23 & 925.5 & 66.45 & 821.57 & 57510.02 & 11.94 & 0.888 \\
\hline S24 & 925.5 & 19.93 & 889.01 & 93700.42 & 33.93 & 0.961 \\
\hline
\end{tabular}


Table 15.35 Case 10 SWMM Results

\begin{tabular}{|c|c|c|c|c|c|c|}
\hline & $\begin{array}{c}\text { Total } \\
\text { Percipitation }\end{array}$ & $\begin{array}{l}\text { Total } \\
\text { Inffll }\end{array}$ & $\begin{array}{l}\text { Total } \\
\text { Runoff }\end{array}$ & $\begin{array}{l}\text { Total } \\
\text { Runoff }\end{array}$ & $\begin{array}{l}\text { Peak } \\
\text { Runoff }\end{array}$ & Runoff \\
\hline Subcatchment & $\mathrm{mm}$ & $\mathrm{mm}$ & $\mathrm{mm}$ & $10^{\wedge} 6 \mathrm{ltr}$ & CMS & Coeff \\
\hline S1 & 925.5 & 100.94 & 623.92 & 107645.2 & 19.33 & 0.674 \\
\hline S2 & 925.5 & 95.35 & 642.05 & 33386.76 & 8.79 & 0.694 \\
\hline S3 & 925.5 & 49.83 & 813.59 & 261268.1 & 54.34 & 0.879 \\
\hline S4 & 925.5 & 89.71 & 741.35 & 58572.39 & 15.78 & 0.801 \\
\hline S5 & 925.5 & 92.76 & 728.39 & 120282.9 & 26.48 & 0.787 \\
\hline S6 & 925.5 & 84.89 & 752.71 & 81579.2 & 30.67 & 0.813 \\
\hline S7 & 925.5 & 85.76 & 615.76 & 23097.44 & 10.69 & 0.665 \\
\hline S8 & 925.5 & 81.08 & 740.16 & 31580.38 & 14.73 & 0.8 \\
\hline S9 & 925.5 & 82.49 & 738.25 & 38765.62 & 16.51 & 0.798 \\
\hline S10 & 925.5 & 95.02 & 604.83 & 146040.2 & 38.66 & 0.654 \\
\hline S11a & 925.5 & 81.26 & 721.37 & 40453.9 & 17.5 & 0.779 \\
\hline S11b & 925.5 & 82.94 & 719.34 & 51444.06 & 20.34 & 0.777 \\
\hline S12a & 925.5 & 83.77 & 718.26 & 81706.84 & 30.9 & 0.776 \\
\hline $\mathrm{S} 12 \mathrm{~b}$ & 925.5 & 85.91 & 576.66 & 20284.62 & 8.64 & 0.623 \\
\hline S13 & 925.5 & 78.73 & 543.28 & 4647.77 & 2.56 & 0.587 \\
\hline S14 & 925.5 & 6.64 & 915.69 & 3049.27 & 1.68 & 0.989 \\
\hline S15 & 925.5 & 62.9 & 163.31 & 3266.22 & 1.74 & 0.176 \\
\hline S16 & 925.5 & 29.5 & 316.9 & 18239.25 & 8.45 & 0.342 \\
\hline S17 & 925.5 & 63.67 & 163.12 & 4044.05 & 2.1 & 0.176 \\
\hline S18 & 925.5 & 78.42 & 309.78 & 28610.79 & 8.91 & 0.335 \\
\hline S19 & 925.5 & 73.55 & 313.41 & 5846.72 & 2.69 & 0.339 \\
\hline S20 & 925.5 & 77.29 & 311.42 & 15293.14 & 5.66 & 0.336 \\
\hline S21 & 925.5 & 77.93 & 310.77 & 20076.58 & 6.91 & 0.336 \\
\hline S22 & 925.5 & 78.26 & 310.17 & 25057.44 & 8.1 & 0.335 \\
\hline S23 & 925.5 & 66.45 & 821.57 & 57510.02 & 11.94 & 0.888 \\
\hline S24 & 925.5 & 19.93 & 889.01 & 93700.42 & 33.93 & 0.961 \\
\hline
\end{tabular}


15.7 Appendix G: Tables of Capital and Maintenance Cost

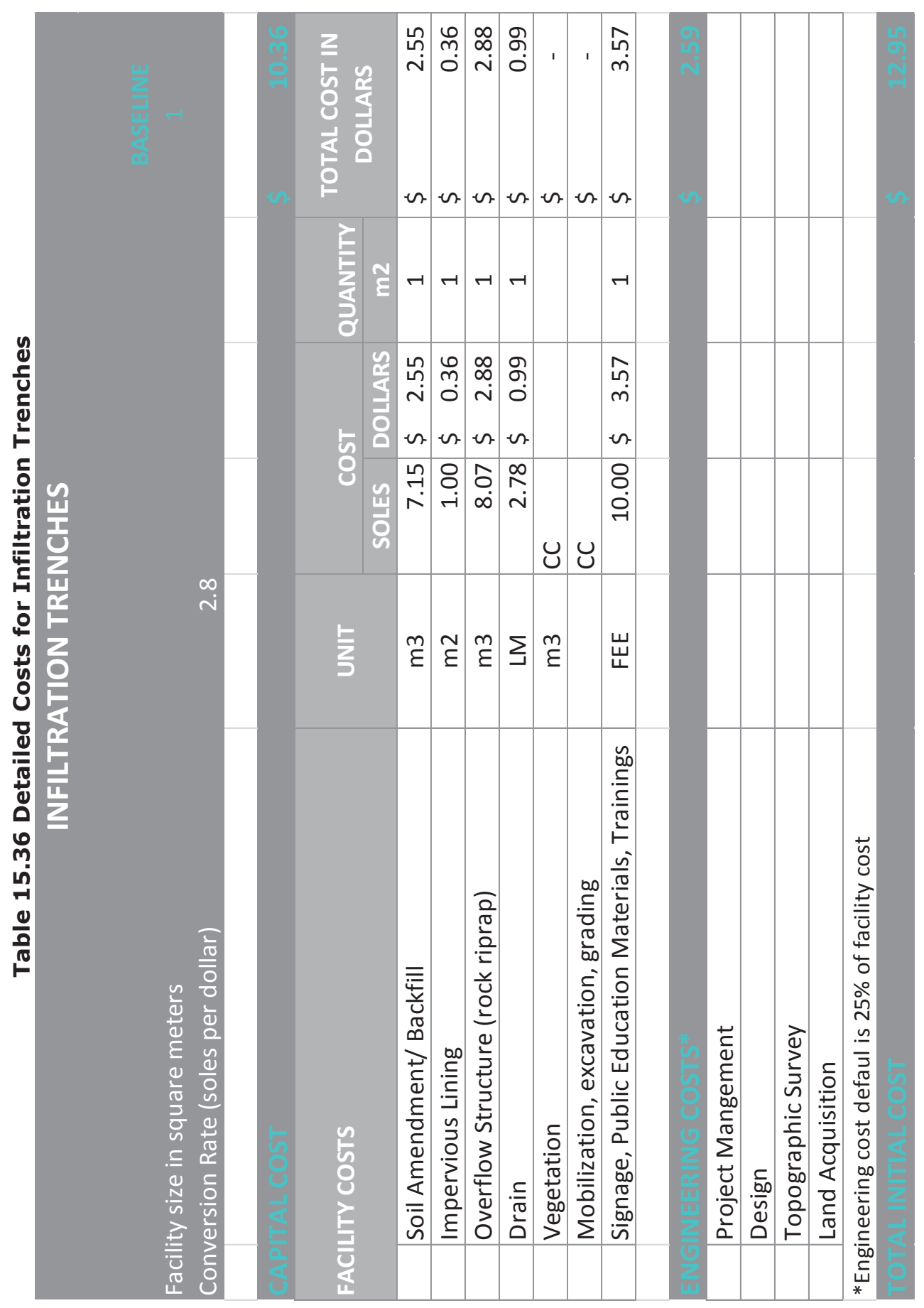




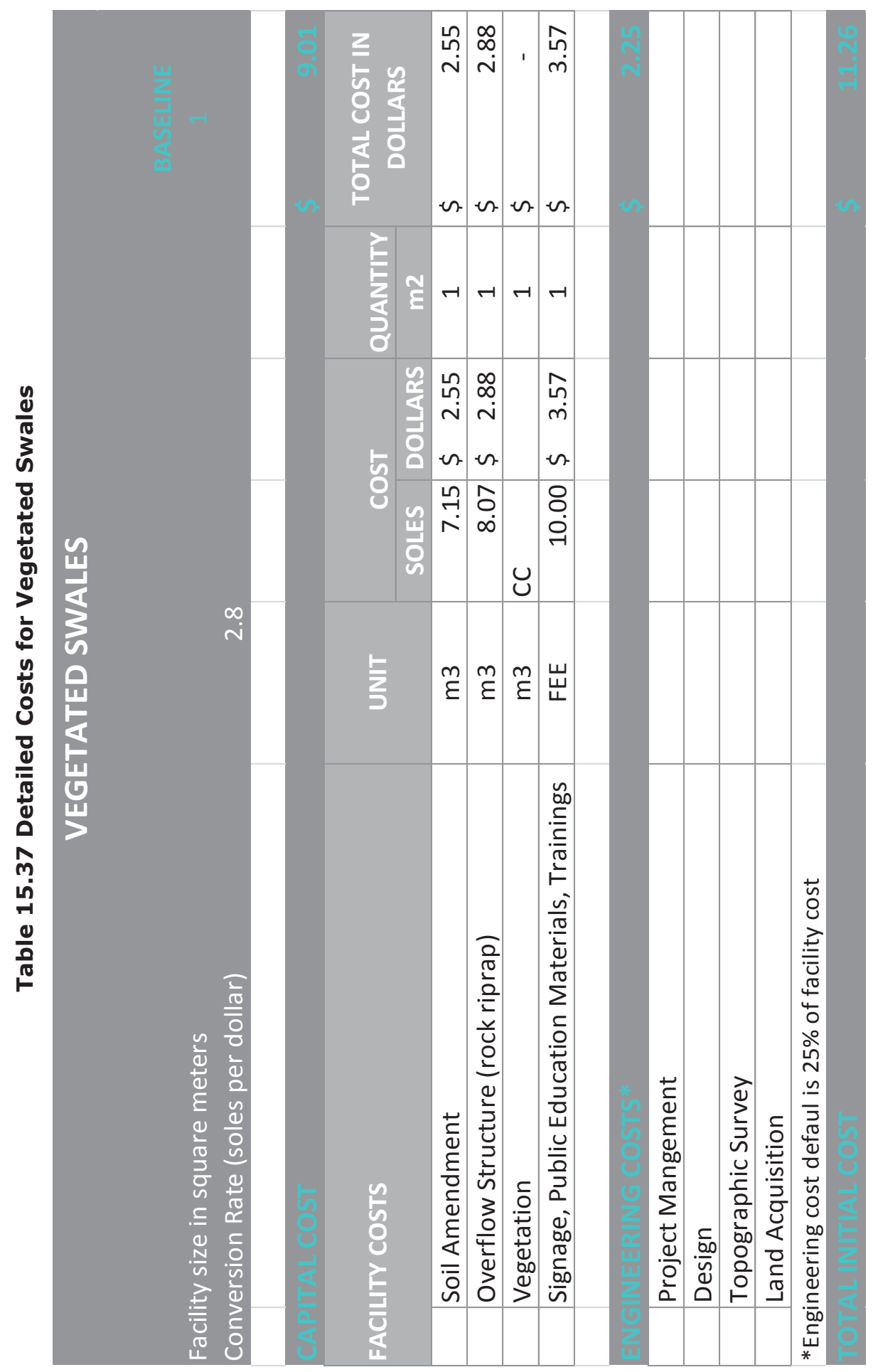




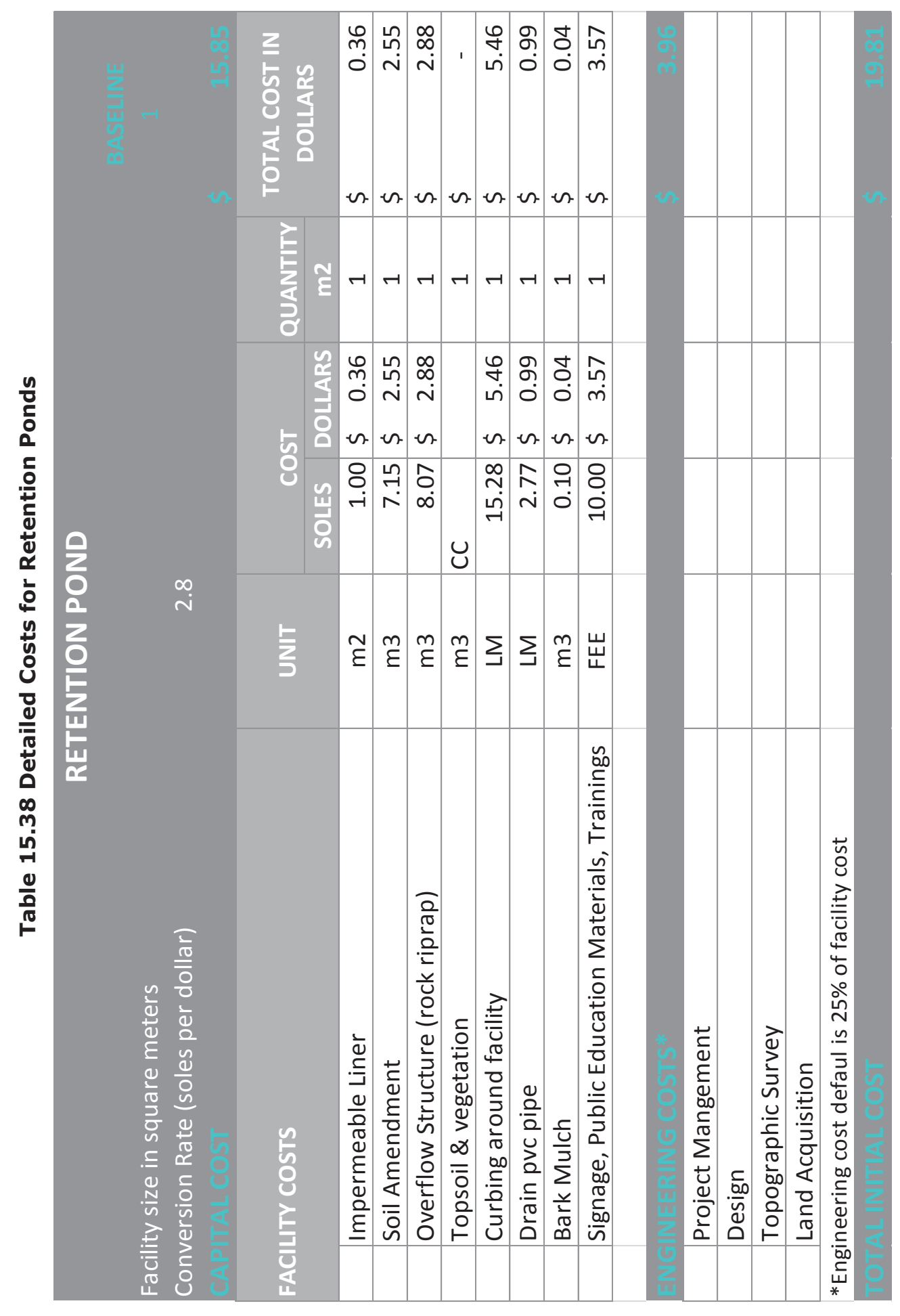




\subsection{Appendix H: Total Cost of LID BMPs by Case}

Table 15.39 Case 1 Total Cost by Subcatchment

\begin{tabular}{|c|c|c|c|c|c|}
\hline SUBCATCHMENT & LID BMPs & $\begin{array}{c}\text { INITIAL } \\
\text { FACILITY COST }\end{array}$ & \multicolumn{2}{|c|}{$\begin{array}{l}\text { MAINTENANCE } \\
\text { COST } \\
\text { OVER } 10 \text { YRS. }\end{array}$} & TOTAL COST \\
\hline$S 12 b$ & Infiltration trench & $4,554.34$ & $\$$ & $7,787.97$ & $\$ 12,342.31$ \\
\hline S13 & Infiltration trench & $1,107.64$ & $\$$ & $1,894.08$ & $\$ 3,001.72$ \\
\hline S16 & Infiltration trench & $7,451.81$ & $\$$ & $12,742.68$ & $\$ 20,194.49$ \\
\hline S18 & Infiltration trench & $\$ 11,957.99$ & $\$$ & $20,448.28$ & $\$ 32,406.27$ \\
\hline S21 & Infiltration trench & $8,364.34$ & $\$$ & $14,303.10$ & $\$ 22,667.44$ \\
\hline \multirow[t]{4}{*}{ S23 } & Retention Pond & $\$ 10,399.67$ & $\$$ & $28,145.25$ & $\$ 38,544.92$ \\
\hline & & \multicolumn{3}{|c|}{ INITIAL COST FOR CASE 1} & $\$ 43,835.79$ \\
\hline & \multicolumn{4}{|c|}{ MAINTENANCE COST OVER 10 YRS. FOR CASE 1} & $\$ 85,321.36$ \\
\hline & & \multicolumn{3}{|c|}{ TOTAL COST FOR CASE 1} & $\$ 129,157.15$ \\
\hline
\end{tabular}

Table 15.40 Case c Total Cost by Subcatchment

\begin{tabular}{|c|c|c|c|c|}
\hline SUBCATCHMENT & LID BMPs & $\begin{array}{c}\text { CAPITAL } \\
\text { FACILITY COST }\end{array}$ & $\begin{array}{c}\text { MAINTENANCE } \\
\text { COST } \\
\text { OVER } 10 \text { YRS. }\end{array}$ & TOTAL COST \\
\hline $\mathrm{S} 12 \mathrm{~b}$ & Infiltration trench & $4,554.34$ & $7,787.97$ & $\$ 12,342.31$ \\
\hline S13 & Infiltration trench & $1,107.64$ & $1,894.08$ & $\$ \quad 3,001.72$ \\
\hline S16 & Infiltration trench & $7,451.81$ & $12,742.68$ & $\$ 20,194.49$ \\
\hline S18 & Infiltration trench & $\$ 11,957.99$ & $20,448.28$ & $\$ 32,406.27$ \\
\hline S19 & Vegetative Swale & $3,386.68$ & $6,658.61$ & $\$ 10,045.29$ \\
\hline S20 & Vegetative Swale & $4,896.75$ & $9,627.58$ & $\$ 14,524.33$ \\
\hline S21 & Infiltration trench & $8,364.34$ & $14,303.10$ & $\$ 22,667.44$ \\
\hline S22 & Vegetative Swale & $6,187.24$ & $12,164.82$ & $\$ 18,352.06$ \\
\hline S23 & Bioretention Pond & $\$ 10,399.67$ & $28,145.25$ & $\$ 38,544.92$ \\
\hline \multirow[t]{4}{*}{ S24 } & Vegetative Swale & $7,047.84$ & $13,856.87$ & $\$ 20,904.71$ \\
\hline & \multicolumn{3}{|c|}{ CAPITAL FACILITY COST FOR CASE 2} & $\$ 65,354.30$ \\
\hline & \multicolumn{3}{|c|}{ MAINTENANCE COST OVER 10 YRS. FOR CASE 2} & $\$ 127,629.24$ \\
\hline & & \multicolumn{2}{|c|}{ TOTAL COST FOR CASE 2} & $\$ 192,983.54$ \\
\hline
\end{tabular}


Table 15.41 Case 3 Total Cost by Subcatchment

\begin{tabular}{|c|c|c|c|c|}
\hline SUBCATCHMENT & LID BMPs & $\begin{array}{c}\text { CAPITAL } \\
\text { FACILITY COST }\end{array}$ & $\begin{array}{c}\text { MAINTENANCE } \\
\text { COST } \\
\text { OVER } 10 \text { YRS. }\end{array}$ & TOTAL COST \\
\hline S11a & Bioretention Pond & $8,331.42$ & $22,547.83$ & $\$ 30,879.25$ \\
\hline S11a & Infiltration Trench & $7,260.71$ & $12,415.89$ & $\$ 19,676.60$ \\
\hline S12a & Bioretention Pond & $\$ 16,900.36$ & $45,738.44$ & $\$ 62,638.80$ \\
\hline S12a & Infiltration Trench & $\$ \quad 14,728.32$ & $25,185.58$ & $\$ 39,913.90$ \\
\hline S12b & Infiltration Trench & $4,554.34$ & $7,787.97$ & $\$ 12,342.31$ \\
\hline S13 & Infiltration Trench & $1,107.64$ & $1,894.08$ & $\$ \quad 3,001.72$ \\
\hline S16 & Infiltration Trench & $7,451.81$ & $12,742.68$ & $\$ 20,194.49$ \\
\hline S18 & Infiltration Trench & $11,957.99$ & $20,448.28$ & $\$ 32,406.27$ \\
\hline S19 & Vegetative Swale & $3,386.68$ & $6,658.61$ & $\$ 10,045.29$ \\
\hline S20 & Vegetative Swale & $4,896.75$ & $9,627.58$ & $\$ 14,524.33$ \\
\hline S21 & Infiltration Trench & $8,364.34$ & $14,303.10$ & $\$ 22,667.44$ \\
\hline$S 22$ & Vegetative Swale & $6,187.24$ & $12,164.82$ & $\$ 18,352.06$ \\
\hline$S 23$ & Bioretention Pond & $\$ \quad 10,399.67$ & $28,145.25$ & $\$ 38,544.92$ \\
\hline \multirow[t]{4}{*}{ S24 } & Vegetative Swale & $7,047.84$ & $13,856.87$ & $\$ 20,904.71$ \\
\hline & \multicolumn{3}{|c|}{ CAPITAL FACILITY COST FOR Case 3} & $\$ 112,575.11$ \\
\hline & \multicolumn{3}{|c|}{ MAINTENANCE COST OVER 10 YRS. FOR Case 3} & $\$ 233,516.98$ \\
\hline & & \multicolumn{2}{|c|}{ TOTAL COST FOR Case 3} & $\$ 346,092.09$ \\
\hline
\end{tabular}


Table 15.42 Case 4 Total Cost by Subcatchment

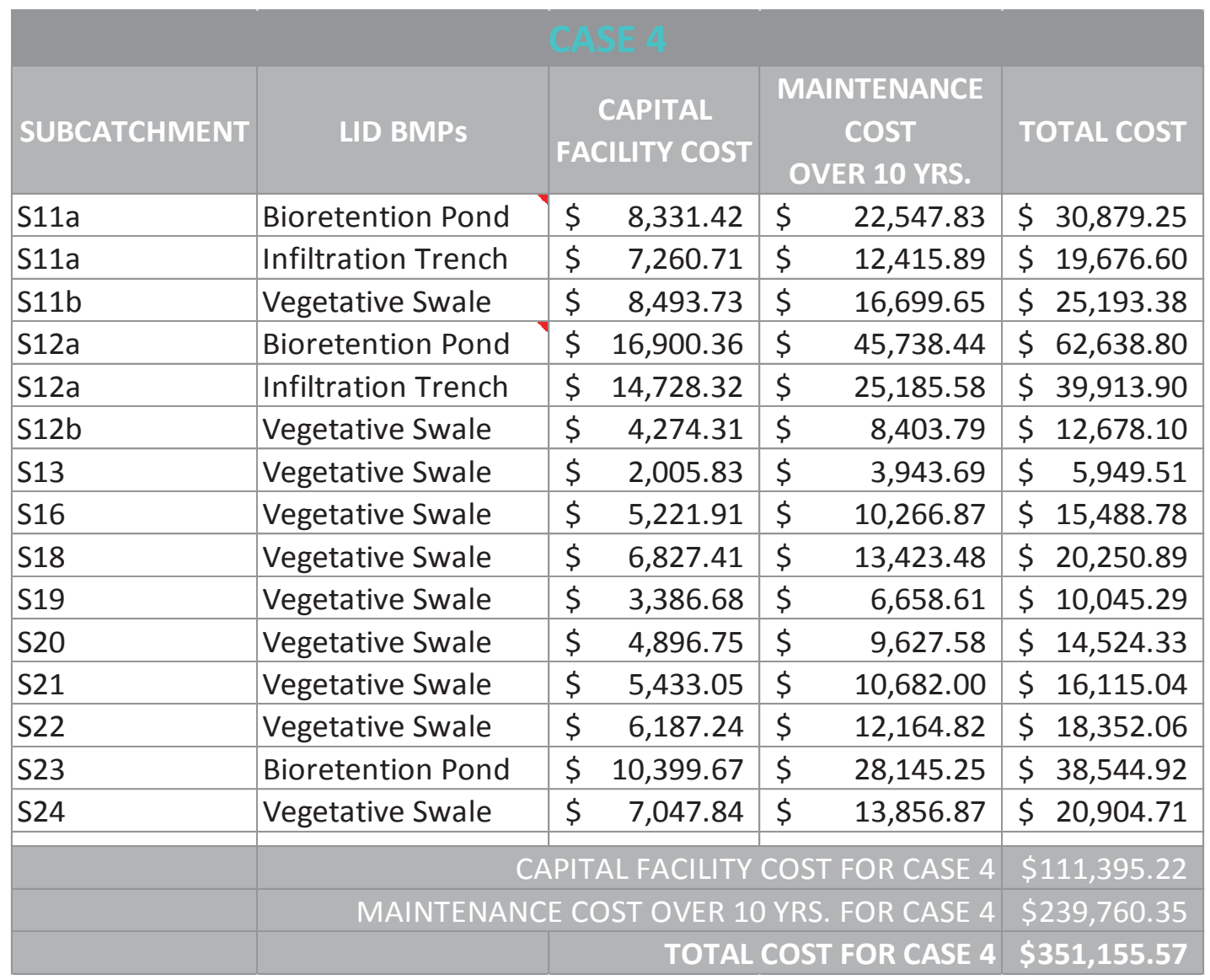


Table 15.43 Case 5 Total Cost by Subcatchment

\begin{tabular}{|c|c|c|c|c|}
\hline SUBCATCHMENT & LID BMPs & $\begin{array}{c}\text { CAPITAL } \\
\text { FACILITY COST }\end{array}$ & $\begin{array}{c}\text { MAINTENANCE } \\
\text { COST } \\
\text { OVER } 10 \text { YRS. }\end{array}$ & TOTAL COST \\
\hline S6 & Infiltration Trench & $\$ 14,032.27$ & $23,995.33$ & $\$ 38,027.61$ \\
\hline S7 & Infiltration Trench & $\$ \quad 4,857.56$ & $8,306.49$ & $\$ 13,164.05$ \\
\hline S8 & Bioretention Pond & $6,338.85$ & $17,155.20$ & $\$ 23,494.05$ \\
\hline S8 & Infiltration Trench & $5,524.22$ & $9,446.47$ & $\$ 14,970.69$ \\
\hline S9 & Bioretention Pond & $7,801.34$ & $21,113.23$ & $\$ 28,914.56$ \\
\hline S9 & Infiltration Trench & $6,798.62$ & $11,625.71$ & $\$ 18,424.34$ \\
\hline S10 & Infiltration Trench & $\$ 31,262.01$ & $53,458.36$ & $\$ 84,720.37$ \\
\hline S11a & Bioretention Pond & $8,331.42$ & $22,547.83$ & $\$ 30,879.25$ \\
\hline S11a & Infiltration Trench & $7,260.71$ & $12,415.89$ & $\$ 19,676.60$ \\
\hline S11b & Vegetative Swale & $8,493.73$ & $16,699.65$ & $\$ 25,193.38$ \\
\hline S12a & Bioretention Pond & $\$ 16,900.36$ & $45,738.44$ & $\$ 62,638.80$ \\
\hline S12a & Infiltration Trench & $\$ \quad 14,728.32$ & $25,185.58$ & $\$ 39,913.90$ \\
\hline $\mathrm{S} 12 \mathrm{~b}$ & Vegetative Swale & $\$ \quad 4,274.31$ & $8,403.79$ & $\$ 12,678.10$ \\
\hline S13 & Vegetative Swale & $2,005.83$ & $3,943.69$ & $\$ \quad 5,949.51$ \\
\hline S16 & Vegetative Swale & $5,221.91$ & $10,266.87$ & $\$ 15,488.78$ \\
\hline S18 & Vegetative Swale & $6,827.41$ & $13,423.48$ & $\$ 20,250.89$ \\
\hline S19 & Vegetative Swale & $3,386.68$ & $6,658.61$ & $\$ 10,045.29$ \\
\hline S20 & Vegetative Swale & $4,896.75$ & $9,627.58$ & $\$ 14,524.33$ \\
\hline S21 & Vegetative Swale & $5,433.05$ & $10,682.00$ & $\$ 16,115.04$ \\
\hline S22 & Vegetative Swale & $6,187.24$ & $12,164.82$ & $\$ 18,352.06$ \\
\hline S23 & Bioretention Pond & $\$ 10,399.67$ & $28,145.25$ & $\$ 38,544.92$ \\
\hline \multirow[t]{4}{*}{ S24 } & Vegetative Swale & $\$ \quad 7,047.84$ & $13,856.87$ & $\$ 20,904.71$ \\
\hline & \multicolumn{3}{|c|}{ CAPITAL FACILITY COST FOR CASE 5} & $\$ 188,010.10$ \\
\hline & \multicolumn{3}{|c|}{ MAINTENANCE COST OVER 10 YRS. FOR CASE 5} & $\$ 384,861.14$ \\
\hline & & \multicolumn{2}{|c|}{ TOTAL COST FOR CASE 5} & $\$ 572,871.24$ \\
\hline
\end{tabular}


Table 15.44 Case 6 Total Cost by Subcatchment

\begin{tabular}{|c|c|c|c|c|}
\hline SUBCATCHMENT & LID BMPs & $\begin{array}{c}\text { CAPITAL } \\
\text { FACILITY COST }\end{array}$ & $\begin{array}{c}\text { MAINTENANCE } \\
\text { COST } \\
\text { OVER } 10 \text { YRS. }\end{array}$ & TOTAL COST \\
\hline S6 & Vegetative Swale & $9,242.85$ & $18,172.51$ & $\$ 27,415.36$ \\
\hline S7 & Vegetative Swale & $4,361.30$ & $8,574.82$ & $\$ 12,936.12$ \\
\hline$S 8$ & Bioretention Pond & $6,338.85$ & $17,155.20$ & $\$ 23,494.05$ \\
\hline S8 & Vegetative Swale & $6,492.12$ & $12,764.26$ & $\$ 19,256.39$ \\
\hline S9 & Bioretention Pond & $7,801.34$ & $21,113.23$ & $\$ 28,914.56$ \\
\hline S9 & Vegetative Swale & $5,372.24$ & $10,562.44$ & $\$ 15,934.68$ \\
\hline S10 & Vegetative Swale & $\$ \quad 12,236.81$ & $24,058.98$ & $\$ 36,295.80$ \\
\hline S11a & Bioretention Pond & $\$ \quad 8,331.42$ & $22,547.83$ & $\$ 30,879.25$ \\
\hline S11a & Infiltration Trench & $7,260.71$ & $12,415.89$ & $\$ 19,676.60$ \\
\hline S11b & Vegetative Swale & $8,493.73$ & $16,699.65$ & $\$ 25,193.38$ \\
\hline S12a & Bioretention Pond & $\$ 16,900.36$ & $45,738.44$ & $\$ 62,638.80$ \\
\hline S12a & Infiltration Trench & $\$ 14,728.32$ & $25,185.58$ & $\$ 39,913.90$ \\
\hline $\mathrm{S} 12 \mathrm{~b}$ & Vegetative Swale & $4,274.31$ & $8,403.79$ & $\$ 12,678.10$ \\
\hline S13 & Vegetative Swale & $2,005.83$ & $3,943.69$ & $\$ \quad 5,949.51$ \\
\hline S16 & Vegetative Swale & $5,221.91$ & $10,266.87$ & $\$ 15,488.78$ \\
\hline S18 & Vegetative Swale & $6,827.41$ & $13,423.48$ & $\$ 20,250.89$ \\
\hline S19 & Vegetative Swale & $3,386.68$ & $6,658.61$ & $\$ 10,045.29$ \\
\hline S20 & Vegetative Swale & $4,896.75$ & $9,627.58$ & $\$ 14,524.33$ \\
\hline S21 & Vegetative Swale & $5,433.05$ & $10,682.00$ & $\$ 16,115.04$ \\
\hline S22 & Vegetative Swale & $6,187.24$ & $12,164.82$ & $\$ 18,352.06$ \\
\hline S23 & Bioretention Pond & $\$ 10,399.67$ & $28,145.25$ & $\$ 38,544.92$ \\
\hline \multirow[t]{4}{*}{ S24 } & Vegetative Swale & $7,047.84$ & $13,856.87$ & $\$ 20,904.71$ \\
\hline & \multicolumn{3}{|c|}{ CAPITAL FACILITY COST FOR CASE 6} & $\$ 163,240.73$ \\
\hline & \multicolumn{3}{|c|}{ MAINTENANCE COST OVER 10 YRS. FOR CASE 6} & $\$ 352,161.80$ \\
\hline & & \multicolumn{2}{|c|}{ TOTAL COST FOR CASE 6} & $\$ 515,402.53$ \\
\hline
\end{tabular}


Table 15.45 Case 7 Total Cost by Subcatchment

\begin{tabular}{|c|c|c|c|c|}
\hline SUBCATCHMENT & LID BMPs & $\begin{array}{c}\text { CAPITAL } \\
\text { FACILITY COST }\end{array}$ & $\begin{array}{c}\text { MAINTENANCE } \\
\text { COST } \\
\text { OVER } 10 \text { YRS. }\end{array}$ & TOTAL COST \\
\hline S6 & Infiltration Trench & $\$ 14,032.27$ & $23,995.33$ & $\$ 38,027.61$ \\
\hline S7 & Infiltration Trench & $4,857.56$ & $8,306.49$ & $\$ 13,164.05$ \\
\hline S8 & Bioretention Pond & $6,338.85$ & $17,155.20$ & $\$ 23,494.05$ \\
\hline S8 & Infiltration Trench & $5,524.22$ & $9,446.47$ & $\$ 14,970.69$ \\
\hline S9 & Bioretention Pond & $7,801.34$ & $21,113.23$ & $\$ 28,914.56$ \\
\hline S9 & Infiltration Trench & $6,798.62$ & $11,625.71$ & $\$ 18,424.34$ \\
\hline S10 & Infiltration Trench & $\$ 31,262.01$ & $31,262.01$ & $\$ 62,524.02$ \\
\hline S11a & Bioretention Pond & $8,331.42$ & $22,547.83$ & $\$ 30,879.25$ \\
\hline S11a & Infiltration Trench & $7,260.71$ & $12,415.89$ & $\$ 19,676.60$ \\
\hline S11b & Infiltration Trench & $9,259.25$ & $15,833.42$ & $\$ 25,092.68$ \\
\hline S12a & Bioretention Pond & $\$ 16,900.36$ & $45,738.44$ & $\$ 62,638.80$ \\
\hline S12a & Infiltration Trench & $\$ 14,728.32$ & $25,185.58$ & $\$ 39,913.90$ \\
\hline$S 12 b$ & Infiltration Trench & $4,554.34$ & $7,787.97$ & $\$ 12,342.31$ \\
\hline S13 & Infiltration Trench & $1,107.64$ & $1,894.08$ & $\$ \quad 3,001.72$ \\
\hline S15 & Infiltration Trench & $2,589.46$ & $4,428.00$ & $\$ 7,017.46$ \\
\hline S16 & Infiltration Trench & $7,451.81$ & $12,742.68$ & $\$ 20,194.49$ \\
\hline S17 & Infiltration Trench & $3,209.89$ & $5,488.95$ & $\$ \quad 8,698.84$ \\
\hline S18 & Infiltration Trench & $\$ 11,957.99$ & $20,448.28$ & $\$ 32,406.27$ \\
\hline S19 & Infiltration Trench & $2,415.32$ & $4,130.22$ & $\$ \quad 6,545.53$ \\
\hline S20 & Infiltration Trench & $6,358.16$ & $10,872.51$ & $\$ 17,230.67$ \\
\hline S21 & Infiltration Trench & $8,364.34$ & $14,303.10$ & $\$ 22,667.44$ \\
\hline S22 & Infiltration Trench & $\$ \quad 10,459.47$ & $17,885.80$ & $\$ 28,345.27$ \\
\hline S23 & Bioretention Pond & $\$ 10,399.67$ & $28,145.25$ & $\$ 38,544.92$ \\
\hline \multirow[t]{4}{*}{ S24 } & Infiltration Trench & $\$ 13,646.19$ & $23,335.12$ & $\$ 36,981.30$ \\
\hline & \multicolumn{3}{|c|}{ CAPITAL FACILITY COST FOR CASE 7} & $\$ 215,609.21$ \\
\hline & \multicolumn{3}{|c|}{ MAINTENANCE COST OVER 10 YRS. FOR CASE 7} & $\$ 396,087.55$ \\
\hline & & \multicolumn{2}{|c|}{ TOTAL COST FOR CASE 7} & $\$ 611,696.76$ \\
\hline
\end{tabular}


Table 15.46 Case 8 Total Cost by Subcatchment

\begin{tabular}{|c|c|c|c|c|}
\hline SUBCATCHMENT & LID BMPs & $\begin{array}{c}\text { CAPITAL } \\
\text { FACILITY COST }\end{array}$ & $\begin{array}{c}\text { MAINTENANCE } \\
\text { COST } \\
\text { OVER } 10 \text { YRS. }\end{array}$ & TOTAL COST \\
\hline S6 & Infiltration Trench & $\$ 14,032.27$ & $23,995.33$ & $\$ 38,027.61$ \\
\hline S6 & Bioretention Pond & $\$ 16,101.66$ & $43,576.89$ & $\$ 59,678.55$ \\
\hline S7 & Infiltration Trench & $4,857.56$ & $8,306.49$ & $\$ 13,164.05$ \\
\hline S8 & Bioretention Pond & $6,338.85$ & $17,155.20$ & $\$ 23,494.05$ \\
\hline S8 & Infiltration Trench & $5,524.22$ & $9,446.47$ & $\$ 14,970.69$ \\
\hline S9 & Bioretention Pond & $7,801.34$ & $21,113.23$ & $\$ 28,914.56$ \\
\hline S9 & Infiltration Trench & $6,798.62$ & $11,625.71$ & $\$ 18,424.34$ \\
\hline S10 & Infiltration Trench & $\$ \quad 31,262.01$ & $31,262.01$ & $\$ 62,524.02$ \\
\hline S11a & Bioretention Pond & $8,331.42$ & $22,547.83$ & $\$ 30,879.25$ \\
\hline S11a & Vegetative Swale & $5,553.82$ & $15,695.05$ & $\$ 21,248.86$ \\
\hline S11b & Infiltration Trench & $9,259.25$ & $15,833.42$ & $\$ 25,092.68$ \\
\hline S12a & Bioretention Pond & $\$ 16,900.36$ & $45,738.44$ & $\$ 62,638.80$ \\
\hline S12a & Vegetative Swale & $7,982.77$ & $15,695.05$ & $\$ 23,677.81$ \\
\hline S12b & Infiltration Trench & $4,554.34$ & $7,787.97$ & $\$ 12,342.31$ \\
\hline S13 & Infiltration Trench & $1,107.64$ & $1,894.08$ & $\$ 3,001.72$ \\
\hline S15 & Infiltration Trench & $2,589.46$ & $4,428.00$ & $\$ 7,017.46$ \\
\hline S16 & Infiltration Trench & $7,451.81$ & $12,742.68$ & $\$ 20,194.49$ \\
\hline S17 & Infiltration Trench & $3,209.89$ & $5,488.95$ & $\$ \quad 8,698.84$ \\
\hline S18 & Infiltration Trench & $\$ 11,957.99$ & $20,448.28$ & $\$ 32,406.27$ \\
\hline S19 & Infiltration Trench & $2,415.32$ & $4,130.22$ & $\$ \quad 6,545.53$ \\
\hline S20 & Infiltration Trench & $6,358.16$ & $10,872.51$ & $\$ 17,230.67$ \\
\hline S21 & Infiltration Trench & $8,364.34$ & $14,303.10$ & $\$ 22,667.44$ \\
\hline S22 & Infiltration Trench & $\$ \quad 10,459.47$ & $17,885.80$ & $\$ 28,345.27$ \\
\hline S23 & Bioretention Pond & $\$ \quad 10,399.67$ & $28,145.25$ & $\$ 38,544.92$ \\
\hline \multirow[t]{4}{*}{ S24 } & Vegetative Swale & $7,047.84$ & $13,856.87$ & $\$ 20,904.71$ \\
\hline & \multicolumn{3}{|c|}{ CAPITAL FACILITY COST FOR CASE 8} & $\$ 216,660.08$ \\
\hline & \multicolumn{3}{|c|}{ MAINTENANCE COST OVER 10 YRS. FOR CASE 8} & $\$ 423,974.82$ \\
\hline & & \multicolumn{2}{|c|}{ TOTAL COST FOR CASE 8} & $\$ 640,634.91$ \\
\hline
\end{tabular}


Table 15.47 Case 9 Total Cost by Subcatchment

\begin{tabular}{|c|c|c|c|c|}
\hline SUBCATCHMENT & LID BMPs & $\begin{array}{c}\text { CAPITAL } \\
\text { FACILITY COST }\end{array}$ & $\begin{array}{l}\text { MAINTENANCE } \\
\text { COST } \\
\text { OVER } 10 \text { YRS. }\end{array}$ & TOTAL COST \\
\hline S5 & Bioretention Pond & $\$ 24,533.52$ & $66,396.52$ & $\$ 90,930.04$ \\
\hline S5 & Infiltration Trench & $\$ \quad 21,380.51$ & $36,560.89$ & $\$ 57,941.40$ \\
\hline S6 & Infiltration Trench & $\$ \quad 14,032.27$ & $23,995.33$ & $\$ 38,027.61$ \\
\hline S6 & Bioretention Pond & $\$ 16,101.66$ & $43,576.89$ & $\$ 59,678.55$ \\
\hline S7 & Vegetative Swale & $4,361.30$ & $8,574.82$ & $\$ 12,936.12$ \\
\hline S8 & Bioretention Pond & $6,338.85$ & $17,155.20$ & $\$ 23,494.05$ \\
\hline S8 & Infiltration Trench & $5,524.22$ & $9,446.47$ & $\$ 14,970.69$ \\
\hline S9 & Bioretention Pond & $7,801.34$ & $21,113.23$ & $\$ 28,914.56$ \\
\hline S9 & Infiltration Trench & $6,798.62$ & $11,625.71$ & $\$ 18,424.34$ \\
\hline S10 & Infiltration Trench & $\$ 31,262.01$ & $31,262.01$ & $\$ 62,524.02$ \\
\hline S11a & Bioretention Pond & $8,331.42$ & $22,547.83$ & $\$ 30,879.25$ \\
\hline S11a & Infiltration Trench & $7,260.71$ & $12,415.89$ & $\$ 19,676.60$ \\
\hline S11b & Infiltration Trench & $9,259.25$ & $15,833.42$ & $\$ 25,092.68$ \\
\hline S12a & Bioretention Pond & $\$ 16,900.36$ & $45,738.44$ & $\$ 62,638.80$ \\
\hline S12a & Infiltration Trench & 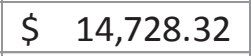 & $25,185.58$ & $\$ 39,913.90$ \\
\hline$S 12 b$ & Infiltration Trench & $4,554.34$ & $7,787.97$ & $\$ 12,342.31$ \\
\hline S13 & Infiltration Trench & $1,107.64$ & $1,894.08$ & $\$ \quad 3,001.72$ \\
\hline S15 & Infiltration Trench & $2,589.46$ & $4,428.00$ & $\$ 7,017.46$ \\
\hline S16 & Infiltration Trench & $7,451.81$ & $12,742.68$ & $\$ 20,194.49$ \\
\hline S17 & Infiltration Trench & $3,209.89$ & $5,488.95$ & $\$ \quad 8,698.84$ \\
\hline S18 & Infiltration Trench & $\$ 11,957.99$ & $20,448.28$ & $\$ 32,406.27$ \\
\hline S19 & Infiltration Trench & $2,415.32$ & $4,130.22$ & $\$ \quad 6,545.53$ \\
\hline S20 & Infiltration Trench & $6,358.16$ & $10,872.51$ & $\$ 17,230.67$ \\
\hline S21 & Infiltration Trench & $8,364.34$ & $14,303.10$ & $\$ 22,667.44$ \\
\hline S22 & Infiltration Trench & $\$ 10,459.47$ & $17,885.80$ & $\$ 28,345.27$ \\
\hline S23 & Bioretention Pond & $\$ 10,399.67$ & $28,145.25$ & $\$ 38,544.92$ \\
\hline \multirow[t]{4}{*}{ S24 } & Vegetative Swale & $7,047.84$ & $13,856.87$ & $\$ 20,904.71$ \\
\hline & \multicolumn{3}{|c|}{ CAPITAL FACILITY COST FOR CASE 9} & $\$ 270,530.29$ \\
\hline & \multicolumn{3}{|c|}{ MAINTENANCE COST OVER 10 YRS. FOR CASE 9} & $\$ 533,411.95$ \\
\hline & & \multicolumn{2}{|c|}{ TOTAL COST FOR CASE 9} & $\$ 803,942.24$ \\
\hline
\end{tabular}


Table 15.48 Case 10 Total Cost by Subcatchment

\begin{tabular}{|c|c|c|c|c|}
\hline SUBCATCHMENT & LID BMPs & $\begin{array}{c}\text { CAPITAL } \\
\text { FACILITY COST }\end{array}$ & $\begin{array}{l}\text { MAINTENANCE } \\
\text { COST } \\
\text { OVER } 10 \text { YRS. }\end{array}$ & TOTAL COST \\
\hline S1 & Infiltration Trench & $\$ 22,337.96$ & $38,198.14$ & $\$ 60,536.10$ \\
\hline S2 & Infiltration Trench & $6,732.59$ & $11,512.80$ & $\$ 18,245.39$ \\
\hline S4 & Infiltration Trench & $\$ 10,229.27$ & $17,492.15$ & $\$ 27,721.42$ \\
\hline S4 & Bioretention Pond & $\$ 10,229.27$ & $17,492.15$ & $\$ 27,721.42$ \\
\hline S5 & Bioretention Pond & $\$ 24,533.52$ & $66,396.52$ & $\$ 90,930.04$ \\
\hline S5 & Infiltration Trench & $\$ 21,380.51$ & $36,560.89$ & $\$ 57,941.40$ \\
\hline S6 & Infiltration Trench & $\$ 14,032.27$ & $23,995.33$ & $\$ 38,027.61$ \\
\hline S6 & Bioretention Pond & $\$ 16,101.66$ & $43,576.89$ & $\$ 59,678.55$ \\
\hline S7 & Infiltration Trench & $4,857.56$ & $8,306.49$ & $\$ 13,164.05$ \\
\hline S8 & Bioretention Pond & $6,338.85$ & $17,155.20$ & $\$ 23,494.05$ \\
\hline S8 & Infiltration Trench & $5,524.22$ & $9,446.47$ & $\$ 14,970.69$ \\
\hline S9 & Bioretention Pond & $7,801.34$ & $21,113.23$ & $\$ 28,914.56$ \\
\hline S9 & Infiltration Trench & $6,798.62$ & $11,625.71$ & $\$ 18,424.34$ \\
\hline S10 & Infiltration Trench & $\$ 31,262.01$ & $31,262.01$ & $\$ 62,524.02$ \\
\hline S11a & Bioretention Pond & $8,331.42$ & $22,547.83$ & $\$ 30,879.25$ \\
\hline S11a & Infiltration Trench & $7,260.71$ & $12,415.89$ & $\$ 19,676.60$ \\
\hline S11b & Infiltration Trench & $9,259.25$ & $15,833.42$ & $\$ 25,092.68$ \\
\hline S12a & Bioretention Pond & $\$ 16,900.36$ & $45,738.44$ & $\$ 62,638.80$ \\
\hline S12a & Infiltration Trench & $\$ 14,728.32$ & $25,185.58$ & $\$ 39,913.90$ \\
\hline $\mathrm{S} 12 \mathrm{~b}$ & Infiltration Trench & $4,554.34$ & $7,787.97$ & $\$ 12,342.31$ \\
\hline S13 & Infiltration Trench & $1,107.64$ & $1,894.08$ & $\$ \quad 3,001.72$ \\
\hline S15 & Infiltration Trench & $2,589.46$ & $4,428.00$ & $\$ 7,017.46$ \\
\hline S16 & Infiltration Trench & $7,451.81$ & $12,742.68$ & $\$ 20,194.49$ \\
\hline S17 & Infiltration Trench & $3,209.89$ & $5,488.95$ & $\$ \quad 8,698.84$ \\
\hline S18 & Infiltration Trench & $\$ \quad 11,957.99$ & $20,448.28$ & $\$ 32,406.27$ \\
\hline S19 & Infiltration Trench & $2,415.32$ & $4,130.22$ & $\$ \quad 6,545.53$ \\
\hline S20 & Infiltration Trench & $6,358.16$ & $10,872.51$ & $\$ 17,230.67$ \\
\hline S21 & Infiltration Trench & $8,364.34$ & $14,303.10$ & $\$ 22,667.44$ \\
\hline S22 & Infiltration Trench & $\$ 10,459.47$ & $17,885.80$ & $\$ 28,345.27$ \\
\hline S23 & Bioretention Pond & $\$ 10,399.67$ & $28,145.25$ & $\$ 38,544.92$ \\
\hline \multirow[t]{4}{*}{ S24 } & Vegetative Swale & $7,047.84$ & $13,856.87$ & $\$ 20,904.71$ \\
\hline & \multicolumn{3}{|c|}{ CAPITAL FACILITY COST FOR CASE 10} & $\$ 320,555.64$ \\
\hline & \multicolumn{3}{|c|}{ MAINTENANCE COST OVER 10 YRS. FOR CASE 10} & $\$ 617,838.85$ \\
\hline & & \multicolumn{2}{|c|}{ TOTAL COST FOR CASE 10} & $\$ 938,394.49$ \\
\hline
\end{tabular}




\subsection{Appendix I: Copyright Permissions}

Figures $4.1,5.1,10.2,10.3,10.4,10.5,11.1,11.3,11.4$ and 11.5 are from the author's personal digital archive and fall under the category of fair use.

Figures $9.1,10.1,12.1,12.2,12.3$ and 12.4 are in the public domain and not subject to copyright protection within the United States.

[END OF REPORT] 